Niger: Fifth Review Under the Three-Year Arrangement Under the Poverty Reduction and Growth Facility and Requests for Waiver, Modification of Performance Criteria, and Extension of the Arrangement-Staff Report; Staff Supplement; Press Release of the Executive Board Discussion; and Statement by the Executive Director for Niger

In the context of the fifth review under the three-year arrangement under the Poverty Reduction and Growth Facility and for Niger and Niger's requests for a waiver, modification of performance criteria, and extension of the arrangement, the following documents have been released and are included in this package:

- $\quad$ The staff report for the Fifth Review Under the Three-Year Arrangement Under the Poverty Reduction and Growth Facility and Requests for Waiver, Modification of Performance Criteria, and Extension of the Arrangement, prepared by a staff team of the IMF, following discussions that ended on September 18, 2007, with the officials of Niger on economic developments and policies. Based on information available at the time of these discussions, the staff report was completed on November 8, 2007. The views expressed in the staff report are those of the staff team and do not necessarily reflect the views of the Executive Board of the IMF.

- A staff supplement on the joint IMF/World Bank debt sustainability analysis.

- $\quad$ A Press Release summarizing the views of the Executive Board as expressed during its November 21, 2007 discussion of the staff report that completed the review.

- $\quad$ A statement by the Executive Director for Niger.

The documents listed below have been or will be separately released.

Letter of Intent sent to the IMF by the authorities of Niger*

Memorandum of Economic and Financial Policies by the authorities of Niger*

Technical Memorandum of Understanding for 2007

*Also included in Staff Report

The policy of publication of staff reports and other documents allows for the deletion of market-sensitive information.

To assist the IMF in evaluating the publication policy, reader comments are invited and may be sent by e-mail to publicationpolicy@imf.org.

Copies of this report are available to the public from

International Monetary Fund • Publication Services

$70019^{\text {th }}$ Street, N.W. • Washington, D.C. 20431

Telephone: (202) 623-7430 • Telefax: (202) 623-7201

E-mail: publications@imf.org • Internet: http://www.imf.org

Price: $\$ 18.00$ a copy

International Monetary Fund

Washington, D.C. 

INTERNATIONAL MONETARY FUND

NIGER

\title{
Fifth Review Under the Three-Year Arrangement Under the Poverty Reduction and Growth Facility and Requests for Waiver, Modification of Performance Criteria, and Extension of the Arrangement
}

\author{
Prepared by the African Department \\ (In consultation with other departments) \\ Approved by Jean A. P. Clément and Anthony Boote
}

November 8, 2007

Main issues: Overall performance under the Poverty Reduction and Growth Facility (PRGF)
supported program was satisfactory. All but one performance criterion through end-September 2007
were observed. All but one benchmark through September 2007 were met. The staff recommends
completion of the review. The authorities request the extension of the arrangement to May $31,2008$.
Recent developments: Good harvests in 2006 and 2007 have improved food security and eased
inflation. The outlook for end-2007 and 2008 is positive, although the security concerns in the North
are a risk factor. Economic growth is expected to remain robust and inflation low. A new strategy for
growth acceleration and poverty reduction for 2008-12 has been prepared. A donor conference was
held on October 25-26 in Brussels.
The mission and participants: Discussions were held in Niamey September 5-18, 2007. The staff
team comprised Messrs. Sacerdoti (head), Callier, Salinas and Imam (all AFR). It was assisted by
Mr. Laporte, the Fund's Resident Representative in Niger, and liaised with the World Bank office in
Niamey. The staff team met with Mr. Zeine, Minister of Finance and Economy; Mr. Gagere,
National Director of the Central Bank of West African States (BCEAO); and other senior
government officials and donor representatives.
Past reviews: The PRGF arrangement (SDR 6.58 million; 10 percent of quota) was approved by
Executive Directors in January 2005, and was augmented to 40 percent of quota (SDR 26.32 million)
in November 2005. The fourth review was completed in June 2007 . Disbursements to date amount to
SDR 24.44 million (37.1 percent of quota). The Fund in 2006 also approved debt relief amounting to
SDR 59.82 million (excluding Heavily-Indebted Poor Countries-HIPC-relief already committed)
under the Multilateral Debt Relief Initiative (MDRI).
Niger, a member of the West African Economic and Monetary Union (WAEMU), shares a
common fixed exchange rate and external tariffs with other members. The BCEAO conducts
monetary and exchange rate policies at the regional level. Relations with the Fund and the World
Bank are summarized in the Informational Annex. 


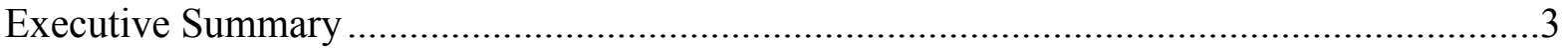

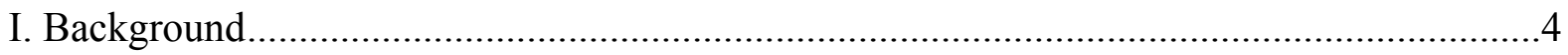

II. Recent Developments and Performance Under the Program.........................................4

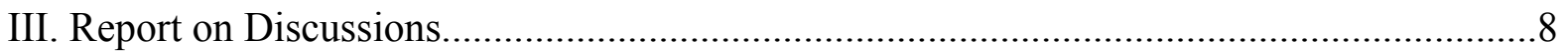

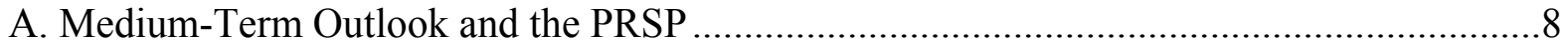

B. Macroeconomic Objectives and Policies for 2007-2008 ........................................ 9

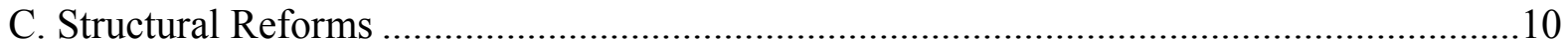

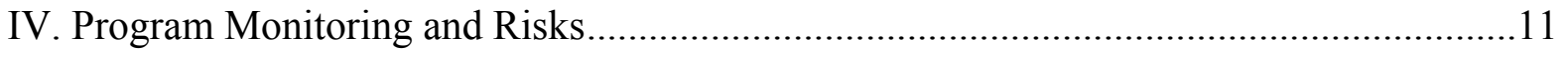

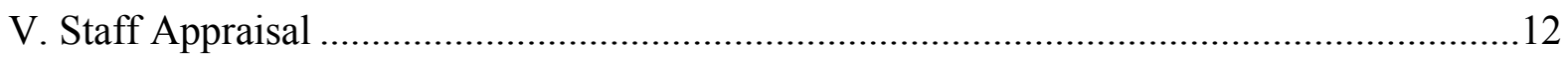

Figures

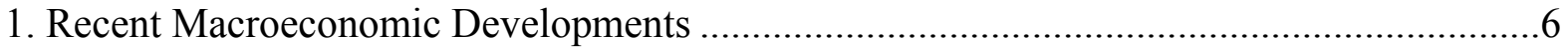

2. Main Features of the 2007 Program............................................................................

Tables

1. Proposed Schedule of Disbursements Under the PRGF Arrangement, 2007-08...............13

2. Selected Economic and Financial Indicators, 2005-10 ........................................... 14

3. Financial Operations of the Central Government, 2005-10 ..........................................15

4. Quarterly Financial Operations of the Central Government, 2007 .................................16

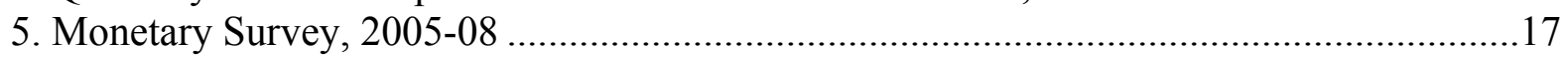

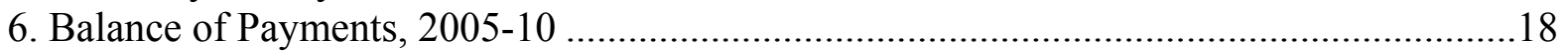

7. Actual and Projected Payments to the Fund, 2006-14 .................................................. 19

8. Budget Expenditure on Social and Rural Sectors, 2004-07.............................................20

9. Millennium Development Goals, 1997-2005 ...........................................................21

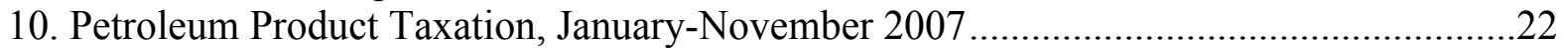

Appendix

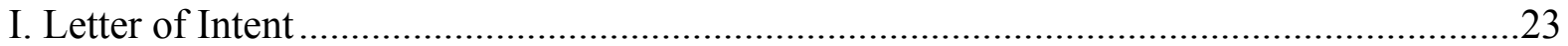

Attachment I. Memorandum of Economic and Financial Policies of the Government of Niger for 2007 ...........................................25

Attachment II. Technical Memorandum of Understanding for 2007 ...................35 


\section{Executive Summary}

- Macroeconomic performance in 2007 to September was positive. Growth prospects for the year are favorable, particularly because of strong agricultural production and buoyant investments. Inflation remains low. Growth prospects for the medium term have been improved by the rising price of uranium, which support continued exploration and development of existing mines, although insecurity in the northern mining areas, if not checked, could slow the expansion.

- The new Strategy for Accelerated Development and Poverty Reduction for 2008-12 has been finalized. The 2008 draft budget law is consistent with the new strategy.

- $\quad$ All performance criteria but one were met through end-September 2007. All quantitative targets and all but one structural benchmark through September were met.

- $\quad$ The 2007 fiscal program has been modified to take into account (i) a shortfall in external budget support (estimated at 0.8 percent of GDP for 2007 as a whole); (ii) additional revenues in the form of expected exceptional dividends and licenses from mining companies; and (iii) additional expenditures aimed at restoring security in the Northern region. Overall, the basic fiscal deficit would be lower than programmed at the time of the Fourth Review (IMF Country Report CR/07/261), though domestic financing would be slightly higher. The program includes reforms to enhance tax administration and public expenditure management.

- The authorities are also pursuing reforms to improve the investment climate, including privatization of a government-controlled bank, and revitalization of the microfinance institutions with a stronger regulatory framework.

- Given the strength of the program, and the corrective actions taken, staff supports the requested waiver, modifications of performance criteria, and completion of the fifth review. Staff also supports the requested extension of the arrangement to May 31, 2008 to allow completion of the sixth and final review on the basis of the December 2007 test date data. 


\section{BACKGROUND}

1. Niger is one of the poorest countries in the world. ${ }^{\mathbf{1}}$ The landlocked economy depends heavily on drought-prone subsistence agriculture, and has a low export base.

Despite prudent fiscal policies and efforts to bolster domestic revenue and strengthen public expenditure management, Niger is likely to require external support over the medium term. Together with sizable external assistance, prudent macroeconomic policies and improvements to the investment climate are critical if Niger is to attain higher economic growth and reduce poverty, as emphasized in the recently finalized Strategy for Accelerated Development and Poverty Reduction 2008-2012.

2. The political situation is stable, although an insurgency is festering in the uraniumrich northern area since early 2007. Parliamentary and presidential elections are planned for 2009.

\section{Recent Developments and Performance under the Program}

3. Overall macroeconomic performance was satisfactory in 2007

- At an estimated rate of 5.6 percent, real GDP growth in 2007 has been strong for the third year in a row since the drought-induced contraction of 2004. Good rains have strengthened agriculture and improved food security. Mining, telecommunications, and construction have also supported economic activity. Private investment, after its surge in 2005, remains above 15 percent of GDP (MEFP, paragraph 1, and Table 2 and Figure 1).

- Inflation remains very low. The real effective exchange rate (REER) depreciated modestly in the year to July 2007, as lower inflation than in trading partners more than offset the appreciation of the trade-weighted nominal exchange rate. The REER remains however about 8 percent above the 2000 level, as a result of the steady appreciation of the euro-pegged CFA franc. Despite this appreciation, an updated analysis of the equilibrium real exchange rate for Niger indicates that the REER is close to equilibrium, in view of the strong improvement of the terms of trade since 2000 .

- $\quad$ The estimated 2007 external current account deficit (excluding official grants) widened, in spite of the strong increase in the value of uranium exports, Niger's main export product. This deterioration reflected increases in mining-related imports and the replenishment of the stocks of petroleum products and cereal (Tables 2 and 6).

\footnotetext{
${ }^{1}$ Niger ranks last of 177 countries in the 2006 United Nations Human Development Index. Grants cover one third of 2007 central government expenditures.
} 
- $\quad$ Credit to the economy remained buoyant, despite the relatively high lending interest rates in real terms (Table 5). The situation of the banking system is sound, although nonperforming loans increased somewhat at end-June 2007, but are expected to be covered by higher provisions (MEFP, paragraph 3).

\section{Macroeconomic policy and reform implementation was broadly satisfactory}

- All quantitative performance criteria as well as the indicative targets through September 2007 were observed; all but one structural benchmark were met, although one partially and one with a small delay (MEFP, Table 2). One continuous structural performance criterion was breached.

- The performance criterion on the elimination of the tax deferment on petroleum products by July 2007 was not observed; the tax deferment was reduced in July and fully eliminated on November 1 . The government is requesting a waiver for the nonobservance of this criterion. Staff supports this request on the grounds that the delay was temporary, with the measure now having been taken; the program's fiscal objectives have not been undermined by the delay because of the ad valorem component of the petroleum tax regime (Table 10).

- $\quad$ The basic fiscal balance to June and to September 2007 was much better than programmed, with a significant surplus rather than a deficit (Text Table and Table 4). Revenue was somewhat higher than envisaged, while the authorities slowed expenditure because of shortfalls in external budgetary support. ${ }^{2}$

- $\quad$ Structural reforms advanced (MEFP, paragraphs 8 to 13). Public financial management reforms continued to focus on the strengthening of expenditure management and control (separation of the regulatory and accounting functions of the Treasury, reorganization of financial control and training of agents, appointment of staff to the new independent Audit Court (Cours des Comptes), effective establishment of the new General Directorate for Public Procurement) and the strengthening of the customs and tax directorates. In the financial sector, the tender for the Crédit du Niger (CDN) was launched. Revised mining and petroleum codes enhance transparency.

- $\quad$ The national security stock of cereal was strengthened, with donor support. Local grain purchases are also envisaged (MEFP, paragraph 7).

\footnotetext{
${ }^{2}$ The shortfall, amounting to a cumulative 0.7 percent of GDP at end-June and 0.9 percent of GDP at end-September, was mainly related to the suspension of the disbursements of budget support for the education sector, pending an agreement on appropriate modalities to safeguard the integrity of the use of these funds.
} 
Figure 1. Niger: Recent Macroeconomic Developments

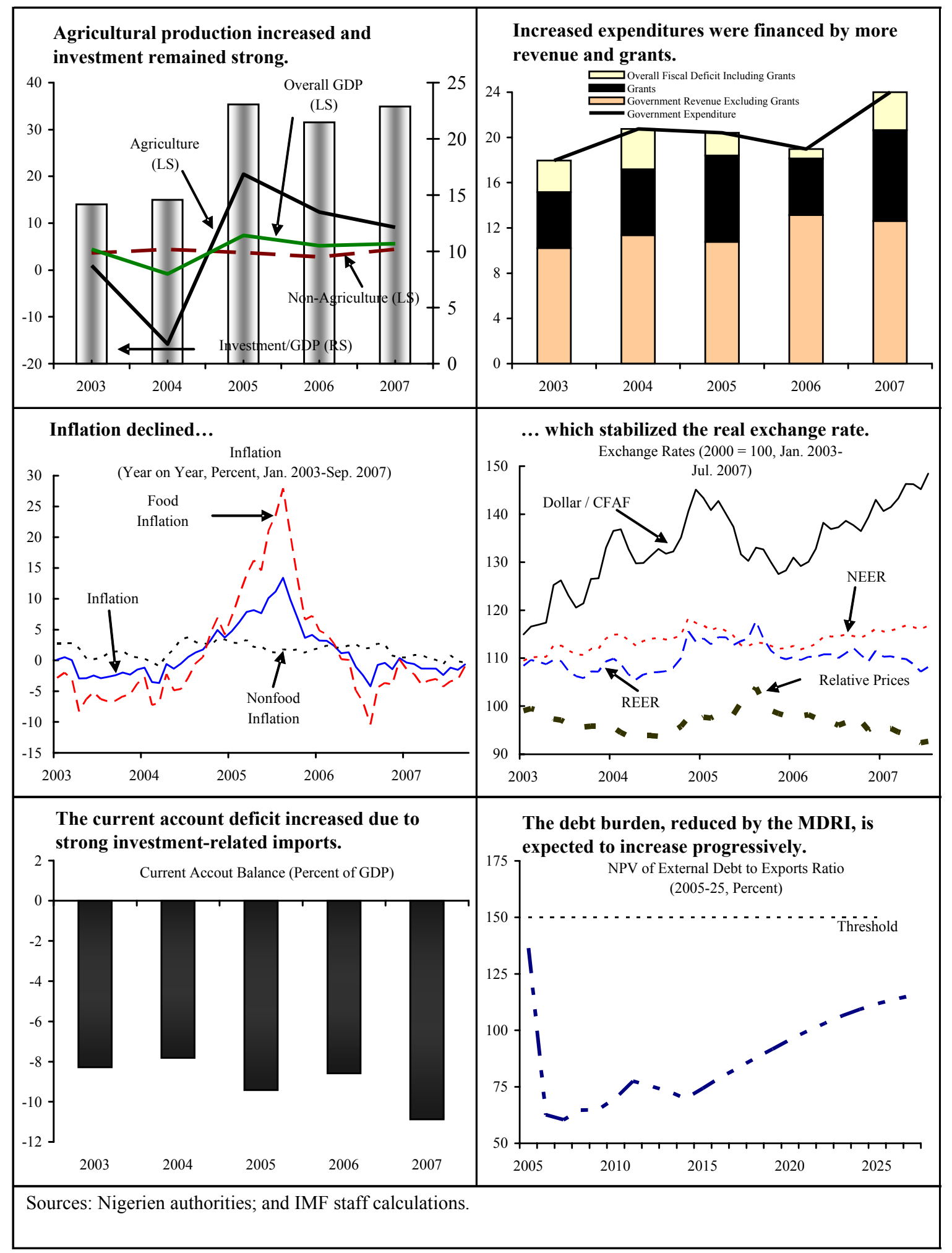



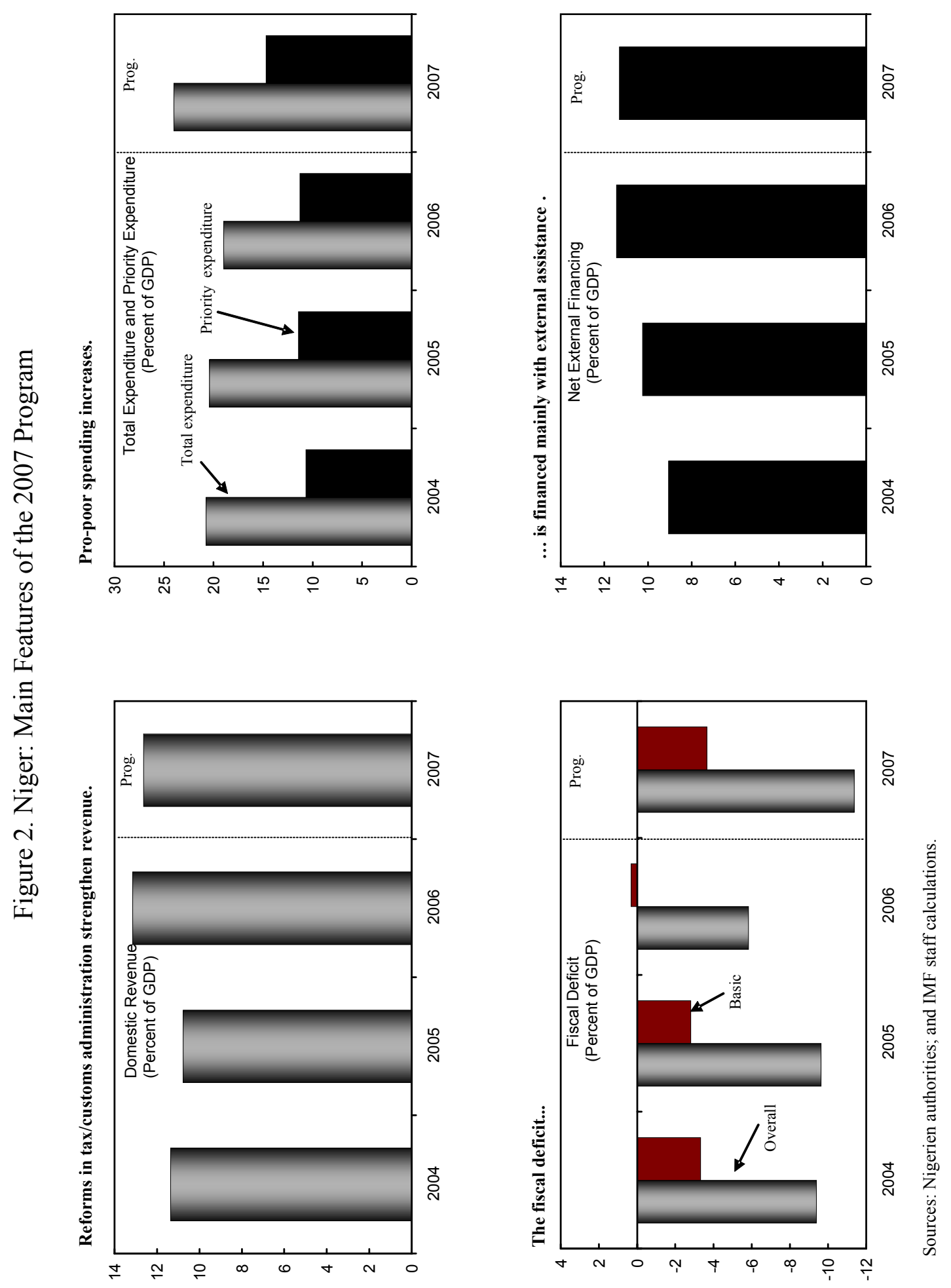
Government Financial Operations, 2006-07 (Percent of GDP)

\begin{tabular}{|c|c|c|c|c|c|}
\hline & \multirow{2}{*}{$\begin{array}{r}2006 \\
\text { Est. }\end{array}$} & \multirow[b]{2}{*}{$\mathrm{CR} / 07 / 261$} & \multicolumn{2}{|c|}{2007} & \multirow[b]{2}{*}{$\begin{array}{c}\text { Revised } \\
\text { Prog. }\end{array}$} \\
\hline & & & $\begin{array}{r}\text { Jan.-June } \\
\text { Est. }\end{array}$ & $\begin{array}{c}\text { Jan.-Sept. } \\
\text { Prov. Est. }\end{array}$ & \\
\hline Total revenue (excluding grants) & 13.1 & 11.5 & 6.3 & 9.3 & 12.6 \\
\hline Of which: tax revenue & 10.8 & 10.9 & 5.6 & 8.4 & 10.8 \\
\hline Total expenditure & 19.0 & 23.3 & 9.1 & 15.2 & 24.0 \\
\hline Of which: domestically financed & 12.8 & 15.6 & 6.2 & 9.9 & 16.3 \\
\hline Overall deficit (commitment) & -5.8 & -11.8 & -2.8 & -5.9 & -11.4 \\
\hline Basic Deficit/Surplus & 0.3 & -4.1 & 0.0 & -0.6 & -3.7 \\
\hline Change in payment arrears & -0.7 & -0.8 & -0.4 & -0.4 & -0.8 \\
\hline Overall deficit (cash) & -6.6 & -12.5 & -3.1 & -6.3 & -12.1 \\
\hline Financing & 6.6 & 12.5 & 3.1 & 6.3 & 12.1 \\
\hline External financing (net) & 11.4 & 12.2 & 3.8 & 7.4 & 11.3 \\
\hline Of which : Grants & 0.0 & 8.5 & 2.4 & 4.7 & 8.0 \\
\hline Domestic financing & -4.8 & 0.4 & -0.7 & -1.1 & 0.8 \\
\hline \multicolumn{6}{|l|}{ Memorandum item: } \\
\hline Nominal GDP (billions of CFAF) & 1,881 & 2,053 & 2,049 & 2,049 & 2,049 \\
\hline
\end{tabular}

Sources: Nigerien authorities; and IMF staff estimates.

\section{REPORT ON DISCUSSIONS}

5. The review discussions focused on (i) the budget outlook through end-year 2007; (ii) the macroeconomic framework for 2008; (iii) the new Strategy for Acceleration of Growth and Poverty Reduction (PRSP) 2008-2012; and (iv) structural reforms to public financial management, the financial sector, and the investment climate.

\section{A. Medium-Term Outlook and the PRSP}

\section{Strong uranium and other mining activities have improved the medium-term}

prospects. Increased investment in mining and related sectors (such as construction and transportation) and private sector-led expansion in agriculture for export should buoy growth, which could reach 6 percent in 2011-2012. The basic fiscal deficit is projected to remain low over the medium term thanks to increased mining receipts, notwithstanding a strong increase in high priority spending and recurrent costs related to higher government investment. Strong growth, however, is predicated on security being maintained in the northern mining region.

\section{The new PRSP for 2008-12 describes policies and reforms to bolster economic} growth and make progress toward the MDGs. The strategy aims to preserve macroeconomic stability, increase public investment in human capital and physical infrastructure, strengthen economic governance, and develop the private sector. The PRSP includes three scenarios: (i) a base case scenario, consistent with staff's current medium-term framework; (ii) an intermediate scenario, which envisages expenditures 20 percent higher than in the current medium-term framework over the 5-year period; and (iii) an "MDG 
scenario," which puts aggregate expenditures 86 percent higher than in the base case. A joint staff advisory note (JSAN) for the new PRSP is being finalized. The staff's medium-term projections could be revised in the context of a possible successor arrangement under the PRGF, in the event that external support for Niger's new PRSP for 2008-12 is scaled up. The results of the donor conference on October 25-26 indicate that the support announced by donors is broadly in line with the intermediate PRSP scenario.

\section{Under the latest Debt Sustainability Analysis (DSA), external debt indicators} over the long run remain below the policy-based thresholds, and the debt burden is projected to increase only gradually over time (Supplement I). The staff assessment is that Niger remains at moderate risk of debt distress, given the prospect of faster export growth and assuming that new borrowing continues to be made at very concessional terms. The main assumptions for the medium term are an average annual growth of GDP of 5 percent, and of export volume of 5 percent after 2016, following a more rapid growth in the years before 2016 because of development of new uranium mines. Sensitivity tests show that Niger's external debt burden would remain below thresholds under most of these scenarios.

However, the thresholds would be breached in the case of a temporary but strong reduction in export growth or in the case of a sizeable deterioration of the terms for new borrowing. The authorities plan to seek grants to finance a large part of the new investments, particularly under the scaling-up scenarios of the PRSP. The Debt Directorate at the Ministry of Finance and Economy is building its capacity to develop a medium-term debt strategy and analyze debt sustainability. Negotiations with remaining non-Paris Club creditors (Algeria, Iraq, Libya, and United Arab Emirates) for debt relief on terms comparable to those already obtained have not made progress.

\section{B. Macroeconomic Objectives and Policies for 2007-2008}

9. The authorities request some minor modifications to the 2007 fiscal program to take into account higher exceptional revenue from mining equivalent to 1.2 percent of GDP (Table 3). Even with additional domestically-financed expenditures ( 0.4 percent of GDP), mainly to exceptional security outlays, the basic fiscal deficit will be lower than originally programmed. Bank domestic financing will be slightly higher than initially targeted because of lower external budgetary assistance (MEFP, paragraphs 14-17 and Figure 2).

10. The Priority Investments Fund will be tapped to address security concerns in the North (MEFP, paragraph 16). The fund was established in 2007 to channel the exceptional mining receipts received in late 2006 (1.5 percent of 2007 GDP) towards priority expenditures related to security, rural development, infrastructure, and development support. Eighty percent of the receipts are expected to be used to strengthen military equipment.

11. The medium-term plan for the reduction of domestic arrears, finalized in April 2007 is being implemented. Domestic arrears have been cut by almost half between 1999 
and 2006, with the remaining stock equivalent to 7 percent of GDP. The bulk of the arrears is constituted by debts to the social security system, to suppliers, and to banks for advances made in the mid-1990s. Settlement of cross debt with two public utility companies are close to be finalized, and the payment of arrears towards private sector creditors has begun (MEFP, paragraph 18). Under the program for 2007, domestic arrears reduction is targeted at CFAF 15 billion (0.8 percent of GDP). In addition, the repayment of debt to the social security system under preparation (equivalent to 1.6 percent of GDP) will be made through issuance of Treasury paper, and settlement of arrears to banks ( 0.4 percent of GDP) is expected to be agreed soon. The residual amount, equivalent to about 4.2 percent of GDP, is expected to be repaid over a six year period; the precise timing and modalities are being negotiated with the different groups of creditors.

12. The macroeconomic outlook for $\mathbf{2 0 0 8}$ is favorable. Real GDP growth is projected at 5.4 percent, just below 2007 growth, fueled again by mining, construction, and transportation and telecommunication activities. Inflation is expected to remain low. The external current account deficit after grants is expected to contract by 0.2 percent of GDP (MEFP, paragraph 25).

13. The 2008 budget was submitted to the National Assembly in October 2007. The budget has a prudent expenditure stance and is likely to be complemented by a supplementary budget law, in order to allocate to priority outlays the proceeds of the exceptional dividends from uranium companies received in late 2007. The basic fiscal balance, including the expected outlays from the envisaged supplementary budget law, is expected to decrease to 2.8 percent of GDP on account of lower domestic capital expenditures. Tax revenue would increase by about 0.5 percent of GDP, although total revenue is expected to decline slightly as mining-related nontax revenues retreat from their exceptional level. Budget allocations to priority sectors are expected to increase and be consistent with the medium-term expenditure framework for these sectors (MEFP, paragraph 26). Overall bank credit to the government would increase only slightly, through the use of accumulated deposits at the central bank, leaving adequate room for credit to the private sector. Over the medium term, as indicated in the DSA, the government is expected to make only modest recourse to domestic financing.

\section{Structural Reforms}

\section{Public finance management}

\section{Because of the significant expenditure needs associated with the Millennium} Development Goals (MDGs), strengthening domestic revenue is a priority. Reforms are underway to buttress tax and customs administration and revamp the tax code (MEFP, paragraphs 19, 20 and 28).

15. The government is reinforcing public expenditure management in procurement, ex ante controls, and decentralized budget credits (crédits délégués) (MEFP, paragraph 21). 


\section{Reforms to Improve the Investment Climate}

16. The authorities are pursuing reforms to reduce the high cost of doing business, ${ }^{3}$ Beside past measures to reduce the cost of creating enterprises (MEFP, paragraph 13), the authorities have issued the call for tenders for the privatization of Crédit du Niger, and are moving forward with the restructuring of the financial branch of the post office and microfinance institutions (MEFP, paragraph 22). The start of operations of FINAPOSTE, the new bank to be created to take over the financial activities of the post office, will require more time than previously envisaged because of the need to inject additional public funds to ensure the soundness of the new institution. Operations are now expected to start in mid2008 under an action program agreed with the World Bank. Therefore, the establishment of modalities for reimbursing the frozen deposits (a performance criterion for end-December 2007 under the program) is now less urgent. The modalities will be defined in the coming months with World Bank assistance. The staff concurs with the request of the authorities to drop this performance criterion from the current program.

\section{The authorities are committed to abide to the principles of the Extractive} Industry Transparency Initiative (EITI), to which they were accepted as a candidate country in September 2007.

\section{Program Monitoring ANd Risks}

18. The authorities request a waiver for the nonobservance of one performance criterion as indicated in paragraph 4 . They also request (i) modification of the quantitative performance criterion on domestic financing of the government for end-December 2007 to allow for a slight increase in domestic financing (see paragraph 9); (ii) elimination of the structural performance criterion regarding frozen postal deposit under this program, reflecting the fact that the postal bank will be restructured in mid-2008 (see paragraph 16); (iii) modification of the structural performance criterion on the application of the rule-based pricing of petroleum products, to permit limited tax changes while establishing that the total tax per liter will not be reduced from the level of March 2007 (MEFP, paragraph 32, and TMU, paragraph 22), with which the staff concurs; and (iv) extension by four months of the current arrangement to allow for the completion of the sixth and final review on the basis of the December 2007 test date, which the staff considers appropriate.

19. Risks to the program are the relatively weak, though improving, revenue base, increased expenditure pressures, the possibility of adverse terms of trade shocks, and the security situation in the North.

\footnotetext{
3 The World Bank's Doing Business 2007 report ranked Niger 160 out of 175 countries in 2006, an improvement from 170 in 2005.
} 


\section{Staff Appraisal}

\section{Program performance thus far has been satisfactory with almost all}

performance criteria observed. Growth has been relatively strong over the last three years.

The authorities have reinforced public financial management, and carried out structural reforms to enhance the financial sector and spur private investment.

\section{The authorities' program continues to focus on strengthening revenue and} expenditure management. Timely measures to tighten controls, conduct tax audits, and curb exemptions are essential to achieve the revenue target. Pro-poor expenditures must also be safeguarded, as security outlays are increased. Staff welcomes the authorities' commitment to continue to strengthen expenditure management, procurement procedure, and budget controls.

22. Progress to enhance the investment climate should be accelerated. Judicial and land tenure reforms and efforts to further streamline the regulatory framework should take priority.

\section{The new PRSP provides a useful framework to mobilize resources, and allow} Niger to accelerate its progress towards the MDGs. External support should be provided mainly in the form of grants or highly concessional loans. The strategy also recognize the importance of strengthening domestic revenue and expenditure management to secure the objectives of the PRSP.

24. The staff welcomes Niger's acceptance as a candidate country to the EITI, and urges the country to move closer to compliance, given the large number of mining projects in the pipeline.

25. The risks to the program appear manageable. Niger's prudent expenditure management, revenue mobilization, and moderate external borrowing should reduce the risks associated with terms of trade shocks. Peaceful resolution of the conflict undermining security in the North is essential for sustained growth.

26. Given the strength of the program, and the corrective actions taken by the authorities, staff recommends Board approval of the authorities' request for a waiver for the nonobservance of one performance criterion, modification of performance criteria for the remainder of the period of the arrangement, and completion of the fifth review under the PRGF arrangement. It also supports the request for an extension of the arrangement to May 31, 2008. 
Table 1. Niger: Proposed Schedule of Disbursements Under the PRGF Arrangement, 2007-08

\begin{tabular}{lll}
\hline $\begin{array}{l}\text { Amount } \\
\text { (Millions) }\end{array}$ & Available date & Conditions Necessary for Disbursement ${ }^{1}$ \\
\hline SDR 0.940 & September 15, 2007 & $\begin{array}{l}\text { Observance of June 30,2007 and continuous } \\
\text { performance criteria, and completion of the fifth review } \\
\text { under the arrangement }\end{array}$ \\
SDR 0.940 & January 15, 2008 & $\begin{array}{l}\text { Observance of December 31, 2007 and continuous } \\
\text { performance criteria, and completion of the sixth } \\
\text { review under the arrangement }\end{array}$ \\
\hline
\end{tabular}
Source: International Monetary Fund.

${ }^{1}$ In addition to the generally-applicable conditions under the Poverty Reduction and Growth Facility arrangement. 
Table 2. Niger: Selected Economic and Financial Indicators, 2005-10

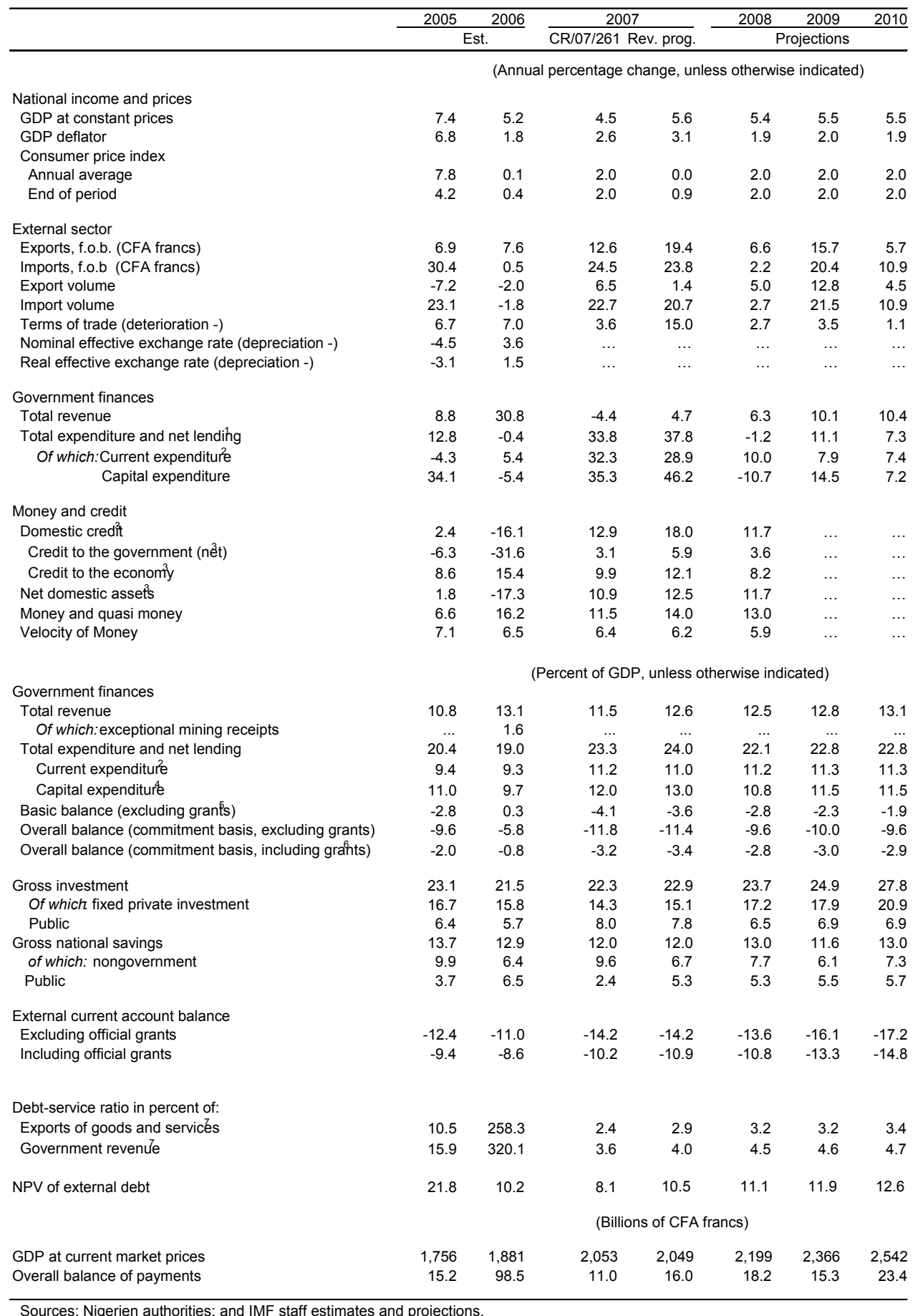

Sources. Nigerien authorities, and IMF staff estimates and projections.

${ }^{2}$ Including budget reserve.

${ }^{3}$ In percent of beginning-of-period money stock.

${ }^{4}$ Includes purchase of military equipment.

${ }^{5}$ Total revenue, excluding grants, minus total expenditure, excluding foreign-financed investment projects.

${ }^{6}$ Program Initiative data and projections include grants for projects. Actual data include budget grants.

${ }^{7}$ After HIPC and MDRI debt relief starting in 2006. 
Table 3. Niger: Financial Operations of the Central Government, 2005-10

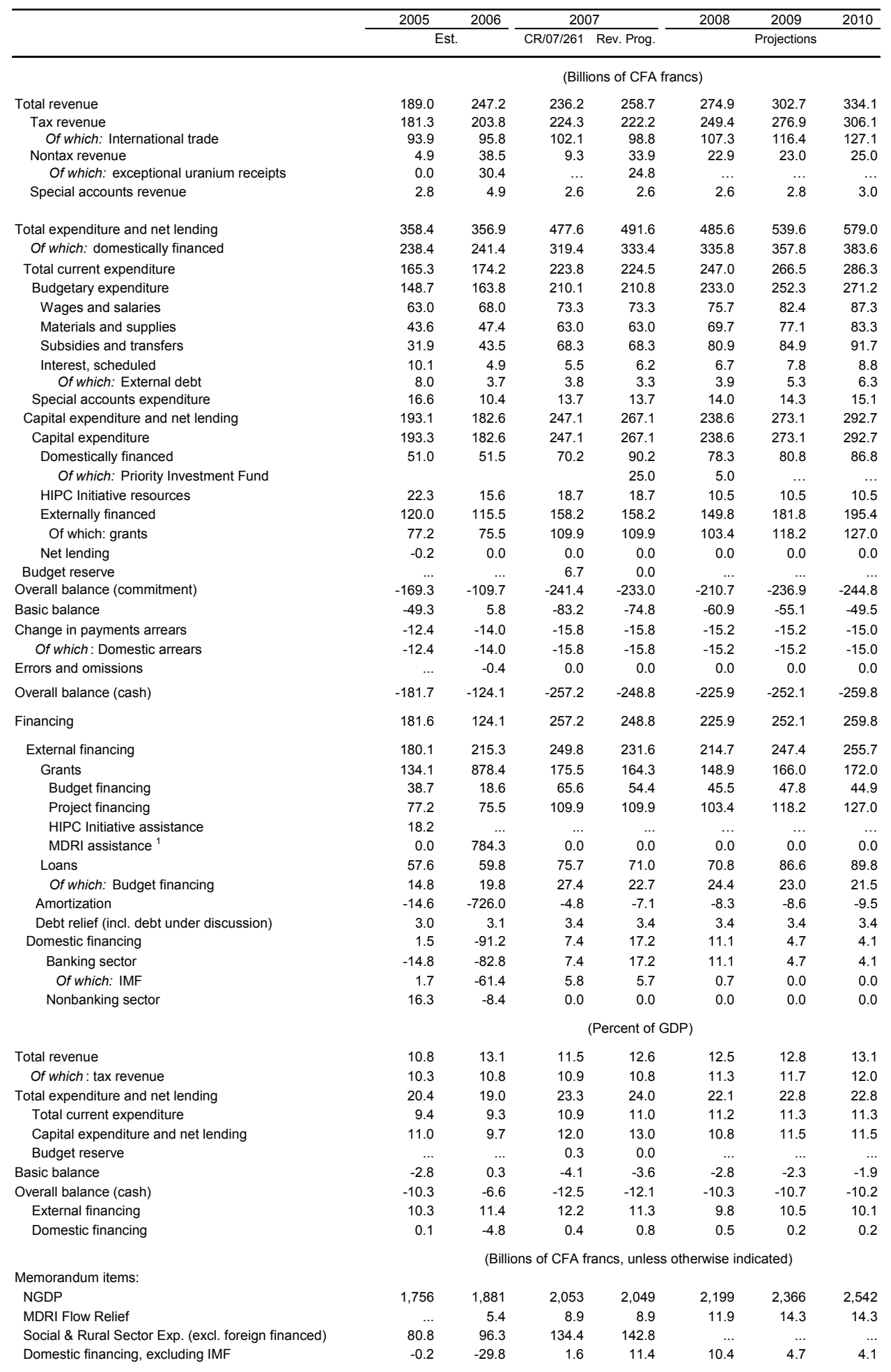

Sources: Nigerien authorities; and IMF staff estimates and projections.

${ }^{1}$ Multilateral Debt Relief Initiative stock-of-debt operation, including cancellation of debt treated under the HIPC Initiative, shown on accrual basis. Includes relief from IMF, World Bank, and African Development Bank. MDRI relief from the Fund is higher than in the balance of payments because of a valuation adjustment by the BCEAO. 
Table 4. Niger: Quarterly Financial Operations of the Central Government, 2007

\begin{tabular}{|c|c|c|c|c|c|c|c|c|}
\hline & \multicolumn{2}{|c|}{ Jan.-Mar 07} & \multicolumn{2}{|c|}{ Jan.-Jun. 07} & \multicolumn{2}{|c|}{ Jan.-Sep.07 } & \multicolumn{2}{|c|}{ Jan.-Dec. 07} \\
\hline & Prog. & Est. & Prog. & Est. & Prog. & Prov. Est. & Prog. & Rev.prog. \\
\hline & \multicolumn{8}{|c|}{ (Billions of CFA francs) } \\
\hline Total revenue & 56.2 & 59.8 & 112.7 & 128.3 & 170.2 & 190.7 & 236.2 & 258.7 \\
\hline Tax revenue & 54.3 & 57.8 & 108.1 & 113.8 & 162.3 & 171.4 & 224.3 & 222.2 \\
\hline International trade & 25.1 & 24.1 & 50.1 & 49.8 & 73.3 & 75.0 & 102.1 & 98.8 \\
\hline Goods and services & 13.2 & 15.8 & 29.2 & 34.6 & 45.5 & 52.6 & 60.7 & 64.0 \\
\hline Income & 12.8 & 14.3 & 22.7 & 24.3 & 34.0 & 35.7 & 47.2 & 45.5 \\
\hline Other & 3.2 & 3.6 & 6.1 & 5.1 & 9.5 & 8.1 & 14.3 & 13.9 \\
\hline Nontax revenue & 1.4 & 1.1 & 3.6 & 12.8 & 6.0 & 16.9 & 9.3 & 33.9 \\
\hline Special accounts revenue & 0.5 & 0.8 & 1.0 & 1.7 & 1.9 & 2.4 & 2.6 & 2.6 \\
\hline Total expenditure and net lending & 95.3 & 82.2 & 209.7 & 185.9 & 319.9 & 311.9 & 477.6 & 491.6 \\
\hline Of which: domestically financed & 70.1 & 56.4 & 155.2 & 127.5 & 232.8 & 203.6 & 319.4 & 333.4 \\
\hline Total current expenditure & 57.2 & 42.5 & 112.0 & 94.8 & 166.7 & 137.0 & 223.8 & 224.5 \\
\hline Budgetary expenditure & 53.0 & 41.8 & 105.5 & 91.4 & 156.7 & 130.3 & 210.1 & 210.8 \\
\hline Wages and salaries & 18.3 & 18.1 & 36.6 & 36.5 & 54.9 & 52.4 & 73.3 & 73.3 \\
\hline Materials and supplies & 15.7 & 9.9 & 31.8 & 20.1 & 47.6 & 39.2 & 63.0 & 63.0 \\
\hline Subsidies and transfers & 17.5 & 6.2 & 34.1 & 23.2 & 49.4 & 35.4 & 68.3 & 68.3 \\
\hline Interest, scheduled & 1.5 & 0.6 & 3.0 & 2.0 & 4.8 & 3.8 & 5.5 & 6.2 \\
\hline External debt & 0.9 & 0.6 & 1.8 & 1.8 & 2.8 & 2.8 & 3.8 & 3.3 \\
\hline Domestic debt & 0.6 & 0.0 & 1.2 & 0.2 & 2.0 & 1.0 & 1.7 & 3.0 \\
\hline Adjustments & 0.0 & 6.9 & 0.0 & 9.6 & 0.0 & -0.5 & 0.0 & 0.0 \\
\hline Special accounts expenditures & 4.2 & 0.7 & 6.5 & 3.4 & 10.0 & 6.7 & 13.7 & 13.7 \\
\hline Capital expenditure and net lending & 38.1 & 39.7 & 96.0 & 91.1 & 149.8 & 174.9 & 247.1 & 267.1 \\
\hline Capital expenditure & 38.1 & 39.7 & 96.0 & 91.1 & 149.8 & 174.9 & 247.1 & 267.1 \\
\hline Domestically financed & 9.7 & 10.9 & 32.0 & 24.6 & 47.0 & 56.1 & 70.2 & 90.2 \\
\hline HIPC Initiative resources & 3.2 & 3.0 & 9.5 & 8.0 & 15.7 & 10.5 & 18.7 & 18.7 \\
\hline Externally financed: grants & 15.4 & 19.6 & 31.2 & 42.1 & 48.2 & 76.0 & 109.9 & 109.9 \\
\hline Externally financed: loans & 9.8 & 6.1 & 23.3 & 16.3 & 38.9 & 32.3 & 48.3 & 48.3 \\
\hline Net lending & 0.0 & 0.0 & 0.0 & 0.0 & 0.0 & 0.0 & 0.0 & 0.0 \\
\hline Budgetary reserve & 0.0 & 0.0 & 1.7 & 0.0 & 3.4 & 0.0 & 6.7 & 0.0 \\
\hline Overall balance (commitment) & -39.2 & -22.4 & -97.1 & -57.6 & -149.7 & -121.2 & -241.4 & -233.0 \\
\hline Basic balance & -14.0 & 3.3 & -42.6 & 0.8 & -62.6 & -12.9 & -83.2 & -74.8 \\
\hline Change in payments arrears & -1.0 & -6.6 & -5.0 & -6.0 & -6.0 & -7.8 & -15.8 & -15.8 \\
\hline Domestic arrears & -1.0 & -6.6 & -5.0 & -8.6 & -6.0 & -8.3 & -15.8 & -15.8 \\
\hline Float (less than 120 days) & & 0.0 & & 2.6 & & 0.5 & & \\
\hline External arrears & & 0.0 & 0.0 & 0.0 & 0.0 & 0.0 & 0.0 & 0.0 \\
\hline Overall balance (cash) & -40.2 & -29.0 & -102.1 & -63.6 & -155.7 & -129.0 & -257.2 & -248.8 \\
\hline Financing & 40.2 & 29.0 & 102.1 & 63.6 & 155.7 & 128.5 & 257.2 & 248.8 \\
\hline External Financing & 42.8 & 45.9 & 89.1 & 78.0 & 144.3 & 151.1 & 249.8 & 231.6 \\
\hline Grants & 19.5 & 26.5 & 45.1 & 49.0 & 84.6 & 97.0 & 175.5 & 164.3 \\
\hline Budget financing & 4.1 & 6.9 & 13.9 & 6.9 & 36.4 & 21.0 & 65.6 & 54.4 \\
\hline Project financing & 15.4 & 19.6 & 31.2 & 42.1 & 48.2 & 76.0 & 109.9 & 109.9 \\
\hline Loans & 22.8 & 19.2 & 42.9 & 29.4 & 58.5 & 55.3 & 75.7 & 71.0 \\
\hline Budget financing & 13.0 & 13.1 & 19.6 & 13.1 & 19.6 & 23.1 & 27.4 & 22.7 \\
\hline Project financing & 9.8 & 6.1 & 23.3 & 16.3 & 38.9 & 32.3 & 48.3 & 48.3 \\
\hline Amortization & -1.3 & -1.1 & -2.6 & -2.2 & -3.9 & -3.9 & -4.8 & -7.1 \\
\hline Debt relief (incl. debt under discussion) & 0.9 & 1.3 & 1.7 & 1.8 & 2.6 & 2.7 & 3.4 & 3.4 \\
\hline Domestic financing & -2.6 & -16.9 & 13.0 & -14.3 & 11.5 & -22.6 & 7.4 & 17.2 \\
\hline Banking sector & -2.6 & -13.4 & 13.0 & -12.3 & 11.5 & -10.8 & 7.4 & 17.2 \\
\hline Of which: IMF & 4.4 & 4.4 & 5.1 & 5.1 & 5.1 & 5.1 & 5.8 & 5.7 \\
\hline Nonbanking sector & 0.0 & -3.5 & 0.0 & -2.1 & 0.0 & -11.8 & 0.0 & 0.0 \\
\hline
\end{tabular}

\footnotetext{
Sources: Nigerien authorities; and IMF staff estimates and projections.
} 
Table 5. Niger: Monetary Survey, 2005-08

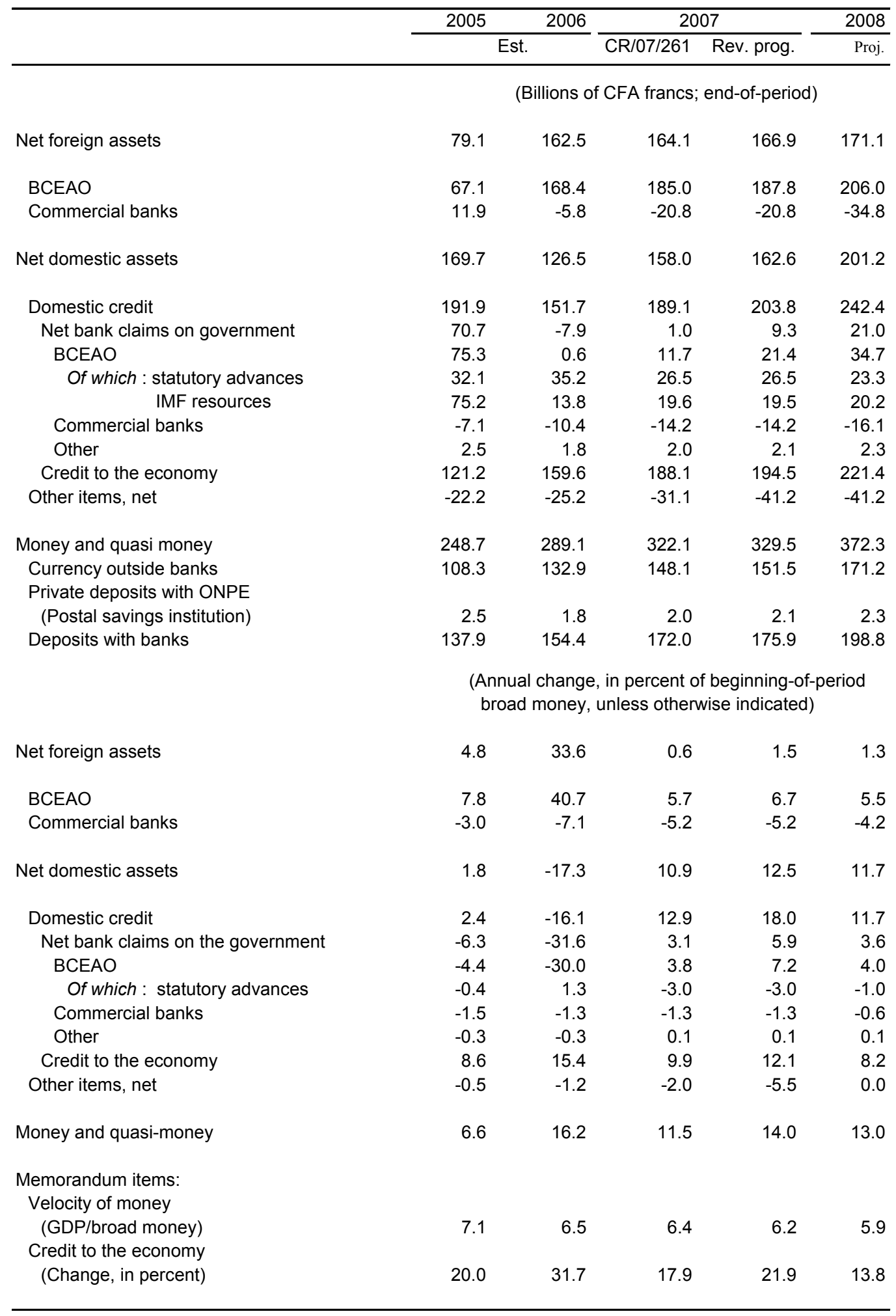

Sources: BCEAO; and IMF staff estimates and projections. 
Table 6. Niger: Balance of Payments, 2005-10

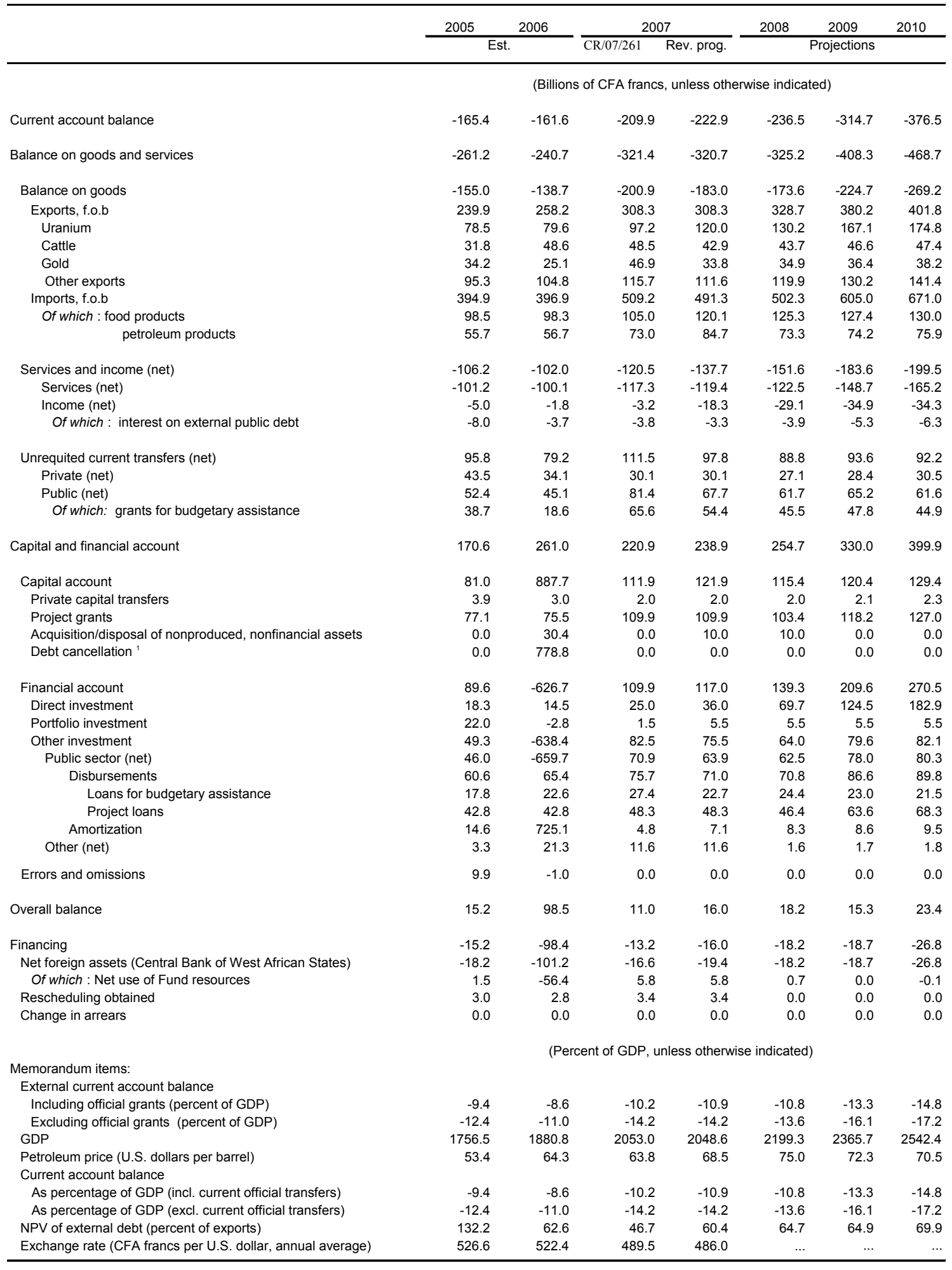

Sources: Nigerien authorities; and IMF staff estimates and projections.

${ }^{1}$ Multilateral Debt Relief Initiative stock-of-debt operation, including cancellation of debt treated under the enhanced HIPC initiative, on an accrual basis. 


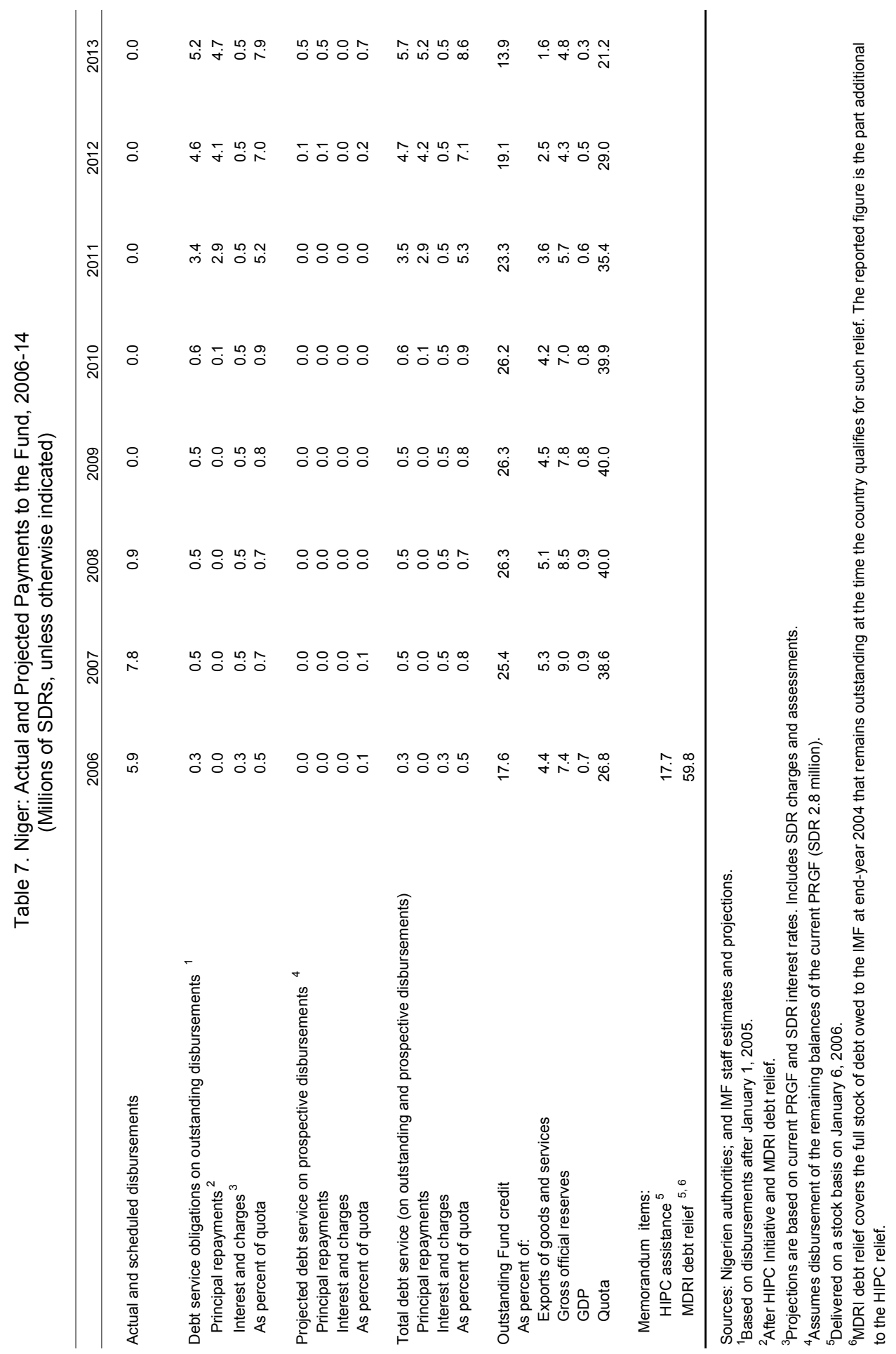


Table 8. Niger: Budget Expenditure on Social and Rural Sectors, 2004-07 (Millions of CFA francs)

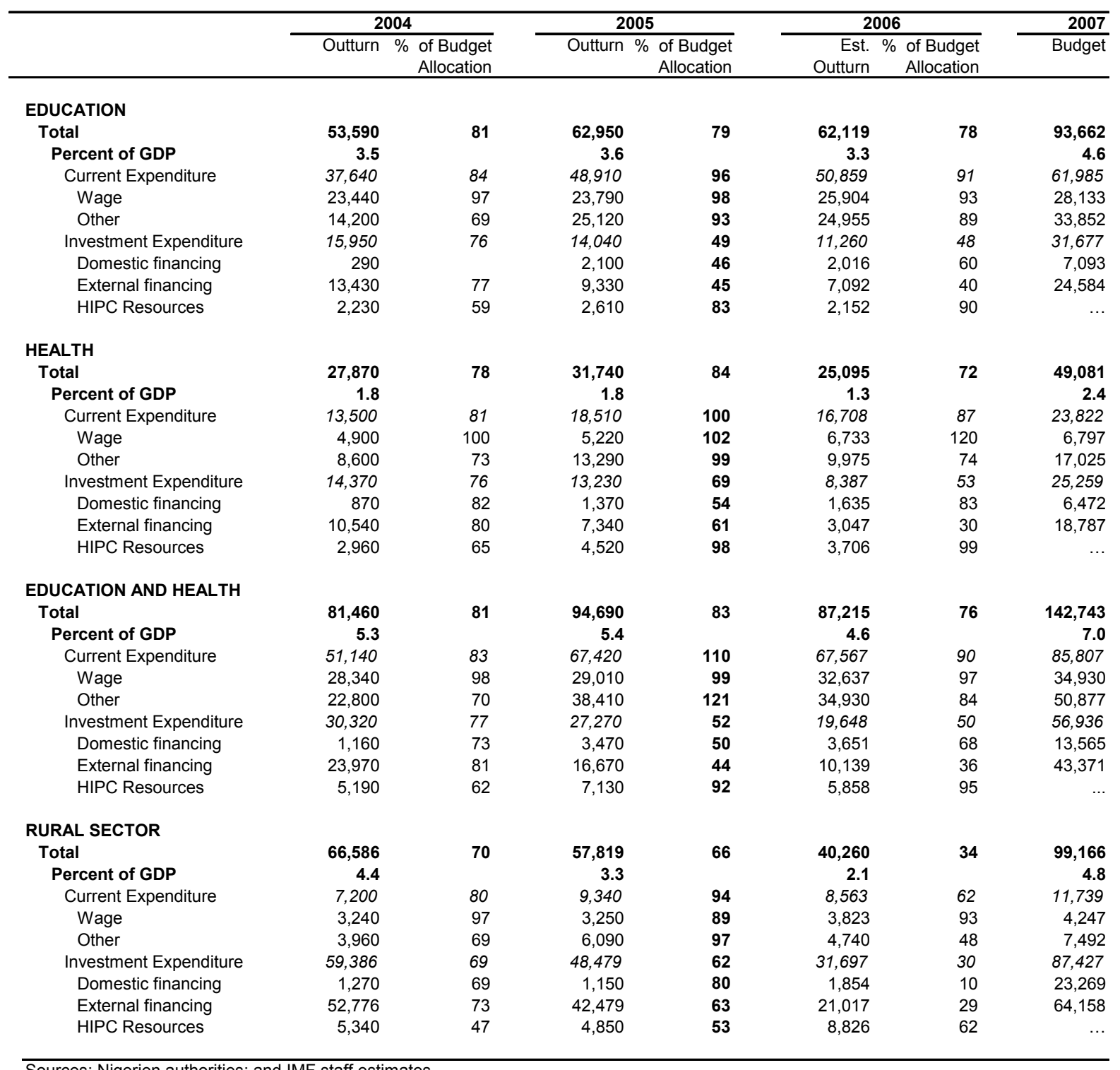

Sources: Nigerien authorities; and IMF staff estimates. 
Table 9. Niger: Millennium Development Goals, 1997-2005

\begin{tabular}{|c|c|c|c|c|c|}
\hline & 1997 & 2000 & 2003 & 2004 & 2005 \\
\hline \multicolumn{6}{|l|}{ Goal 1: Eradicate extreme poverty and hunger } \\
\hline Malnutrition prevalence, weight for age (\% of children under 5 ) & $\ldots$ & 40 & $\ldots$ & $\ldots$ & $\ldots$ \\
\hline Prevalence of undernourishment (\% of population) & 42 & $\ldots$ & 32 & 32 & $\ldots$ \\
\hline \multicolumn{6}{|l|}{ Goal 2: Achieve universal primary education } \\
\hline Literacy rate, youth total (\% of people ages $15-24$ ) & $\cdots$ & $\cdots$ & $\ldots$ & 37 & $\ldots$ \\
\hline Persistence to grade 5 , total (\% of cohort) & $\ldots$ & 74 & 74 & 74 & $\ldots$ \\
\hline Primary completion rate, total (\% of relevant age group) & 16.6 & 16.8 & 19 & 25 & 28.1 \\
\hline School enrollment, primary $(\%$ net $)$ & $\ldots$ & 25 & 36 & 39 & 39.9 \\
\hline \multicolumn{6}{|l|}{ Goal 3: Promote gender equality and empower women } \\
\hline Proportion of seats held by women in national parliament (\%) & $\cdots$ & 1 & 1 & 1 & 12.4 \\
\hline Ratio of girls to boys in primary and secondary education (\%) & $\ldots$ & 68.7 & 70.8 & 71.1 & 72.2 \\
\hline Ratio of young literate females to males (\% ages $15-24)$ & $\ldots$ & $\ldots$ & $\ldots$ & 44.2 & $\ldots$ \\
\hline Share of women employed in the nonagricultural sector ( $\%$ of total nonagricultural) & $\ldots$ & $\ldots$ & $\ldots$ & $\ldots$ & $\ldots$ \\
\hline \multicolumn{6}{|l|}{ Goal 4: Reduce child mortality } \\
\hline Immunization, measles ( $\%$ of children ages $12-23$ months) & 35 & 34 & 64 & 74 & 83 \\
\hline Mortality rate, infant (per 1,000 live births) & $\ldots$ & 159 & $\ldots$ & $\ldots$ & 81 \\
\hline Mortality rate, under-5 (per 1,000$)$ & $\ldots$ & 270 & $\ldots$ & $\ldots$ & 198 \\
\hline \multicolumn{6}{|l|}{ Goal 5: Improve maternal health } \\
\hline Births attended by skilled health staff ( $\%$ of total) & $\ldots$ & 15.7 & $\ldots$ & $\ldots$ & 17.2 \\
\hline Maternal mortality ratio (per 100,000 live births) & $\cdots$ & $\cdots$ & $\ldots$ & $\ldots$ & 648 \\
\hline \multicolumn{6}{|l|}{ Goal 6: Combat HIVIAIDS, malaria, and other diseases } \\
\hline Children orphaned by HIVIAIDS & $\ldots$ & $\ldots$ & 24,000 & 24,000 & $\ldots$ \\
\hline Contraceptive prevalence ( $\%$ of women ages $15-49$ ) & $\ldots$ & 14 & $\ldots$ & $\ldots$ & $\ldots$ \\
\hline Incidence of tuberculosis (per 100,000 people) & $\ldots$ & $\ldots$ & $\ldots$ & 157.4 & 163.6 \\
\hline Prevalence of HIV, total (\% of population ages $15-49$ ) & $\ldots$ & $\ldots$ & 1 & 1 & 1.1 \\
\hline Tuberculosis cases detected under DOTS (\%) & 19 & 34.3 & 49.8 & 45.5 & 49.6 \\
\hline \multicolumn{6}{|l|}{ Goal 7: Ensure environmental sustainability } \\
\hline $\mathrm{CO} 2$ emissions (metric tons per capita) & 0.1 & 0.1 & 0.1 & $\ldots$ & $\ldots$ \\
\hline Improved sanitation facilities (\% of population with access) & $\ldots$ & $\ldots$ & 12 & $\ldots$ & $\ldots$ \\
\hline Improved water source (\% of population with access) & $\ldots$ & $\ldots$ & 46 & $\ldots$ & 68.7 \\
\hline Nationally protected areas (\% of total land area) & $\ldots$ & $\ldots$ & 7.7 & 7.7 & $\ldots$ \\
\hline \multicolumn{6}{|l|}{ Goal 8: Develop a global partnership for development } \\
\hline Aid per capita (current US\$) & 31.3 & 17.9 & 35 & 39.7 & 36.9 \\
\hline Debt service (PPG and IMF only, \% of exports of G\&S, excl. workers' remittances) & 14 & 8 & 6 & 5 & 3.9 \\
\hline Fixed line and mobile phone subscribers (per 1,000 people) & 1.6 & 1.9 & 7.6 & 12.8 & 23.2 \\
\hline Internet users (per 1,000 people) & 0 & 0.3 & 1.5 & 1.8 & 2.1 \\
\hline Personal computers (per 1,000 people) & 0.2 & 0.4 & 0.6 & 0.7 & 0.7 \\
\hline Total debt service (\% of exports of goods, services and income) & 20 & 8 & 8 & 8 & $\ldots$ \\
\hline \multicolumn{6}{|l|}{ Other } \\
\hline Fertility rate, total (births per woman) & 8.2 & 8 & 7.8 & 7.7 & 7.7 \\
\hline GNI per capita, Atlas method (current US\$) & 180 & 160 & 180 & 210 & 240 \\
\hline GNI, Atlas method (current US\$) (billions) & 1.9 & 1.9 & 2.4 & 2.8 & 3.3 \\
\hline Gross capital formation (\% of GDP) & 10.9 & 11.4 & 14.2 & 15.9 & 18.5 \\
\hline Life expectancy at birth, total (years) & 42.7 & 43.6 & 44.5 & 44.7 & 44.9 \\
\hline Literacy rate, adult total (\% of people ages 15 and above) & $\ldots$ & $\ldots$ & $\ldots$ & 28.7 & $\ldots$ \\
\hline Population, total (millions) & 10.6 & 11.8 & 13.1 & 13.5 & 14 \\
\hline Trade (\% of GDP) & 40.4 & 43.5 & 41.2 & 41.7 & 39.3 \\
\hline
\end{tabular}

Sources: World Development Indicators database, April 2006, and Nigerien authorities. 
Table 10. Niger: Petroleum Product Taxation, January-November $2007^{1}$ (CFA francs per liter)

\begin{tabular}{|c|c|c|c|c|c|c|c|c|c|c|c|}
\hline & January & February & March & April & May & June & July & August & September & October & November \\
\hline \multicolumn{12}{|l|}{ Gasoline } \\
\hline Gross taxes & 183.44 & 181.80 & 180.10 & 186.14 & 196.15 & 206.26 & 209.75 & 207.17 & 202.21 & 199.66 & 200.44 \\
\hline Deferment & 0.00 & 0.00 & 0.00 & 34.00 & 30.00 & 69.09 & 43.50 & 43.84 & 23.38 & 12.88 & 0.00 \\
\hline Net taxes & 183.44 & 181.80 & 180.10 & 152.14 & 166.15 & 137.17 & 166.25 & 163.33 & 178.83 & 186.78 & 200.44 \\
\hline Difference from March & & & & -27.96 & -13.95 & -42.93 & -13.85 & -16.77 & -1.27 & 6.68 & 20.34 \\
\hline \multicolumn{12}{|l|}{ Diesel } \\
\hline Gross taxes & 137.59 & 132.01 & 132.25 & 134.17 & 139.19 & 143.08 & 144.49 & 147.94 & 149.30 & 151.96 & 154.75 \\
\hline Deferment & 0.00 & 0.00 & 0.00 & 17.00 & 0.00 & 15.02 & 0.00 & 13.08 & 18.68 & 29.60 & 0.00 \\
\hline Net taxes & 137.59 & 132.01 & 132.25 & 117.17 & 139.19 & 128.06 & 144.49 & 134.86 & 130.62 & 122.36 & 154.75 \\
\hline Difference from March & & & & -15.08 & 6.94 & -4.19 & 12.24 & 2.61 & -1.63 & -9.89 & 22.50 \\
\hline
\end{tabular}

Source: Nigerien authorities.

1/ Ad valorem customs duties, ad valorem value-added tax, and specific excise tax (CFAF 75 per liter of gasoline and CFAF 29 per liter of diesel). 


\title{
APPENDIX I \\ LETTER OF INTENT
}

Niamey, November 8, 2007

\author{
Mr. Dominique Strauss-Kahn \\ Managing Director \\ International Monetary Fund \\ Washington, D.C. 20431 \\ United States
}

Dear Mr. Strauss-Kahn:

1. The government continues to implement the policies and reforms envisaged under the PRGF-supported program. Through end-September 2007, all the performance criteria had been met, except for the criterion on the automatic flexible pricing system for petroleum products, since the tax deferral was not eliminated in July 2007, as indicated in the Memorandum of Economic and Financial Policies (MEFP) of May 16, 2007. We have eliminated the deferral on November 1.

2. Moreover, all the structural measures representing benchmarks through endSeptember 2007 were observed, with the exception of one.

3. Economic activity in 2007 was favorable, and GDP growth should benefit from a good year for farming, thanks to favorable rainfall; growth is also supported by activity in the mining, telecommunications, and construction sectors. Consumer prices have shown a downward trend so far through the year.

4. In the first half of the year, basic budgetary expenditure, excluding externally financed investment, remained below the program estimates, while revenue exceeded forecasts. Accordingly, the budget deficit and domestic financing were lower than envisaged in the program. These trends have continued in the third quarter.

5. The 2008 Budget Law is consistent with our poverty reduction strategy, containing larger budget appropriations for health, education, and rural development. The government is continuing to pursue reforms to strengthen revenue mobilization and introduce more rigorous management of expenditure, as well as to improve the banking and financial system, as indicated in the attached updated MEFP. The new Poverty Reduction Strategy Paper (PRSP) for 2008-12 has been finalized, and a donor meeting to mobilize funds in support of the PRSP convened in Brussels in late October.

6. The government of Niger requests the completion of the fifth review of the PRGFsupported program and a waiver for the above-mentioned structural performance criterion. It 
also requests modification of the quantitative criterion for end-2007 on domestic government financing (MEFP, paragraph 17), modification of the structural performance criterion on petroleum pricing (MEFP, paragraph 32), as well as elimination of the structural criterion for end-December 2007 regarding frozen postal deposits (MEFP, paragraph 22). As in the past, the government consents to the IMF's publication of this letter of intent, the MEFP, the technical memorandum of understanding, and the IMF staff report. The government considers that the policies set out in the attached MEFP are adequate to attain the objectives of the program. It will take any further measures that may become appropriate for this purpose. Niger will consult with the Fund on the adoption of such measures and in advance of revisions of the policies contained in the MEFP, in accordance with IMF policies on such consultation.

7. To allow for the completion of the sixth review, the government of Niger requests that the PRGF arrangement, which expires on January 30, 2008, be extended through endMay 2008.

Very truly yours, /s/

Ali Lamine Zeine

Minister of Economy and Finance

Attachments: Memorandum on Economic and Financial Policies

Technical Memorandum of Understanding 


\section{APPENDiX I-ATTACHMENT I \\ MEMORANDUM OF ECONOMIC AND FINANCIAL POLICIES OF THE GOVERNMENT OF NigER 2007-2008}

\section{ReCEnt DeVElopments ANd Program IMPlementation}

\section{Context and macroeconomic framework}

1. The economic and financial situation progressed favorably in the first part of 2007 and a good agricultural harvest is expected owing to favorable rainfall. According to the latest estimates, the growth in GDP may attain 5.6 percent in 2007, following a 5.2 percent growth in 2006. The increase in value-added in agriculture may reach 9 percent. Strong growth is expected in electricity, housing and public works, transport and telecommunication, supported by public and private investment. In mining, gold production has recorded an upturn with the reopening of the principal mine. As for uranium, a major investment program is in progress, in order to develop new deposits, replace depleted deposits, and upgrade equipment. On the basis of data for the first seven months of the year, inflation in 2007 (annual average) is expected to be close to zero.

2. Trends in the balance of payments in 2007 showed a strong increase in the value of uranium exports, reflecting the 58 percent revaluation of the export price. This has been accompanied by a strong increase in imports of capital goods, both for the mining sector and for infrastructure projects, in addition to the replenishment of the stocks of petroleum and grain products. Thus, the current account deficit is projected to rise from 8.6 percent of GDP in 2006 to 11 percent of GDP in 2007. External financing for projects is anticipated to rise appreciably, particularly in the grant component. The BCEAO's net foreign assets allocated to Niger may increase by about CFAF 19 billion.

3. The growth in bank credit in the first six months of the year has been substantial (10.5 percent) reflecting support for investments and coming in the aftermath of a 32 percent growth in 2006. These sustained rates of growth also reflect the recent opening of new banks. The money supply grew by 3.8 percent in the first six months of the year. In the second half of the year, credit to the economy is expected to expand further, and may attain 11 percent over the year, with growth in the money supply amounting to 14 percent. Non performing loans as a share of credit, net of provisions, increased to 11 percent at end-June 2007, but additional provisions are expected to be made.

\section{Fiscal policy}

4. In the first half of 2007, the government has pursued cautious macroeconomic policies and implemented key reforms to strengthen growth and reduce poverty. During this period, the basic fiscal deficit — which excludes externally financed capital expenditure — was 
limited to CFAF 11.7 billion (0.5 percent of the GDP forecast for 2007), much lower than the programmed CFAF 42.6 billion, on account of higher-than-anticipated revenues and weaker expenditure execution. On the revenue side, the profit tax and VAT yield surpassed expectations, while customs revenues were in line with forecasts. Nontax receipts were greater than anticipated, reflecting sizable revenue from the granting of a new mining concession (CFAF 9.8 billion, or 0.5 percent of GDP). With regard to expenditure, payment authorizations for goods and services and transfers and subsidies were well below forecasts.

5. All quantitative performance criteria under the program and the benchmarks for end-June 2007 under the PRGF have been observed, (Table 1). With the basic deficit far lower than programmed (quantitative indicator under the program), domestic financing (performance criterion) was well below programmed levels. Budget revenue, a quantitative indicator, substantially exceeded the objective.

6. All structural performance criteria and benchmarks through end-September were also met, except for the one pertaining to the petroleum product pricing mechanism (Table 2). The call for bids for the privatization of Crédit du Niger, scheduled for June 2007, was launched in September 2007. With respect to the petroleum product pricing mechanism, the tax deferment introduced in April 2007 was reduced in July and will be eliminated as soon as circumstances allow. As the deferment has been offset by the increase in the ad valorem component of petroleum taxation, the government is requesting a waiver for the nonobservance of this criterion.

7. The government's efforts, with donor support, strengthened the national grain security stock, which by end-August attained 65,000 tons, and grain banks were created. With the financial assistance anticipated for September and October, the security mechanism envisages grain purchases on local markets, which are well stocked, in order to raise the national security stock to its programmed level of 80,000 tons. Consideration is being given to increase the level of the security reserve to 110,000 tons.

\section{Reforms in public expenditure management and other sectors}

8. The government has continued to implement the recommendations of the PEMFAR (Public Expenditure Management and Fiscal Accountability Review) Program, which is supported by a number of technical and financial partners. In particular, with respect to expenditure management, the government has: (i) reorganized the structures of the Treasury with the separation of regulatory and accounting functions; (ii) strengthened the control system, through the adoption of texts reorganizing financial control and redefining its functions and the preparation of a manual of procedures; (iii) converted the accounts chamber of the Supreme Court into an independent Audit Court (Cour des Comptes), which is currently receiving technical assistance to define its procedures and train its staff; and (iv) made operational the new General Directorate for Control of Public Procurement, with the aim of strengthening mechanisms for the control and internal audit of government 
expenditure. However, as noted below, further efforts are still required in all these areas in order to make the supervisory mechanisms fully effective.

9. Concerning the regularization of the Treasury accounts, the opening balances for the fiscal years 1997-2005 were incorporated into the accounts of the Treasury's general balance sheet. The balances for 2006 are currently being prepared. For fiscal years prior to 1996, a draft law granting amnesty is being prepared. The budget review law (loi de règlement) for 2006 with the end-year Treasury accounts (comptes de gestion) will be submitted to the Audit Court and the National Assembly by end-2007.

10. The tax and customs administration is currently being strengthened, in accordance with the guidelines envisaged in the program. The Customs Evasion Enforcement Directorate has stepped up its controls over products benefiting from exemptions and temporary warehouses; the units carrying out the ex post verification of import valuations and exemptions at the major customs offices have been strengthened. The interconnection between the Torodi and Gaya border offices and the Niamey offices allows for more rigorous monitoring of customs clearance operations. The next step is to interconnect the main border offices with the regional customs offices; assistance from the EU has been requested for this purpose. The flow of information with the ports has been improved. At the General Directorate of Taxes (DGI), priority has been given to reducing the number of defaulting taxpayers, simplifying the procedures for the handling of disputed claims, improving tax controls through increased manpower and training, improving collection, and drafting procedure manuals.

11. Since the adoption of the new mining code in August 2006, over one hundred new research permits have been granted. The mining license agreements (conventions) follow the model agreement, which is annexed to the law. The decrees adopting the agreements are all published in the Official Journal. The National Mine Research Office (ONAREM) whose responsibilities include organizing mining exploration programs, has been replaced by two newly established entities, namely, the Geological and Mining Research Center and SOPAMIN; SOPAMIN holds the state's shares in the existing uranium companies previously held by the former ONAREM, and is intended to engage in commercial transactions such as uranium sales.

12. The new Petroleum Code was adopted in March 2007 and the implementing decree as well as the standard contracts were adopted in May 2007. The code envisages two types of regimes, concession and production-sharing agreements. No new permit has thus far been granted under the new code.

13. To improve the business climate, progress has been made in simplifying procedures and reducing the costs associated with the establishment of new businesses. Thus, since end-2006, the procedures for registration with the CNSS (National Social Security Fund) and the employment promotion agency have been unified, the payment of the global 
business license tax (patente synthétique) at the time of starting up a business is now deferred, the registration fee has been reduced by 5 points for certain sale contracts, and mandatory payment for enrollment in the Chamber of Commerce has been abolished.

\section{ECONOMiC ANd FinanCial Policies for the Remainder of 2007}

\section{Fiscal policy}

14. The budget program for the year 2007 has been revised to take account of (i) the updated forecast for external budget assistance; and (ii) the utilization of proceeds from the new mining permits, which have been allocated to the Priority Investment Fund (FIP). The FIP was created in May 2007 to carry out priority investment in the fields of security, rural development, infrastructure, and development support. Forecasts for external budget assistance have been revised downward, because disbursements related to assistance for the 10-Year Program of Development for Education have been delayed, given the need to define new procedures for monitoring the allocation of these resources. Furthermore, the African Development Bank assistance under a new structural adjustment loan is now expected for 2008. Thus, total external budgetary assistance is expected to amount to CFAF 77.1 billion in 2007 (3.8 percent of GDP), compared with the initial projection of CFAF 93 billion (4.5 percent of GDP).

15. Tax receipts are expected to turn out slightly below program projections; i.e., CFAF 222 billion for the year (10.8 percent of GDP), against an initial objective of CFAF 224.3 billion (10.9 percent of GDP). This shortfall reflects a decline in taxed imports, on account of increased trade flows with ECOWAS countries, which benefit from duty-free arrangements. Conversely, domestic tax receipts may surpass initial expectations (notwithstanding shortfalls in excise duties), in view of the favorable performance of the VAT and the increase in mining royalties. Nontax receipts (CFAF 33.9 billion, equivalent to 1.7 percent of GDP) should largely exceed initial projections, because of the new receipts linked to mining permits and of the exceptional dividends expected from mining companies (CFAF 15 billion).

16. On the expenditure side, we expect that current expenditures will be in line with original projections, while non FIP domestically financed investment are expected to stay below projections. FIP expenditures may attain CFAF 25 billion, mainly for security-related outlays. All in all, expenditures excluding externally funded investments should amount to CFAF 333.4 billion (16.3 percent of GDP), against the initial projection of CFAF 319.4 billion.

17. The basic fiscal deficit for 2007 is projected at CFAF 74.8 billion (3.6 percent of GDP), compared with the initially programmed figure of CFAF 83.2 billion (4.1 percent of GDP). Taking account of the anticipated reduction in domestic arrears of CFAF 15.1 billion, the basic fiscal deficit on a cash basis is expected to amount to CFAF 89.9 billion. Bank financing should exceed modestly initial program projections and 
reach CFAF 17.2 billion, or 0.8 percent of GDP (against CFAF 7.4 billion in the original program), because of the shortfall in external budget support.

18. Major progress is being made in the planned reduction of government domestic arrears, which have been identified by the working group in charge of evaluating domestic debt and arrears. In August 2005, the working group had prepared a preliminary report on changes over the period 1999-2004 in the arrears identified at end-1999. The data have been updated to end-December 2006. The action plan to reduce arrears has also been updated. Accordingly (i) cross-settlements with public utility companies (NIGELEC and SONITEL) for offsetting government debts and claims are close to be finalized; (ii) the settlement of arrears owed to private suppliers has begun; and (iii) frozen deposits of the former National Saving Bank (Caisse Nationale d'Épargne) will be paid back in the context of the entry into operation of the new postal bank (FINAPOSTE) scheduled for mid-2008.

\section{Structural reforms and financial sector reforms}

19. The revenue-collecting agencies (régies financières) will continue their efforts to control exemptions and combat fraud. A recruiting drive is in progress for both tax and customs directorates. The simplified taxation regime for taxpayers with turnover in the range of CFAF 30-100 million - which makes provision for quarterly rather than monthly tax returns - will be established in the Budget Law for 2008 (performance criterion). A new version of the General Tax Code is undergoing preparation, and will benefit from IMF advice.

20. With respect to mining taxation, the procedures for assessing the mining royalty will be strengthened, with a greater role to be given to Customs. DGI staff will be strengthened to monitor more precisely taxable profits of mining companies.

21. Ongoing efforts to strengthen financial supervision mechanisms will be vigorously pursued. Accordingly (i) the role of the General Directorate for Control of Government Procurement will be expanded, lowering the current threshold for which its approval for government contracts is required from CFAF 300 million to CFAF 100 million; its staff complement will be boosted to allow the entity to discharge its responsibilities effectively; (ii) training of financial controllers will be intensified with the finalization of the manual of procedures; (iii) government procurement divisions established at each ministry will have their staffing and quality standards enhanced; (iv) the public procurement code will be revised to allow full alignment with WAEMU rules; and (v) the management of delegated appropriations to regional units will be strengthened, through the upgrading of the IT system, with a view to improve monitoring of these appropriations and better verify compliance with the requisite procedures.

22. Reforms in the area of financial system restructuring will progress rapidly. Thus, with respect to FINAPOSTE, the licensing application is being finalized; it will be submitted to the BCEAO in the coming months. To restore the liquidity of the frozen saving 
deposits with the former National Saving Bank, the government transferred to FINAPOSTE CFAF 1 billion in February 2007; a further CFAF 1.4 billion will be disbursed before end-2007; the residual, amounting to CFAF 2.5 billion, will be settled in 2008 (CFAF 1.2 billion) and 2009 (CFAF 1.3 billion). To equilibrate the opening balance sheet of FINAPOSTE, the government is considering issuing non-tradable securities covering the gap between assets and liabilities. In addition, to provide FINAPOSTE with stable resources and allow it to meet prudential ratios, the government envisages depositing funds in a special capital account. The modalities for reimbursing the depositors of the former National Saving Bank will be defined after the license for FINAPOSTE has been issued. Therefore, the government requests the deletion of the performance criterion regarding the adoption before end-2007 of modalities for reimbursing these deposits.

23. In the microfinance sector, which faces numerous constraints, the microfinance regulation agency will commence operations shortly, and the government has made the planned contributions to two entities, Taimako and MCPEC (Mouvement des Caisses Populaires d'Epargne et de Crédit), while another entity, ADDACHE, has been put into liquidation.

\section{THE MACROECONOMIC FraMeWORK FOR 2008 AND THE 2008 BUDGET}

\section{The macroeconomic framework in the context of the 2008-12 strategy for accelerated development and poverty reduction}

24. The intermediate scenario of the new strategy for accelerated development and poverty reduction for the period 2008-12 envisages achieving an annual rate of growth of about 5.7 percent. A higher rate of growth - averaging 7 percent per year - is considered necessary in order to achieve the MDGs by 2015, but achieving it will require a very substantial increase in foreign aid. The strategy is predicated upon a diversified and sustainable growth, equitable access to social services, controlled population growth, strengthened social protection for vulnerable groups, development of infrastructure, and good governance. On October 25-26, a conference of technical and financial partners convened in Brussels to mobilize support for the new strategy.

25. For 2008, a cautious estimate of current trends indicates that the rate of growth in GDP in 2008 could reach about 5.4 percent, assuming normal rainfall. This growth would be attributable to a substantial increase in investment in mining and infrastructure. In the mining sector, uranium output could increase by about $3 \frac{1}{2}$ percent in response to current investment. The projected inflation rate is 2 percent. The external current account deficit is expected to hold steady at 11 percent of GDP; exports in value terms are projected to rise by 5.7 percent while imports could increase by around 3 percent, with a downturn in petroleum imports following the reconstitution of stocks in 2007; imports of capital goods and intermediate goods could increase by 9 percent. Net foreign assets of the BCEAO are 
projected to increase by about CFAF 18 billion, and the money supply is expected to increase by about 13 percent.

\section{Fiscal policy and public finance reforms}

26. Fiscal policy will be focused on making additional resources available to the priority sectors, in accordance with the medium-term expenditure frameworks for education, health, and rural development, while preserving debt sustainability. Thus, the basic fiscal deficit is expected to fall from CFAF 74.8 billion (3.6 percent of GDP) to CFAF 61 billion (2.8 percent of GDP). Budget revenues are anticipated to reach CFAF 275 billion or 12.5 percent of GDP, reflecting an upturn in the profit taxes paid by mining companies, and an increase in nontax receipts (particularly dividends of mining companies).

27. Total expenditures excluding externally financed projects is projected to decline from 16.3 percent of GDP in 2007 to 15.3 percent of GDP in 2008, with more sizable allocations for the social and rural development sectors. This amount takes into account the expenditures in the Budget Law for 2008, recently presented to the National Assembly, as well as additional expenditures that could be authorized in 2008 to use the exceptional dividends to be received before the end of 2007. Externally financed capital expendituresespecially grant-funded expenditures - will continue to increase, owing to efforts to expedite the implementation of such projects and improved monitoring.

28. On the revenue side, efforts to curb exemptions and to combat evasion will be continued. In customs, priority will be given to achieving electronic interconnection between the main border offices and regional customs offices, to allow for more rigorous monitoring of merchandise undergoing customs clearance. On-site customs controls will be better targeted. Supervision over the on-site use of exempt goods will be further strengthened. At the DGI, efforts will focus on: (i) simplifying VAT payment procedures for small and medium-sized enterprises; (ii) stepping up the surveys for taxpayers and enhancing tax supervision; (iii) integrating the tax assessment and tax collection functions inter alia through the adoption of a new software program; (iv) implementing an effective system for the refunding of VAT credits, particularly for exporters; and (v) establishing an improved information base for real estate and taxation, accompanied by a reduction in the real estate tax levied on formal sector economic agents.

29. Financing for the budget program for 2008 requires substantial donor support, not yet fully confirmed. With a programmed reduction in domestic arrears in the amount of CFAF 15.2 billion (0.8 percent of GDP), the basic deficit on a cash basis - excluding externally funded projects - is expected to amount to CFAF 51.9 billion (2.4 percent of GDP). External budget assistance is projected to amount to CFAF 70 billion on the basis of current estimates (particularly from the World Bank, the AfDB, the EU, France, and other bilateral partners). Domestic financing including IMF drawings is projected at CFAF 11.1 billion. 


\section{External debt management}

30. The government will pursue a cautious external debt management policy, following the substantial debt relief obtained under the Multilateral Debt Relief Initiative (MDRI). To ensure that this policy is implemented, the Public Debt Directorate of the Ministry of Economy and Finance has been strengthened. The Directorate's capacity to perform debt sustainability analysis has been enhanced through external technical assistance.

31. We will continue our efforts to reach debt relief agreements with non Paris Club members on comparable terms.

\section{Other structural measures}

32. With respect to retail prices of petroleum products, the government will continue to apply the monthly pricing mechanism in accordance with the provisions set forth in the August 2001 decree. The tax deferment was eliminated on November 1, 2007. In the period ahead the overall tax per liter in CFA francs will not decline from the level of March 2007. In the event of an emergency situation necessitating a review of this policy, the government will consult the Fund concerning the adoption of appropriate measures.

\section{Monitoring Program Execution}

33. Program monitoring will be based on continuous and semiannual quantitative performance criteria, structural performance criteria (including some continuous criteria), and quantitative and structural benchmarks (Tables 1 and 2). The performance criteria and benchmarks are defined in the Technical Memorandum of Understandings. Ceilings on domestic financing — net of the position with the IMF — will be adjusted to reflect the amounts by which external budgetary assistance (net of external debt service) has deviated from program projections. This should allow for the execution of the program of priority expenditures for poverty reduction and - in the event of a shortfall — to facilitate more rapid execution of this program (Table 1). In the event that external budgetary assistance falls short of program projections, the quarterly ceilings on domestic financing will be adjusted upward, to a maximum of CFAF 20 billion. In the event of an overrun, the ceiling on domestic financing will not be adjusted downward for the first CFAF 10 billion. The sixth program review will be completed before the expiration of the PRGF arrangement. 


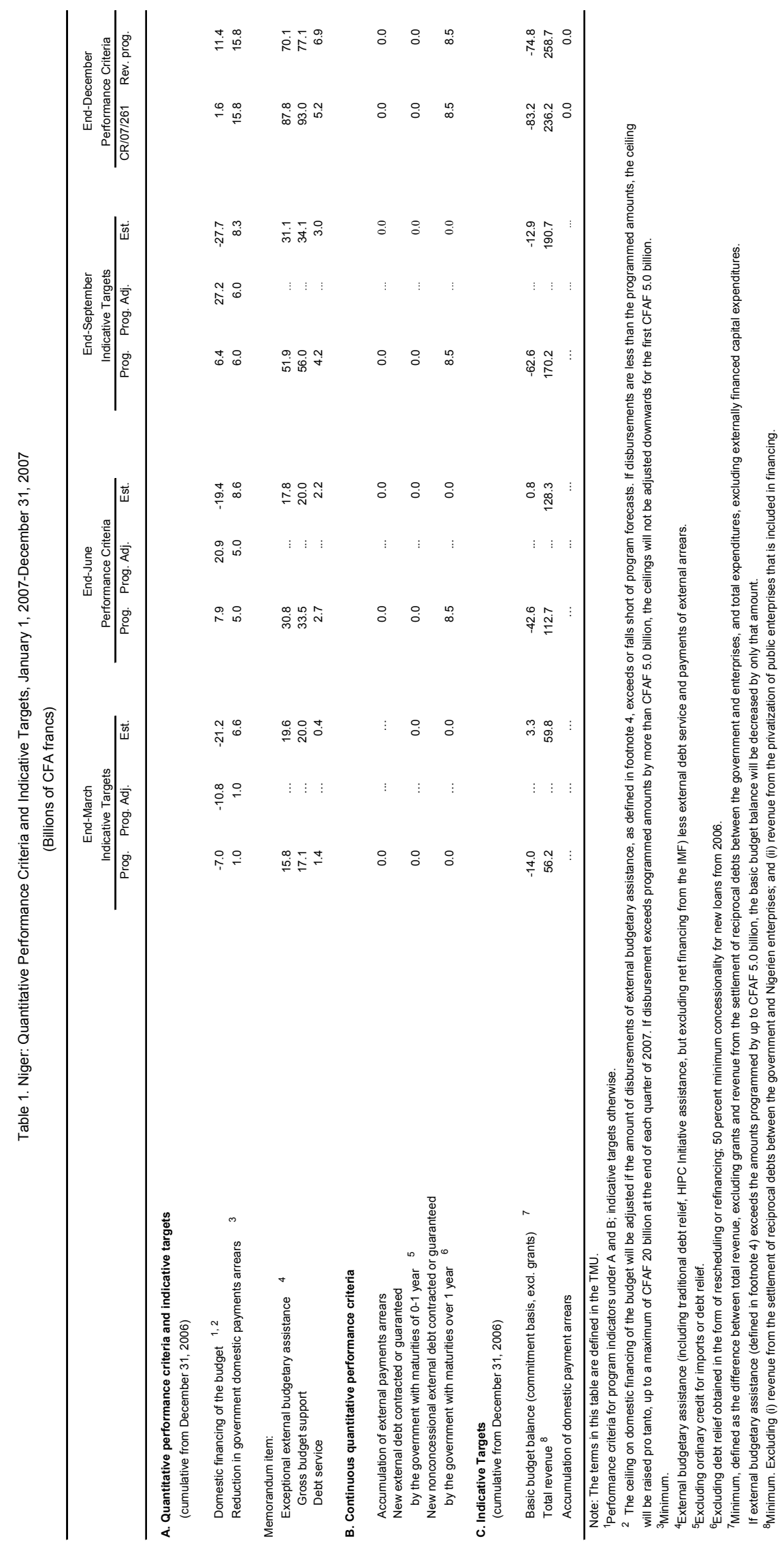


Table 2 . Structural Performance Criteria and Benchmarks under the January 2007-January 2008 Program

\begin{tabular}{|c|c|c|}
\hline Measures & Date & Status \\
\hline \multicolumn{3}{|l|}{ Structural performance criteria } \\
\hline $\begin{array}{l}\text { Apply the pricing system for petroleum products, adopted on August 1, 2001, with } \\
\text { no tax deferment after July } 1,2007 \text { (modified wording is included in paragraph } 22 \\
\text { of the Technical Memorandum of Understanding). }\end{array}$ & Continuous & $\begin{array}{l}\text { Not met in April- } \\
\text { October } 2007\end{array}$ \\
\hline $\begin{array}{l}\text { Adopt new monthly performance indicators for the main customs offices } \\
\text { and consistently track compliance with these indicators by producing monthly } \\
\text { implementation reports for submission to the IMF. }\end{array}$ & Continuous & Met \\
\hline $\begin{array}{l}\text { Establish the overall balance of the consolidated government accounts including } \\
\text { the interim balances from } 1997 \text { to December } 31,2002 .\end{array}$ & End-June 2007 & Met \\
\hline $\begin{array}{l}\text { Adopt a regulatory text establishing the modalities for repayment of frozen } \\
\text { savings deposits at the former National Savings Bank (Caisse Nationale } \\
\text { d'Epargne) over a two-year period (criterion dropped, see MEFP, paragraph 22). }\end{array}$ & $\begin{array}{l}\text { End-December } \\
2007\end{array}$ & $\begin{array}{l}\text { Criterion } \\
\text { dropped }\end{array}$ \\
\hline $\begin{array}{l}\text { Introduce a simplified tax regime with quarterly tax declarations for small- and } \\
\text { medium-sized enterprises to replace monthly declarations }\end{array}$ & $\begin{array}{l}\text { End-December } \\
2007\end{array}$ & \\
\hline \multicolumn{3}{|l|}{ Structural benchmarks } \\
\hline $\begin{array}{l}\text { Adopt the decree on the establishment of a regulatory agency for the } \\
\text { microfinance sector. }\end{array}$ & $\begin{array}{l}\text { End-December } \\
2006\end{array}$ & Met in April 2007 \\
\hline $\begin{array}{l}\text { Establish an action plan for the clearance of domestic arrears inventoried at end- } \\
1999\end{array}$ & $\begin{array}{l}\text { End-December } \\
2006\end{array}$ & Met in April 2007 \\
\hline $\begin{array}{l}\text { Disburse the annual universal service subsidy of CFAF } 380 \text { million to Niger Poste } \\
\text { for } 2006 \text { and } 2007\end{array}$ & $\begin{array}{l}\text { End-December } \\
2006 \text { and end- } \\
\text { December } 2007\end{array}$ & $\begin{array}{l}\text { Met in March } \\
2007\end{array}$ \\
\hline $\begin{array}{l}\text { Issue a call for bids for the privatization of Crédit du Niger to investors selected } \\
\text { following the call for expressions of interest. }\end{array}$ & $\begin{array}{l}\text { End-February } \\
2007\end{array}$ & $\begin{array}{l}\text { Met in } \\
\text { September } 2007\end{array}$ \\
\hline $\begin{array}{l}\text { Update the file of the large taxpayers unit (DGE) consistent with the turnover } \\
\text { threshold of CFAF } 100 \text { million }\end{array}$ & End-March 2007 & Met \\
\hline $\begin{array}{l}\text { Publish } 2006 \text { data on national budget execution and on expenditure execution } \\
\text { under the unified list of priority expenditures on a payment order basis. }\end{array}$ & End-March 2007 & $\begin{array}{l}\text { Partially met; } \\
\text { data available } \\
\text { but not published }\end{array}$ \\
\hline $\begin{array}{l}\text { Regularize Treasury depositors accounts that are in overdraft and close inactive } \\
\text { deposits accounts. }\end{array}$ & End-June 2007 & $\begin{array}{l}\text { Rescheduled for } \\
\text { end-December } \\
2007\end{array}$ \\
\hline $\begin{array}{l}\text { Provide for the adoption of the decree on the organization and mandate of the } \\
\text { Directorate General for Control of Public Procurement by the Council of Ministers }\end{array}$ & $\begin{array}{l}\text { End-December } \\
2007\end{array}$ & \\
\hline $\begin{array}{l}\text { Finalize compensation arrangements between the Treasury, NIGELEC, and } \\
\text { SONATEL }\end{array}$ & $\begin{array}{l}\text { End-December } \\
2007\end{array}$ & \\
\hline Finalize agreements for the settlement of Treasury arrears with banks & $\begin{array}{l}\text { End-December } \\
2007\end{array}$ & \\
\hline $\begin{array}{l}\text { Reduce the threshold for contracts requiring approval by the General Directorate } \\
\text { for Control of Public Procurement from CFAF } 300 \text { to CFAF } 100 \text { million }\end{array}$ & $\begin{array}{l}\text { End-December } \\
2007\end{array}$ & \\
\hline
\end{tabular}




\title{
APPENDIX I-ATTACHMENT II \\ TeChniCAl MEMORAndum OF Understanding
}

\begin{abstract}
Niamey, November 8, 2007
1. This technical memorandum of understanding defines the performance criteria and indicative targets for Niger's program under the Poverty Reduction and Growth Facility (PRGF) arrangement approved by the Executive Board on January 31, 2005 (CR/05/79). The performance criteria and indicative targets for end-December 2007 are set out in Table 1 of the government's Memorandum of Economic and Financial Policies (MEFP) dated November 8, 2007 and attached hereto. This technical memorandum of understanding also sets out the data-reporting requirements for monitoring the program.
\end{abstract}

\section{DEFINITION OF TERMS}

2. For the purpose of this technical memorandum, the following definitions of "debt," "government," "payments arrears," and "government obligations" will be used:

(a) As specified in point 9 of the Guidelines on Performance Criteria with Respect to Foreign Debt adopted by the Executive Board of the IMF on August 24, 2000 , debt will be understood to mean a current, that is, not contingent, liability, created under a contractual arrangement through the provision of value in the form of assets (including currency) or services, and which requires the obligor to make one or more payments in the form of assets (including currency) or services, according to a specific schedule; these payments will discharge the obligor of the principal and/or interest liabilities incurred under the contract. Debts can take a number of forms, the primary ones being as follows: (i) loans, that is, advances of money to the obligor by the lender made on the basis of an undertaking that the obligor will repay the funds in the future (including deposits, bonds, debentures, commercial loans, and buyers' credits) and temporary exchanges of assets that are equivalent to fully collateralized loans, under which the obligor is required to repay the funds, and usually pay interest, by repurchasing the collateral from the buyer in the future (such as repurchase agreements and official swap arrangements); (ii) suppliers' credits, that is, contracts where the supplier permits the obligor to defer payments until some time after the date on which the goods are delivered or services are provided; and (iii) leases, that is, arrangements under which property is provided that the lessee has the right to use for one or more specified period(s) of time that are usually shorter than the total expected service life of the property, while the lessor retains the title to the property. For the purpose of this guideline, the debt is the present value (at the inception of the lease) of all lease payments expected to be made during the period of the agreement, excluding those payments necessary for the operation, repair, or maintenance of the property. Under the definition of debt set out above, arrears, penalties, and judicially 
awarded damages arising from the failure to make payment under a contractual obligation that constitutes debt are debt. Failure to make payment on an obligation that is not considered debt under this definition (for example, payment on delivery) will not give rise to debt.

(b) Government refers to the central government of the Republic of Niger; it does not include any political subdivision, public entity, or central bank with a separate legal personality.

(c) External payments arrears are external payments due but not paid. Domestic payments arrears are domestic payments due but not paid, including reste a payer at the Treasury that are over 120 days overdue.

(d) Government obligation is any financial obligation of the government accepted as such by the government (including any government debt).

\section{Quantitative Performance Criteria}

\section{A. Net Domestic Financing of the Government}

\section{Definition}

3. Net domestic financing of the government is defined as the sum of (i) net bank credit to the government, as defined below; (ii) net nonbank domestic financing of the

Government, including government securities issued in CFA francs on the WAEMU regional financial market and not held by resident commercial banks, proceeds from the sale of government assets, and privatization receipts net of the cost of structural reforms to which these proceeds are earmarked.

4. Net bank credit to the government is equal to the balance of the government's claims and debts vis-à-vis national banking institutions. Government claims include cash holdings by the Nigerien Treasury, deposits with the central bank and commercial banks, and secured obligations. Government debt to the banking system includes debt vis-à-vis the central bank (excluding net financing from the IMF's Poverty Reduction and Growth Facility (PRGF), but including government securities) and to commercial banks (including government securities held by commercial banks), and deposits with the postal checking system.

5. The scope of the net bank credit to the government as defined by the BCEAO includes all central government administrations. The net bank credit to the government and the amounts of government treasury bills and bonds issued in CFA francs on the regional financial market of the WAEMU are calculated by the BCEAO, and the net nonbank financing of the government is calculated by the Nigerien Treasury, whose figures are those deemed valid within the context of the program. 
6. Nonbank net domestic financing includes: (i) the change in the amount of government bonds issued in the regional WAEMU market and not held by Niger's commercial banks; (ii) the change in the deposits of Treasury correspondents; (iii) the change in "comptes de consignations" at the Treasury.

7. The 2007 quarterly targets are based on the change in the level of stock between end-December 2006 and the date considered for the performance criterion or the indicative target.

\section{Adjustment}

8. The ceiling on net domestic financing will be subject to adjustments if disbursements of external budgetary support less external debt service and arrears payments, including disbursements under the PRGF, exceed or fall short of projected amounts. External budgetary support includes debt relief under the MDRI. For 2007, external budget support is calculated from end-December 2006.

9. In the event disbursements exceed projected budgetary assistance by up to a limit of CFAF 10 billion, the quarterly ceilings on net domestic financing will not be adjusted downward. If disbursements exceed programmed budgetary assistance by more than CFAF 10 billion, the ceilings on net domestic financing will be adjusted downward pro tanto by the amount of the excess disbursements beyond the CFAF 10 billion.

10. Conversely, in the event disbursements fall short of projected external budgetary assistance for each end of quarter in 2007, the corresponding quarterly ceilings on net domestic financing will be raised pro tanto, up to a maximum of CFAF 20 billion.

\section{Reporting requirement}

11. Detailed data on domestic financing to government will be provided monthly within six weeks following the end of each month.

\section{B. Reduction of Domestic Payments Arrears}

\section{Definition}

12. Domestic payments arrears comprise: (i) arrears identified at end-1999 on the basis of the audit conducted by the Ministry of Finance in 2005; (ii) the restes à payer at the Treasury exceeding 120 days outstanding at end-2006. The stock of arrears will be reduced to the minimum of the amounts indicated in Table 1 annexed to the MEFP. The quarterly objectives for 2007 are based on the changes in the stock of arrears at end-December 2006 and the date selected for the performance criterion or indicative target. 
13. The Centre d'Amortissement de la Dette Intérieure de l'Etat (CADDIE) and the Treasury are responsible for calculating the stock of domestic arrears, and recording their repayments.

\section{Reporting requirement}

14. Monthly data on the outstanding balance, accumulation (including changes in the restes à payer at the Treasury), and repayment of domestic payments arrears on government obligations will be provided monthly within six weeks following the end of each month.

\section{Reduction of External Payments Arrears}

\section{Definition}

15. Government debt is outstanding debt owed or guaranteed by the government. Under the program, the government undertakes not to accumulate external payments arrears on government debt (including treasury bills and bonds issued in CFA francs on the WAEMU regional financial market), with the exception of external payments arrears arising from government debt being renegotiated with external creditors, including Paris Club creditors.

\section{Reporting requirement}

16. Data on the outstanding balance, accumulation, and repayment of external payments arrears will be provided monthly within six weeks following the end of each month.

\section{External Nonconcessional Loans Contracted or Guaranteed by the Government of Niger}

\section{Definition}

17. The government will not contract or guarantee external debt with original maturity of one year or more with a grant element of less than 50 percent. Nonconcessional external debt is defined as all debt with a concessionality level of less than 50 percent. To calculate the level of concessionality for loans with a maturity of at least 15 years, the discount rate to be used is the ten-year average commercial interest reference rate (CIRR), calculated by the IMF on the basis of the rates published by the OECD; for loans of less than 15 years, the six-month average CIRR is to be used.

18. This performance criterion applies not only to debt as defined in point 9 of the Guidelines on Performance Criteria with Respect to Foreign Dept adopted by the Executive Board on August 24, 2000, but also to commitments contracted or guaranteed for which value has not been received. However, this performance criterion does not apply to financing provided by the Fund, to debt rescheduling in the form of new loans, and to treasury notes and bonds issued in CFA francs on the WAEMU regional financial market. 


\section{Reporting requirement}

19. Details on any external government debt will be provided monthly within six weeks following the end of each month. The same requirement applies to guarantees extended by the central government.

\section{E. Short-Term External Debt of the Central Government}

\section{Definition of the performance criterion}

20. The government will not accumulate or guarantee new external debt with original maturity of less than one year. This performance criterion applies not only to debt as defined in point 9 of the Guidelines on Performance Criteria with Respect to Foreign Debt adopted on August 24, 2000, but also to commitments contracted or guaranteed for which value has not been received. Excluded from this performance criterion are short-term, import-related trade credits and short-term treasury notes issued in CFA francs on the regional financial market.

\section{Reporting requirement}

21. Details on any external government debt will be provided monthly within six weeks following the end of each month. The same requirement applies to guarantees extended by the central government.

\section{F. Pricing of Petroleum Products}

\section{Definition of the performance criterion}

22. The government will continuously implement the monthly pricing mechanism for retail petroleum products in accordance with the decree of August 2001, with the modification that if the formula indicates a price adjustment smaller than CFAF 15, no price change will be introduced. The overall tax per liter will not fall below the level of March 2007 (CFAF 180.1 per liter of gasoline and CFAF 132.2 per liter of diesel). In case of an emergency situation that would require the review of this policy, the government will consult with the Fund concerning the adoption of appropriate measures.

\section{Quantitative TARgets}

\section{A. Definitions}

23. Total revenue is an indicative target for the program. It includes tax, nontax, and special accounts revenue, but excludes revenue from the settlement of reciprocal debts between the government and enterprises. 
24. The basic fiscal deficit is defined as the difference between: (i) total fiscal revenue as defined in paragraph 23; and (ii) total fiscal expenditure excluding foreignfinanced investment (but including HIPC-financed investment).

25. The government undertakes not to accumulate any new domestic payments arrears on government debt as defined in paragraph $2 \mathrm{c}$ above. Thus the amount of the restes à payer at the Treasury with maturities of more than 120 days will not increase in the period from end-December 2006 to end-June, end-September and end-December 2007.

\section{B. Reporting Requirement}

26. This information will be provided to the IMF monthly within six weeks following the end of each month.

\section{AdDitionAl INFORMATION FOR PROGRAM-MONITORING PURPOSES}

\section{A. Public Finances}

27. The government will report to IMF staff the following:

- detailed monthly estimates of revenue and expenditure, including priority expenditure and the payment of domestic and external arrears, and a breakdown of customs, DGI, and Treasury revenue;

- the table of government financial operations with comprehensive monthly data on domestic and external financing, and the changes in arrears (arrears outstanding at end-1999) and restes à payer at the Treasury. These data are to be provided monthly within six weeks following the end of each month;

- quarterly data on the expenditures of the unified priority list, and the data on expenditures on HIPC resources and the President's Special Program, on a payment order basis;

- quarterly data on implementation of the Public Investment Program, including details on financing sources, to be provided quarterly within eight weeks following the end of each quarter;

- monthly data on the balances of the accounts of the Treasury and of other public accounting officers at the BCEAO;

- monthly data on the restes à payer at the Treasury, by reference fiscal year with an itemization of maturities of more than, and less than, 120 days;

- monthly data on effective debt service (principal and interest) compared with the planned schedules. These data are to be provided within four weeks following the end of each month. 


\section{B. Monetary Sector}

28. The government will provide the following information within eight weeks following the end of each month:

- the consolidated balance sheet of monetary institutions and, as appropriate, the balance sheets of selected individual banks;

- the monetary survey within eight weeks following the end of the month (provisional data);

- borrowing and lending interest rates; and

- customary banking supervision indicators for bank and nonbank financial institutions (if necessary, the same indicators for individual institutions may also be provided).

\section{Balance of Payments}

29. The government will provide IMF staff with the following information:

- any revision to balance of payments data (including services, private transfers, official transfers, and capital transactions) whenever they occur; and

- preliminary annual balance of payments data, within six months following the end of the year concerned.

\section{Real Sector}

30. The government will provide IMF staff with the following information:

- disaggregated monthly consumer price indices, monthly within two weeks following the end of each month;

- national accounts, within six months following the end of the year; and

- any revision in the national accounts.

\section{E. Structural Reforms and Other Data}

31. The government will provide the following information:

- any study or official report on Niger's economy, within two weeks following its publication; and

- any decision, order, law, decree, ordinance, or circular with economic or financial implications, upon its publication or, at the latest, when it enters into force. 
Summary of Main Data Requirements

\begin{tabular}{|c|c|c|c|}
\hline Type of Data & Tables & Frequency & $\begin{array}{l}\text { Reporting } \\
\text { Requirement }\end{array}$ \\
\hline \multirow[t]{3}{*}{ Real sector } & National accounts & Annual & $\begin{array}{l}\text { End of year }+ \text { six } \\
\text { months }\end{array}$ \\
\hline & Revisions of national accounts & Irregular & $\begin{array}{l}\text { Eight weeks } \\
\text { following revision }\end{array}$ \\
\hline & Consumer price indexes, disaggregated & Monthly & $\begin{array}{l}\text { End of month }+ \text { two } \\
\text { weeks }\end{array}$ \\
\hline \multirow[t]{8}{*}{$\begin{array}{l}\text { Public } \\
\text { finances }\end{array}$} & $\begin{array}{l}\text { Net government position in the banking } \\
\text { sector }\end{array}$ & Monthly & $\begin{array}{l}\text { End of month }+ \text { six } \\
\text { weeks }\end{array}$ \\
\hline & $\begin{array}{l}\text { Provisional table of government } \\
\text { financial operations, including } \\
\text { breakdown of revenue (DGI, DGD, and } \\
\text { Treasury) and expenditure, including } \\
\text { repayments of domestic wage and non- } \\
\text { wage arrears outstanding at end-1999 } \\
\text { and the change in the restes à payer } \\
\text { (RAP) at the Treasury. }\end{array}$ & Monthly & $\begin{array}{l}\text { End of month }+ \text { six } \\
\text { weeks }\end{array}$ \\
\hline & $\begin{array}{l}\text { Data on the stock of restes à payer at } \\
\text { the Treasury, by reference fiscal year } \\
\text { (total and RAP older than } 120 \text { days) }\end{array}$ & Monthly & $\begin{array}{l}\text { End of month }+ \text { six } \\
\text { weeks }\end{array}$ \\
\hline & $\begin{array}{l}\text { Monthly data on the deposits of the } \\
\text { correspondents with the Treasury }\end{array}$ & Monthly & $\begin{array}{l}\text { End of month }+ \text { six } \\
\text { weeks }\end{array}$ \\
\hline & Investment expenditure execution & Quarterly & $\begin{array}{l}\text { End of quarter }+ \text { eight } \\
\text { weeks }\end{array}$ \\
\hline & $\begin{array}{l}\text { Table of execution of budgetary } \\
\text { expenditures, of the expenditures in the } \\
\text { priority unified list, and of expenditures } \\
\text { on HIPC resources }\end{array}$ & Quarterly & $\begin{array}{l}\text { End of quarter }+ \text { six } \\
\text { weeks }\end{array}$ \\
\hline & General balance of Treasury accounts & Monthly & $\begin{array}{l}\text { End of month }+ \text { six } \\
\text { weeks }\end{array}$ \\
\hline & $\begin{array}{l}\text { Monthly data on Treasury account } \\
\text { balances and other public entities at the } \\
\text { BCEAO. }\end{array}$ & Monthly & $\begin{array}{l}\text { End of month }+ \text { two } \\
\text { weeks }\end{array}$ \\
\hline
\end{tabular}


Petroleum product pricing formula, tax Monthly receipts, and pricing differentials

Monetary and Monetary survey

financial data

Consolidated balance sheet of monetary institutions and, as appropriate, balance sheets of selected individual banks

Lending and deposit interest rates

Banking prudential ratios

Balance of payments

payments

Revised balance of payments data

External debt Outstanding external payments arrears and repayments

Terms of new external loans

Table of effective monthly external debt service (principal and interest) compared with planned schedule
End of month + four weeks

Monthly End of month + six weeks (for provisional data)

End of month + ten weeks (for final data)

Monthly

End of month + eight weeks

Monthly End of month + eight weeks

Quarterly End of quarter + eight weeks

Annual End of year + six months

Irregular Following the revision

Monthly

End of month + six weeks

End of month + six weeks

Monthly End of month + four weeks 


\title{
INTERNATIONAL MONETARY FUND
}

NIGER

\author{
Fifth Review Under the Three-Year Arrangement Under the \\ Poverty Reduction and Growth Facility and Requests for Waiver, \\ Modification of Performance Criteria, and Extension of the Arrangement \\ Informational Annex \\ Prepared by the African Department \\ (In consultation with other departments) \\ Approved by Jean A.P. Clément and Anthony Boote
}

November 8, 2007
- $\quad$ Relations with the Fund. Describes financial and technical assistance by the IMF, and provides information on the exchange rate system. Niger's PRGF arrangement was approved on January 31, 2005.
- $\quad$ Relations with the World Bank. Describes the World Bank Group's strategy and portfolio.




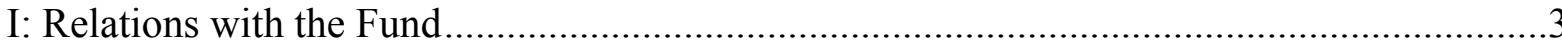

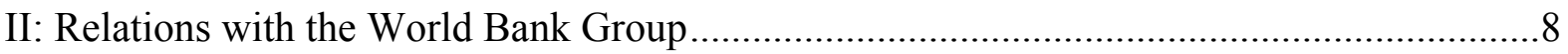

A. Partnership in Niger's development strategy ...............................................................

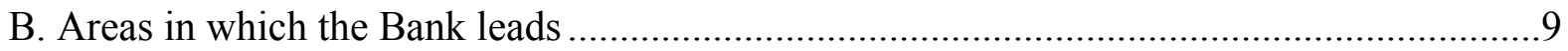

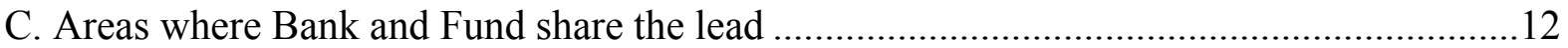

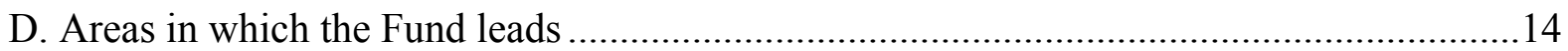

E. World Bank Group Strategy .......................................................................................15 


\section{NigER: RELATIONS WITH THE FUND}

(As of September 30, 2007)

I. Membership Status: Joined: 04/24/1963; Article VIII

II. General Resources Account:

Quota

Fund holdings of currency

Reserve position in Fund

III. SDR Department:

Net cumulative allocation

Holdings

IV. Outstanding Purchases and Loans:

PRGF Arrangements

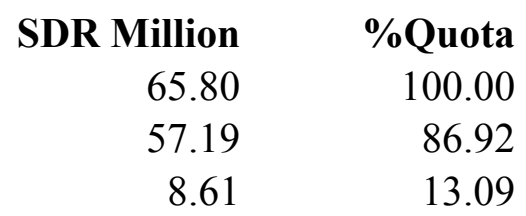

SDR Million

65.80

57.19

8.61

\%Quota 100.00

86.92

13.09

SDR Million

\%Allocation

9.41

100.0

0.05

0.49

SDR Million

\%Quota

24.44

V. Financial Arrangements:

Type

Approval

Date

$01 / 31 / 2005 \quad 01 / 30 / 2008$

PRGF

PRGF

$12 / 22 / 2000$

$06 / 30 / 2004$

PRGF
59.20

Amount Approved (SDR Million)

26.32

57.96
59.20

Amount Drawn

(SDR Million)

$$
24.44
$$

48.30

VI. Projected Payments to Fund (SDR Million; based on existing use of resources and present holdings of SDRs):

Principal

$06 / 12 / 1996 \quad 08 / 27 / 1999$ Forthcoming

\begin{tabular}{lllll}
\hline$\underline{2007}$ & $\underline{2008}$ & $\underline{2009}$ & $\underline{2010}$ & $\underline{2011}$ \\
$\underline{0.15}$ & $\underline{0.48}$ & $\underline{0.48}$ & $\underline{0.48}$ & $\underline{0.47}$ \\
0.15 & 0.48 & 0.48 & 0.57 & 3.41
\end{tabular}

Total 


\section{Implementation of HIPC Initiative:}

I. Commitment of HIPC assistance

Enhanced

Decision point date

Framework

$12 / 20 / 2000$

Assistance committed by all creditors (US\$ million) ${ }^{1 /}$

663.10

of which: IMF assistance (US\$ million)

(SDR equivalent in millions)

Completion point date

April 2004

II. Disbursement of IMF assistance (SDR million)

Amount disbursed

Interim assistance

Completion point balance

24.55

Additional disbursement of interest income ${ }^{2 /}$

Total disbursements

\footnotetext{
${ }^{1 /}$ Assistance committed under the original framework is expressed in net present value (NPV) terms at the completion point, and assistance committed under the enhanced framework is expressed in NPV terms at the decision point. Hence these two amounts cannot be added.

${ }^{2 /}$ Under the enhanced framework, an additional disbursement is made at the completion point corresponding to interest income earned on the amount committed at the decision point but not disbursed during the interim period.
}

\section{Implementation of MDRI assistance:}

Total Debt Relief (SDR million) ${ }^{3 /}$

77.55

of which: MDRI

HIPC

17.73

\footnotetext{
${ }^{3 /}$ The Multilateral Debt Relief Initiative (MDRI) provides 100 percent debt relief to eligible member countries that qualify. The debt relief covers the full stock of debt owed to the Fund as of end-2004, which remains outstanding at the time the member qualifies for such debt relief. The MDRI is financed by bilateral contributions and the Fund's own resources, as well as the resources already disbursed to the member under the HIPC Initiative (see Section VII above).
} 


\section{Safeguards Assessments:}

The Central Bank of West African States (BCEAO) is a common central bank of the countries of the West African Economic and Monetary Union that includes Niger. The most recent safeguards assessment of the BCEAO was completed on November 4, 2005. The assessment indicated progress made in strengthening the bank's safeguards framework since the 2002 assessment and a number of areas where further steps would help solidify it.

The BCEAO now publishes a full set of audited financial statements and improvements have been made to move financial reporting closer to International Financial Reporting Standards (IFRS). Furthermore, an internal audit charter has been put in place, mechanisms for improving risk management have been established and follow-up on internal and external audit recommendations has been strengthened.

The monitoring results of the first half of 2007 indicate certain vulnerabilities, remaining in internal control systems, and some progress achieved in improving the external audit process (including adopting a multi year audit program), establishing an audit committee, expanding disclosures in the notes to financial statements on financial positions with the Fund by countries, including Niger, and further strengthening the effectiveness of the internal audit function.

\section{Exchange Arrangements:}

Niger is a member of the West African Economic and Monetary Union (WAEMU). The exchange system, common to all members of the WAEMU, is free of restrictions on the making of payments and transfers for current international transactions. The WAEMU's common currency, the CFA franc, was originally pegged to the French franc. On January 12,1994 , the CFA franc was devalued by 50 percent in foreign currency terms, and the exchange rate was adjusted from CFAF $50=\mathrm{F} 1$ to CFAF $100=\mathrm{F} 1$. Effective December 31, 1998, the parity was switched to the euro at a rate of CFAF $655.96=$ EUR 1 . On October 23, 2007, the rate of the CFA franc in SDR terms was SDR $1=$ CFAF 717.71. The exchange arrangement of the WAEMU countries is classified as a conventional pegged arrangement.

\section{Article IV Consultation:}

Niger is on the 24-month consultation cycle. The last Article IV consultation discussions were held in Niamey in September-October 2006, and discussed by the Executive Board on December 20, 2006. 
XII. Technical Assistance:

\begin{tabular}{|c|c|c|c|}
\hline Dept. & $\begin{array}{l}\text { Type of } \\
\text { Assistance }\end{array}$ & Time of Delivery & Responsibility \\
\hline FAD & Resident expert & June 2001 to May 2003 & Assistance for tax administration \\
\hline FAD & Staff & May 2002 & $\begin{array}{l}\text { Public accounting and fiscal } \\
\text { operations table }\end{array}$ \\
\hline STA & Staff & January 2003 & Multisector statistical mission \\
\hline FAD & Staff & October 2003 & $\begin{array}{l}\text { Tax policy and revenue } \\
\text { administration }\end{array}$ \\
\hline AFRITAC W & Advisor & April 2004 & Tax administration \\
\hline AFRITAC W & Advisor & August 2004 & Customs administration \\
\hline AFRITAC W & Advisor & October-November 2004 & Tax administration \\
\hline STA & Staff & March 2005 & ROSC \\
\hline AFRITAC W & Advisor and expert & March 2005 & Customs administration \\
\hline AFRITAC W & Advisor & March 2005 & Macroeconomic statistics \\
\hline AFRITAC W & Advisor & March-April 2005 & Microfinance \\
\hline AFRITAC W & Advisor & May-June 2005 & Macroeconomic statistics \\
\hline FAD & Staff & September 2005 & $\begin{array}{l}\text { Tax policy and revenue } \\
\text { administration }\end{array}$ \\
\hline FAD & Expert & $\begin{array}{l}\text { September/October } 2006 \\
\text { and January/February } 2007\end{array}$ & $\begin{array}{l}\text { Tax policy and revenue } \\
\text { administration }\end{array}$ \\
\hline AFRITAC W & Advisor & October 2005 & Customs administration \\
\hline AFRITAC W & Advisor and expert & May 2006 & Macroeconomic statistics \\
\hline AFRITAC W & Advisor & November 2006 & Customs administration \\
\hline AFRITAC W & Advisor and expert & May 2006 & Macroeconomic statistics \\
\hline AFRITAC W & Advisor & December 2006 & Macroeconomic statistics \\
\hline
\end{tabular}




$\begin{array}{llll}\text { AFRITAC W } & \text { Advisor } & \text { January 2007 } & \text { Tax administration } \\ \text { AFRITAC W } & \text { Advisor } & \text { February-March 2007 } & \text { Microfinance } \\ \text { AFRITAC W } & \text { Advisor } & \text { June 2007 } & \text { Macroeconomic statistics } \\ \text { AFRITAC W } & \text { Advisor and expert } & \text { June 2007 } & \text { Customs administration } \\ \text { AFRITAC W } & \text { Advisor and expert } & \text { July 2007 } & \text { Tax administration }\end{array}$

\section{Resident Representative:}

Mr. Pierre Laporte has been resident representative in Niger since December 2005. 


\section{NIGER: RELATIONS WITH THE WORLD BANK GROUP (As of October 31, 2007)}

\section{A. Partnership in Niger's development strategy}

1. Niger's first Poverty Reduction Strategy Paper (PRSP) was adopted in January 2002 and centered on four strategic pillars: (i) a macroeconomic framework ensuring economic and financial stability while promoting sustainable economic growth; (ii) the development of productive sectors, especially in rural areas; (iii) the development of basic social services; and (iv) the promotion of good governance and the strengthening of human and institutional capacities. The PRSP was based on a thorough poverty diagnosis and key development challenges. The Government reconfirmed the main thrust of the PRSP through four progress reports. Bank and Fund staff prepared a Joint Staff Advisory Note (JSAN) which was discussed at the IMF Board in December 2006 and distributed to the Bank's Board on January 11, 2007. The Government has been using the PRSP to improve coordination of development efforts in the country, including donor-supported activities.

2. At a donors' forum in Niamey on June 7 and 8, 2003, donors reaffirmed their endorsement of the PRSP as a strategic anchor for their assistance, and agreed on a progressive shift from project to program financing, and the need for further coordination and harmonization of policies and procedures. The forum resulted in the signing of a protocol agreement by all donors to coordinate their aid to the education sector.

3. Following delays in launching the preparation of analytical background papers, the Government's second PRSP was completed and approved on October 10, 2007 by decree. The PRSP Secretariat visited Washington in early March 2007 for technical discussions on the second PRSP draft and benefited from global knowledge on PRSP and advice for improving the quality of the document from Bank staff together with IMF, UNDP, EU, UNECA and Belgium counterparts. Based on comments received, the government has updated the PRSP and held a national validation workshop in early April to discuss the strategy with parliamentarians, representatives from donor agencies, civil society and local government representatives from various regions of Niger. The second PRSP is built around seven strategic pillars (against four for the previous one) and includes all the main objectives of the first PRSP. The three new pillars are: (i) control of demographic growth; (ii) reduce Inequity and Enhance Social Protection for Vulnerable Groups; and (iii) effective Implementation of the PRSP. A donors Round Table for the financing of the revised PRSP took place in Brussels on October 25-26, 2007 and bilateral and multilateral donors pledged about CFAF 2,000 billions to finance the implementation of the PRS II. 


\section{B. Areas in which the Bank leads}

4. Privatization and regulatory reform. Key utility sectors, such as

telecommunications and water supply have been liberalized and privatized with support from an IDA credit. However, the privatization of the electricity company (NIGELEC) has been delayed mainly due to the difficulty in finding private companies ready to invest US\$60-100 million required for expansion and rehabilitation of the power system. The privatization of the whole sale petroleum product distribution company (SONIDEP) has failed in part because of difficulties in finding sound foreign private partners interested in investing in Niger. With the Bank's assistance, the authorities revisited their objectives and approach to the private provision of infrastructure as they seek to enhance corporate governance for selected state owned companies (NIGELEC, SONIDEP) and create a Government unit to implement the necessary reforms. The Bank supports also the strengthening of the regulatory body $\left(\mathrm{ARM}^{4}\right)$, throughout building its capacity for issuing licenses and managing universal access. The Fund is also a key partner in the policy dialogue in this area, for example through the continuous implementation of a petroleum pricing system.

5. Rural development. The Bank has provided support to Niger to develop and implement a comprehensive rural development strategy (SDR). This strategy aims at mitigating vulnerability and stimulating income generation and is centered on three pillars: (i) improving the access of rural populations to economic opportunities; (ii) protecting rural populations against risks and improving food security and managing natural resources sustainability; and (iii) enhancing the capacity of public institutions and rural organizations to improve the management of the rural sector. An SDR action plan covering the 14 programs of the rural development strategy has been adopted by decree in October 2006. The transition to a budget-program approach for the rural sector was finally completed with the adoption in October 2006, by decree, of a rural sector MTEF, recently updated to cover all line ministries. Bank assistance in this sector is provided through ongoing operations directly linked to the SDR action plan, including: the Private Irrigation Promotion Project II, which aims at increasing production and profitability of high-value, irrigated crops by private, smallholder farmers with simple, low-cost technologies; the Emergency Locust Project aimed at reducing Niger's vulnerability to future desert locust infestations by supporting improved strategies for prevention early warning systems, reactions, and mitigation at both the national and regional levels; and the Community Action Program (CAP), which supports decentralized local financing mechanisms for village groups and communes, as well as promotes an integrated community-based ecosystem management. To enhance its existing investment program, the Bank also supports the GoN in the preparation of an agro-pastoral export promotion project and the second phase of the CAP. Also, in terms of knowledge

\footnotetext{
${ }^{4}$ Autorité de Régulation Multisectorielle.
} 
generating and analytical activities, the Bank provides support to the SDR sustainable land management agenda with activities financed through the TerrAfrica partnership platform, and is also preparing with the GoN an irrigation sector review. The Bank also supports the SDR through the series of Rural and Social Reform Credits (RSRCs), IDA's Development Policy Credits to Niger, approved in June 2006 and 2007. More specifically, the RSRCs help the GoN: (i) improve local governance of natural resources through further decentralization of land administration; (ii) reduce household vulnerability to food insecurity and improve the country's capacity to manage and prevent food crisis; and (iii) increase contribution of irrigation to agriculture GDP.

6. Education sector. Within the framework of the Fast Track Initiative (FTI), Government has prepared a ten-year development plan in the education sector (PDDE) for 2003-2013 in collaboration with the Bank and other donors. The key objectives of the government program, which focuses mainly on primary education, are: (i) increasing access to both formal and non-formal basic education, in particular for children in rural areas, girls, and the poor; (ii) improving the quality and relevance of education; and (iii) developing capacities for the strategic and operational management of the sector at both the central and regional levels and increasing responsibilities assumed at the community level. The preparation of a post-primary education program is also underway and will help to define a strategic framework to ensure sustainable expansion of the secondary and other segments of the system as a response to the growing demands from the primary education leavers. The Bank's Basic Education Project (US\$30 million) supports improved access of the poor to primary education services. In addition, the first and second Rural and Social Reform Credits (RSRC-I and RSRC-II), are helping the government to: (i) implement reforms to increase access of the population to basic education of acceptable quality; (ii) improve personnel management and budget allocations to the education sector; and (iii) foster governance and accountability through information sharing and empowering the community in the education sector. In the context of the FTI, the Bank facilitated the establishment of a Pooled Fund supplied by several donors to finance the PDDE. This Pooled Fund had been frozen following findings of an audit which revealed mismanagement of resources. Government, in earlier 2007, agreed with donors on fiduciary corrective measures to address this issue allowing the resuming of funding by external partners for this sector.

7. Health sector. The Bank has worked with Government on the preparation of the Strategic Orientations for Health Sector Development. In 2002, Government adopted a tenyear health policy strategy (2002-2011). Its main objectives are to further improve access to health services facilities (from 47 percent in 2000 to 80 percent in 2011) and to reduce the incidence of infectious diseases, by promoting new approaches, including preventative behaviors. To make this strategy more operational, Government adopted a five-year development plan for the sector in January 2006 and the Bank approved a US\$35 million IDA credit for the Institutional Strengthening and Health Sector Support project to support a sector wide approach project (SWAP) that also covers reproductive health and malaria services. Through the RSRC's, the Bank is also working with Government to consolidate and 
enhance its reform efforts in the health sector designed to contribute to the following three strategic areas: (i) improve the effectiveness of health services provided through appropriate management of human resources; (ii) improve the efficiency of basic health services provided through appropriate financing of the sector; and (iii) improve the access to basic health services. The Bank has also provided to Niger a $\$ 25$ million IDA Grant for a multisector HIV/AIDS project approved in April 2003.

8. Population. Niger's ability to reduce poverty levels and to meet the MDGs is constrained by its high rate of population growth, estimated at 3.3 percent per annum. Aware of the need to manage demographic dynamics, the Government created in March 2007, a new Ministry of Population and Social Reform. The government also adopted in February 2007 a National Population Policy ${ }^{5}$. At the government's request, a multi-sector demographics operation was prepared and negotiated by the Bank to address the challenge of rapid population growth. The Project was approved by the Board on June 19, 2007 for an amount of US\$10 millions. As part of the project, the Government would launch a communication and sensitization strategy to build national consensus on issues related to improve the status and protection of women and to reduce fertility rates. In addition, the RSRCs will also promote the: (i) launch of information and awareness campaigns on premature marriage and family planning; and (ii) the implementation of action plans to improve the status of women, including organizing a national forum to build consensus.

9. Poverty monitoring. The Bank worked closely with Government to prepare a poverty profile that served as the basis for the PRSP poverty diagnosis. While this diagnosis was considered thorough and comprehensive by the Joint Staff Advisory Note (JSAN), it is outdated as it is based on household survey data from 1993. Updating the existing database is a priority for the Government which recently completed a nationwide census. Preparation of a new household survey, to be partially funded by the government and the Bank, was launched in April 2007 and is expected to be completed in May 2008. A Demographic and Health survey was completed in February 2007. Results showed encouraging improvement of health indicators (infant and child mortality decreased by 34 and 28 percent respectively). The Bank-financed Core Welfare Indicators Survey (CWIQ) was completed in May 2006 with a validation workshop held in Niamey. It provides updated social indicators which are needed for the PRSP update and assessment of progress towards PRSP targets.

10. The Bank, together with other donors, is also advising the authorities on strengthening institutional arrangements for the monitoring and evaluating poverty trends in the context of the PRSP, especially by enhancing the capacity of the National Statistics Institute (INS). In that context, under the RSRC-1, the legal framework required for INS functioning was strengthened last December 2006 with the adoption of personnel status by a

\footnotetext{
${ }^{5}$ Déclaration du Gouvernement en matière de Politique de Population (DGPP).
} 
Bill signed by the Minister of Economy and Finance following the appointment by decree of the INS Board President. With this new legal framework, the INS now has an autonomous personnel payroll scheme in place and the authority to select and hire technical staff without MEF approval. Finally, the INS has prepared the multi-year statistical development plan (2008-2012) to program its activities in the medium-term and secure the requisite financing which was validated by the National Statistical Council in September 2007 and transmitted to the Cabinet for adoption.

11. In addition, the Bank has financed the revision of the 2001 Participatory Poverty Assessment (PPA) as a contribution to Government's efforts to update and strengthen the knowledge base on poverty and social development.

\section{Areas where Bank and Fund share the lead}

12. Poverty reduction strategy. Together with other external development partners, the Bank and Fund have jointly provided assistance to Government in the preparation and updating of its PRSP and the preparation of the Brussels Round Table on PRS financing. Since its completion, both institutions have jointly advised the authorities on the refinement and implementation of the strategy. The four progress reports on the implementation of the PRSP have been prepared with the assistance of the Bank, the Fund and other development partners.

13. Debt sustainability. In April 2005, the Executive Boards of the Bank and Fund endorsed a joint framework for Debt Sustainability Analysis (DSA) in low income countries. A joint Bank/Fund DSA under this framework was completed in December 2006 and updated in October 2007. The DSA indicates that Niger's risk of debt distress is moderate thanks to significant debt reduction achieved in the context of the HIPC Initiative and the Multilateral Debt Relief Initiative (MDRI). Niger is receiving 100 percent debt cancellation from the IMF and IDA under the MDRI, which will free up some US\$30 million per year over the next decade. The results of the DSA show however that Niger's debt situation: i) would worsen significantly in the event of shocks or weaker economic performance; and ii) is particularly sensitive to the terms and composition of external financing. Hence, the authorities need to pursue sound macroeconomic policies and reforms, with particular focus on growth-enhancing measures, and prudent debt policies. The urgent need to build technical and institutional capacity for debt management has been stressed by the Bank and the Fund. Several measures aiming to strengthen the external debt unit were implemented as structural benchmarks under the previous PRGF. Bank and Fund staffs have also supported the external evaluation of the use of HIPC resources under the President Special Program. As agreed in the Bank's Public Expenditure Reform operation (PERCG), the government integrated HIPC resources into the human development sectoral expenditures included in the 2006 Budget Law and is in the process of expanding this to rural development expenditures following completion of the rural sector MTEF in June 2006 and the elaboration of sector Program Budget. 
14. Budgetary and public expenditure reforms. Strengthening public finances is a prerequisite for success of Niger's broader reform agenda. The Bank and Fund share the lead in this area. Both institutions have played key roles in helping Government reduce domestic and external arrears. While the Fund is leading the dialogue on revenue-enhancing measures, the Bank is concentrating its efforts on budgetary reforms, in particular in the area of public expenditure, accounting and cash management system. The Fund with the support of West AFRITAC is also providing key contributions to improve budgetary processes: a number of important measures, such as preparation of budget review laws and computerization of budgetary expenditure, have been included as structural benchmarks in the previous PRGF arrangement. In 2004, the Bank prepared jointly with Government, EU, AfDB and France a comprehensive assessment of Niger's Public Expenditure Management Systems and Capacities (Public Expenditure Management and Financial Accountability Review: PEMFAR). The Bank has supported budgetary reforms through five adjustment operations (PEAC I, PEAC II, PERCG, RSRC I and RSRC II). Consolidating and deepening these reforms (based on the PEMFAR priority action plan) was a critical objective of the RSRC I. The Country Procurement Assessment Report (CPAR) was updated in 2004.

15. Financial sector reform. Government launched a comprehensive financial sector reform program in 2002. Supported by the Financial Sector Technical Assistance Loan approved in February 2004, the program covers the regulatory and legal environment, the banking sector, micro-finance, postal financial services and social security. Some progress has already been realized. Two commercial banks, BCN and BINCI and three insurance companies were restructured and recapitalized. Audits of all major micro-finance institutions have been completed and restructuring plans for the post office have been drawn. In the next two to three years, measures will be taken to improve the legal and judicial environment (modification of legislation for the issuing of land titles, improvement of the legal framework for the taking of guarantees, training of magistrates, etc.). The Housing Bank (CDN) should have been either privatized or liquidated by end December 2006 but the government requested to extend the deadline for the privatization process to be completed. Some progress has been made in the process. Based on its adviser's assessment and proposed options for privatization, the Government published in December 2006, an international tender to privatize $\mathrm{CDN}$ to a strategic investor. Five (5) bidders were qualified. The local Community Lending Bank (CPCT) should be restructured. Micro-finance institutions will be restructured on the basis of the results of the audits, and the supervisory unit at the Ministry of Finance and Economy will be strengthened with the creation of a Microfinance Institutions Regulation Authority by decree on April 6, 2007. The post office was split into two entities in 2005, Niger Post, for pure mail transactions, and FinaPoste, a financial services affiliate. Finally, an actuarial audit was conducted of the CNSS, the social security institution.

16. Civil service reform and decentralization. The reform and modernization of the civil service is an important element of Niger's PRSP, yet there has been little progress in this area so far. The authorities are currently making an effort to put in place an integrated civil service database. By allowing a more transparent and effective management of the civil 
service, this database should improve control over the wage bill. Controlling the wage bill is important for maintaining fiscal balance, as recognized by the previous PRGF arrangement, which had set quantitative benchmarks for the wage bill. The planning for the implementation of the legal framework for the political decentralization of 1996 has recently gained momentum. Following the first local elections of July 2004, the Government needs support with reforms to strengthen capacity at the local level and deal with the fiscal implications of decentralization. To help Government address some of these concerns, the Community Action Program and the forthcoming Local Urban Infrastructure Development Project (planned for FY08) will help build capacities in rural communities in planning, implementing, and monitoring micro-development projects.

17. Extractive Industry Transparency Initiative (EITI): Niger expressed its adhesion to EITI at the March 2005 London Conference after the endorsement of the initiative at the Council of Ministers. Niger has since been working on a draft institutional setup for EITI implementation which is expected to include: i) a management council composed of the main ministers involved in the administration of extractive industries in Niger and headed by the Prime Minister, ii) the consultative council including representatives of the partners for implementation i.e. the public institutions, the civil society and the companies, and iii) a permanent secretariat headed by the EITI implementation supervisor. A national workshop took place on September 6-7, 2006 to launch the initiative in Niger and was chaired by the Prime Minister. Niger is a full member of EITI since August 2007, with the appointment of the EITI Permanent Secretary and the validation of the action plan.

\section{Areas in which the Fund leads}

18. Macroeconomic management. The main objectives of Niger's macroeconomic program, as stated in the PRSP, are to ensure economic and financial stability while promoting sustainable and robust growth. The Fund is supporting this program through its PRGF framework by providing financial and technical assistance, as well as through dialogue on macroeconomic policy reforms. The program has made satisfactory progress since approval of the first PRGF arrangement in 2000 by achieving most of its benchmarks and overall positive fiscal performance. A second PRGF was approved in January 2005 and four reviews were successfully completed to date. In the context of the macroeconomic framework underlying the PRSP, the Bank has provided technical assistance in building capacity in the Ministry of Finance and Economy to monitor economic performance; elaborate MTEF and Program Budget in key sectoral ministries (Education, Health and Rural Development); and macroeconomic modeling.

19. Fiscal policy. Fiscal consolidation is a key objective of the PRGF and is supported by a number of performance criteria and benchmarks. Increasing budgetary revenue in order to progressively lower the Government's reliance on external assistance is particularly important, given Niger's low level of revenues, compared with regional partners in WAEMU. In terms of expenditures, the Fund is mainly concerned with overall budget 
envelopes, while the Bank focuses on inter and intrasectoral allocations and protection of key expenditure items in Education, Health and Rural Development.

20. Monetary policy. The Fund leads the policy dialogue on monetary policy, which is set by the regional monetary authorities (BCEAO).

\section{E. World Bank Group Strategy}

21. The Bank's most recent Country Assistance Strategy (CAS) covered the period 2003 to 2005 and was approved by the Bank's Board in January 2003. It supports the implementation of the PRSP. A new CAS is under preparation and Board presentation is planned in FY08.

22. As of October 31, 2007, the World Bank lending portfolio in Niger consisted of eleven IDA active operations, with a total commitment of US\$311.4 million, of which US\$132.8 million is undisbursed. IDA assistance has helped reduce the volatility in ODA by compensating short-term declines in assistance from other partners, in particular throughout two Rural and Social Reforms Credit and Grant. IDA has also been responsive to regional exogenous shocks that have implications for Niger. For instance, an Africa Emergency Locust Project (AELP) aiming at fighting the locust's infestation in West Africa was delivered in FY05 and a Niger Avian Influenza Control and Human Pandemic Preparedness and Response Activities program is under preparation. A Health sector SWAP and RSRC 1 were delivered in FY 06. IDA assistance to Niger in FY07 was 100\% on non-repayable grant terms. Additional IDA Financing of \$10 million (Grant) was provided for the Water Sector project in July 2006. In FY07, the Bank have delivered two additional projects, RSRC 2 (\$50 million IDA Grant of which 25 millions were disbursed in August 2007) and the Multisector Demographic Project (\$10 million IDA Grant), both approved by the Board on June 19, 2007. Within a medium-term framework, and building on the previous three budget support operations as well as ongoing investment projects in agriculture, education, and health, the RSRC series focus on helping Government overcome policy constraints and institutional bottlenecks in: (i) public sector management; (ii) growth and agricultural development; and (iii) human development, including demographic growth and gender issues. Going forward, the RSRC series will shift to support the accelerated and shared growth agenda, in particular to support policy reforms in the area of infrastructure and private sector development. 
Table 1: Niger Status of World Bank Portfolio (all IDA)

(In millions of U.S. dollars, as of October 31, 2007)

\begin{tabular}{|l|c|c|c|c|}
\hline & $\begin{array}{c}\text { Commit } \\
\text { Amount } \\
\text { (US\$ mil) }\end{array}$ & $\begin{array}{c}\text { Undis- } \\
\text { bursed }\end{array}$ & $\begin{array}{c}\text { Approval } \\
\text { Date }\end{array}$ & $\begin{array}{c}\text { Closing } \\
\text { Date }\end{array}$ \\
\hline $\begin{array}{l}\text { Rural and Social Sectors Reforms Grant II } \\
\text { (RSRC II) }\end{array}$ & 50.0 & 25 & $19-06-07$ & $30-06-2008$ \\
\hline Multi-Sector Demographic Project & 10.0 & 10.0 & $19-06-07$ & $31-03-2013$ \\
\hline $\begin{array}{l}\text { Niger Basin Water Resources Development and } \\
\text { Sustainable Ecosystem Management project }\end{array}$ & 15.0 & 15.0 & $03-07-07$ & $31-01-2013$ \\
\hline $\begin{array}{l}\text { Instit. Strengthening \& health Sector Support } \\
\text { Program (ISHSS) }\end{array}$ & 35 & 30.5 & $05-01-06$ & $30-01-2011$ \\
\hline Locust Emergency & 9.9 & 5.6 & $16-12-04$ & $30-06-09$ \\
\hline Water Sector & 48.0 & 9.8 & $03-05-01$ & $31-12-08$ \\
\hline Private Irrigation Promotion & 38.7 & 4.3 & $19-03-02$ & $31-12-07$ \\
\hline Community Action Program & 35.0 & 1.0 & $20-03-03$ & $30-06-07$ \\
\hline Basic Education & 30.0 & 11.1 & $17-07-03$ & $31-12-07$ \\
\hline Multi-sector STI/HIV-AIDS & 25.0 & 11.5 & $04-04-03$ & $30-06-08$ \\
\hline Financial Sector TA & 14.8 & 9.0 & $19-02-04$ & $30-04-08$ \\
\hline & $\mathbf{3 1 1 . 4}$ & $\mathbf{1 3 2 . 8}$ & & \\
\hline
\end{tabular}

23. The Bank's AAA program helps the Government in areas such as poverty analysis, gender, population growth, sources of growth, and the Millennium Development Goals (MDGs). The AAA program also aims at reinforcing public sector capacity in pursuit of the PRSP's objectives and in preparing Niger to transition to consolidated programmatic lending. In support of these objectives, sector work on population, rural development, public expenditure management and financial accountability review (PEMFAR), CPAR, and Participatory Poverty Assessment have been completed. A Country Economic Memorandum (CEM) focusing on accelerating growth and achieving the MDGs in Niger was prepared in FY06 and finalized with comments from the Government of Niger and is expected to be disseminated in October 2007. The draft chapters of the Diagnostic Trade Integration Study was discussed together with the final report of the Investment Climate Assessment at a national workshop held in Niamey on June 26-27, 2007. The ICA report portrayed a negative environment for private sector in Niger; however the government is taking corrective measures to improve business environment with TA from donors. To help the Government reduce vulnerability to food insecurity and develop a comprehensive social protection strategy, the Bank is preparing a sector work on food security and social protection for Niger. Finally, the Bank is preparing a Public Expenditure Tracking Survey (P.E.T.S.), initially in the education and health sectors. The objectives of the P.E.T.S. is to improve the efficiency 
of public spending in social sectors and enhance the social sector outcomes by tracking leakages, execution rate, and delays of public spending as well as document administrative procedures.

24. The Bank is committed to enhancing external partnerships and donor harmonization within the framework of the Government's efforts to mobilize and coordinate donor support under the PRSP. In addition to the strong partnership with the Fund, the Bank is collaborating with a number of donors in different areas, including the European Union (EU), the African Development Bank (AfDB), the United Nations Development Program (UNDP), and key bilateral donors. 


\section{INTERNATIONAL DEVELOPMENT ASSOCIATION AND \\ INTERNATIONAL MONETARY FUND}

\section{NIGER}

\section{Joint Fund-Bank Debt Sustainability Analysis}

Prepared by the staffs of the International Development Association and the International Monetary Fund

Approved by Brian Pinto and Sudhir Shetty (World Bank)

and Jean A.P. Clément and Anthony Boote (IMF)

November 9, 2007

Niger remains at moderate risk of debt distress. Despite low debt ratios following debt relief, most recently in 2006 under the MDRI, Niger has high external financing needs and a narrow export base. Although the public debt remains at acceptable levels under most stress tests, external debt breaches one policy-dependent debt distress threshold under scenarios incorporating export shocks, lower growth, and less generous financing terms.

\section{BACKGROUND}

25. This joint IMF-World Bank debt sustainability analysis evaluates both the external and the total public debt profile of Niger based on end-2006 data, using the standard debt dynamics templates for low income countries. ${ }^{6}$

\section{Niger's debt ratios have been significantly reduced by debt relief, most recently} under the MDRI. Niger reached completion point of the HIPC Initiative in April 2004 and subsequently benefited from MDRI assistance from the IMF, IDA, and the African Development Bank in 2006. Nominal external debt has thus fallen from over 90 percent of GDP at end-2000 to less than 15 percent of GDP at end-2006. By end-2006, debt to AfDB, IDA and the IMF accounted for 8 percent, 23 percent and 5 percent of external debt, respectively, while the remainder was constituted by borrowing from other multilateral lenders.

\section{UNDERLYING DSA ASSUMPTIONS}

27. The result of the current exercise differs from the 2006 DSA mainly because of: (i) an expected acceleration of exports and GDP resulting from a substantial increase in uranium

\footnotetext{
${ }^{6}$ The DSA was produced jointly by staffs of the IMF and the World Bank.
} 
prices and the ongoing expansion of uranium production capacity; and (ii) a modestly lower grant element for concessional loans that reflects more accurately the terms for project financing available to Niger from multilateral agencies. ${ }^{7}$ Box 1 describes the main macroeconomic assumptions used for the baseline debt burden ratio calculations. The faster exports growth projected (12 percent per year in 2007-16) represents a break from the past (5.5 percent per year in 1997-2006) when mining exports were stagnant, reflecting low uranium prices. ${ }^{8}$

\section{EXTERNAL DSA}

28. Under the baseline scenario, all external debt ratios remain below their policydependent indicative thresholds throughout the projection period (2007-27) (Text Table). The present value (NPV) of debt-to-GDP ratio rises gradually and stabilizes below 25 percent by 2027, while the NPV of debt-to-exports ratio levels off at about 116 percent (Table $1 \mathrm{~b}$ and Figure 1). The gradual rise in these indicators results from Niger's high financing requirements, critical for promoting growth and achieving the MDGs: it is assumed that one third of total project financing comes in the form of concessional loans and the remainder in grants.

\section{Policy-Based External Debt Burden Indicators}

Thresholds $1 /$

Niger: Baseline Scenario Ratios

NPV of external debt in percent of:

\section{Exports}

GDP

Revenue

External debt service in percent of:

Exports

Revenue
150

40

250

20

30
62.6

10.2

77.6

2.8

3.5
87.0

17.4

114.7

3.8

5.0
115.5

22.8

132.3

1/ Policy-dependent thresholds as used in the joint IMF-WB LIC DSA framework for a medium policy performance. Niger received a rating of 3.3 in the 2006 World Bank's Country Policy and Institutional Assessment (CPIA), which qualifies it as a medium-policy performer.

2/ Simple Average.

\footnotetext{
${ }^{7}$ The analysis assumes an average grant element of 46 percent in borrowing after 2008, compared to 50 percent in the 2006 DSA.

${ }^{8}$ The uranium price assumptions are conservative looking forward as they are based on only modest annual increases from the 2007 contract price, which is still low in comparison to the international spot price.
} 


\section{Sensitivity tests show that Niger's external debt burden could worsen} significantly in the event of plausible adverse macroeconomic shocks-particularly to exports_or weaker economic performance, although ratios would remain below their threshold levels under most of these alternative scenarios. If key variables remain at the historical average of the previous ten years (scenario A1), the NPV of debt-to-GDP and debtto-exports ratios would rise to 18 percent and 90 percent respectively by 2027 , below the baseline. This lower debt profile under the historical scenario reflects a lower level of borrowing and smaller current account deficits than are assumed going forward. In contrast, two alternative scenarios - a temporary but strong reduction in export growth (scenario B2), or a sizeable deterioration of the terms for new borrowing (scenario A2) ${ }^{9}$ — would result in a more significant worsening of Niger's debt profile, leading to breaches of the debt-to-exports threshold (but not of any other threshold). Under the first of these tests, the export shock, the NPV of debt-to-exports ratio would peak in the medium term at 149 percent (just below its 150 percent threshold) but subsequently returns to a rising long-run trajectory, reaching 179 percent by 2027. Under the second of these, assuming costlier financing terms, debt-toexports would rise more gradually, nonetheless reaching 180 percent by 2027 . Similarly, under a 35 percent grant element for new borrowing (scenario A4), the NPV of debt-toexports ratio gradually rises to 164 percent by 2027 .

\section{Niger's external vulnerability is underlined by a further country-specific} scenario capturing poor investment outcomes, under which the high inflows and investment under the baseline scenario do not lead to any growth dividend (scenario A3). Real GDP growth was set to its historical (ten year) average (3.4 percent) while current account deficits and borrowing patterns were left as in the baseline. This scenario can be thought of as roughly simulating poor performance in the public investment program in the coming years, and also in the uranium sector. Under this scenario, the NPV of debt-to-GDP ratio gradually rises to 31 percent by the end of the forecast period, thus respecting the 40 percent threshold.

\section{Public DSA}

\section{Consideration of total public debt, including domestic debt, does not}

significantly alter the assessment. Domestic debt stood at approximately 11 percent of GDP (45 percent of total public debt) at end-2006 but is projected to fall under the baseline scenario, reaching about 5 percent by 2013 and continuing to decline thereafter (Table 2a). This pattern is explained by relatively low primary fiscal deficits, averaging 2.5 percent of GDP for the first six years of the projection period and less than 2 percent thereafter. The average interest rate on domestic debt is very low (1.4 percent) as the bulk of the debt is constituted by non-interest bearing arrears.

\footnotetext{
${ }^{9}$ Under scenario A2, interest costs are 2 percentage points above the baseline.
} 


\section{A significant proportion of domestic debt as of end-2006 is accounted for by}

domestic arrears. The baseline analysis therefore also takes into account the ongoing implementation of a domestic arrears reduction plan, which reduces domestic debt to 10 percent of total public debt by 2013, and nearly eliminates it by 2017. Under these assumptions, total public sector debt (NPV) would remain stable at around 20 percent of GDP up to 2017 and then gradually increase, but driven solely by new external debt. Two sensitivity tests generate a significant rise of public debt. The first of these is the standardized stress test incorporating a two-year low growth shock. The second is the country-specific lower long-run growth scenario described above. In both cases, total public debt (NPV) reaches about 40 percent of GDP, and about 175 percent of forecast revenue, by the end of the projection period (Figure 2).

\section{Conclusion}

33. Staff assessment is that despite low current levels of debt, Niger remains at moderate risk of debt distress over the medium to long term. This risk assessment is the same as in the previous 2006 DSA. Debt and debt service ratios remain at comfortable levels under the baseline assumptions and stress tests reveal breaches of the policy-dependent external debt-to-exports threshold only under three of the eight standardized stress tests. Niger is financing significant current-account deficits and the baseline used for this DSA incorporates GDP growth rates that are based on the assumed impact of a large program of public investment and rapid expansion in mining. The standardized tests of export shocks or costlier financing terms underline the moderate risk assessment.

34. The results of the DSA underscore the need for the authorities to pursue prudent debt policies, seeking maximum concessionality, combined with sound macroeconomic management and export diversification. While the debt profile has improved with the granting of HIPC and MDRI assistance and better prospects for sustained growth, the country remains vulnerable to external shocks. Policies should therefore aim to boost growth and diversify the productive base, particularly exports, while continuing to privilege grants and highly concessional loans. 


\section{Box 1. Baseline scenario assumptions}

The baseline macroeconomic scenario for 2007-27 hinges on the following assumptions:

- Real GDP growth is expected to rise from its historical average (1997-2006) of 3.4 percent to an average of 5.5 percent in 2007-16, fostered mainly by increased investment and production of uranium. In 2017-27, after a moderation of the uranium boom, annual GDP growth is expected to settle at about 5 percent. This level is still above the historical average, and results from planned investments in irrigation and infrastructure, as well as of ongoing reforms to improve the investment climate.

- The investment rate is projected to be high in 2007-12, between 25 and 28 percent of GDP, partly as a result of planned uranium-related investments. Investment would remain at around 20 percent of GDP in 2014-27, as mining-related investment decline.

- The assumed GDP deflator would be below 2.5 percent throughout the period.

- The revenue-to-GDP ratio is projected to rise gradually from 12.9 percent in 2006 to about 17 percent by 2025, reflecting the gradual convergence of the tax revenue ratio to the WAEMU norm (17 percent). Public expenditures would rise sharply from 18.6 percent of GDP in 2006 to 23 percent by 2008 , and should remain between 23 and 24 percent of GDP during the rest of the projection period, reflecting the authorities' efforts to promote growth and increase social spending.

- The evolution of total exports in the medium term will be largely determined by developments in uranium exports, resulting from investments to expand production and from higher prices.

Investments related to uranium in 2008-2012 are projected at around 30 percent of GDP, leading to a tripling of current production by 2014 mainly because of the new Imourarem project. Uranium prices have increased by 60 percent from 2006 to 2007, and are conservatively projected to increase by 2 percent per year in the future. With the sharp increase in uranium exports, overall exports growth in current price, is projected at about 12 percent per year in 2007-16, which compares to 5.5 percent in the last ten years when mining exports were stationary.

- With a moderation in the growth of uranium exports and drop in gold production (expected to peak in 2010), growth in exports after 2016 is largely dependent on expected acceleration in other sectors. Nominal exports are projected to grow during 2017-2027 at about 7 percent per year.

- Uranium-related activity will also boost other items of the current account through increased imports of equipment and capital goods, higher repatriation of profits, and larger compensation to foreign employees. Hence, total imports in nominal terms would grow around 9 percent on average during 2007-16, with the current account deficit-to-GDP ratio reaching a peak in 2012. Afterwards, imports are projected to grow broadly in line with nominal GDP growth, with the current account deficit as a share to GDP declining gradually.

- The average interest rate on new external borrowing is projected at 1.2 percent, assuming half of new external debt is contracted on IDA terms and half at an interest rate of about 2 percent. Project financing in the form of external grants and loans is projected to rise in line with nominal GDP, with grants being two thirds of the total. External budgetary financing will remain stable in current terms after reaching a peak in 2007-08, with grants also about two thirds of the total.

- The domestic debt profile assumes a reduction of domestic arrears in 2007-13 and no domestic financing of the deficit after 2017. The average interest rate on the stock of debt is very low (1.4 percent) because arrears do not pay interest. The interest rate of new domestic financing up to 2017 is assumed at 4 percent.

- These assumptions lead to an improvement in the non-interest current account deficit from an average of 12 percent of GDP in 2006-10 to about 8 percent of GDP by 2025 . 
Box 1 (continued). Baseline scenario assumptions
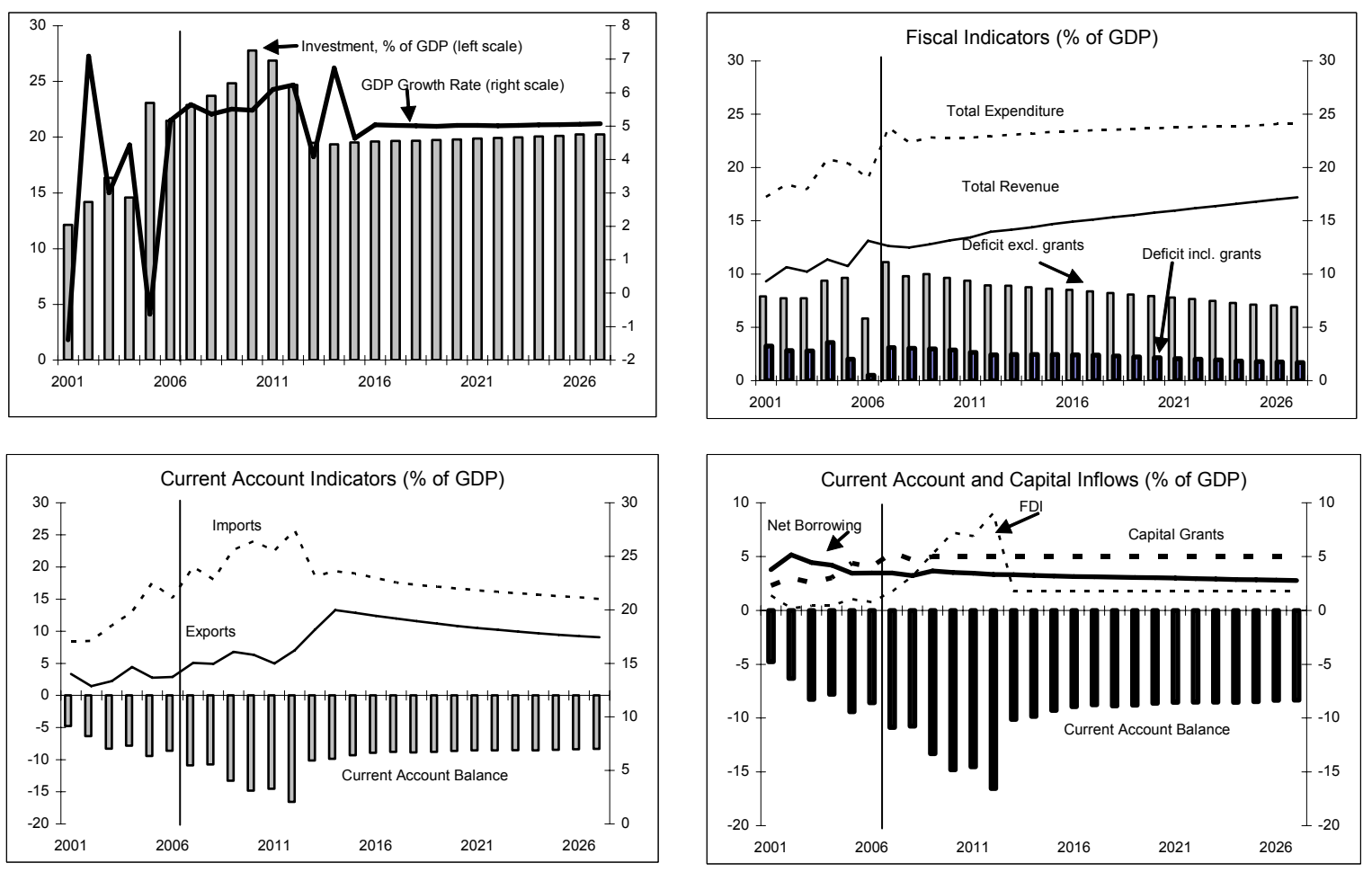


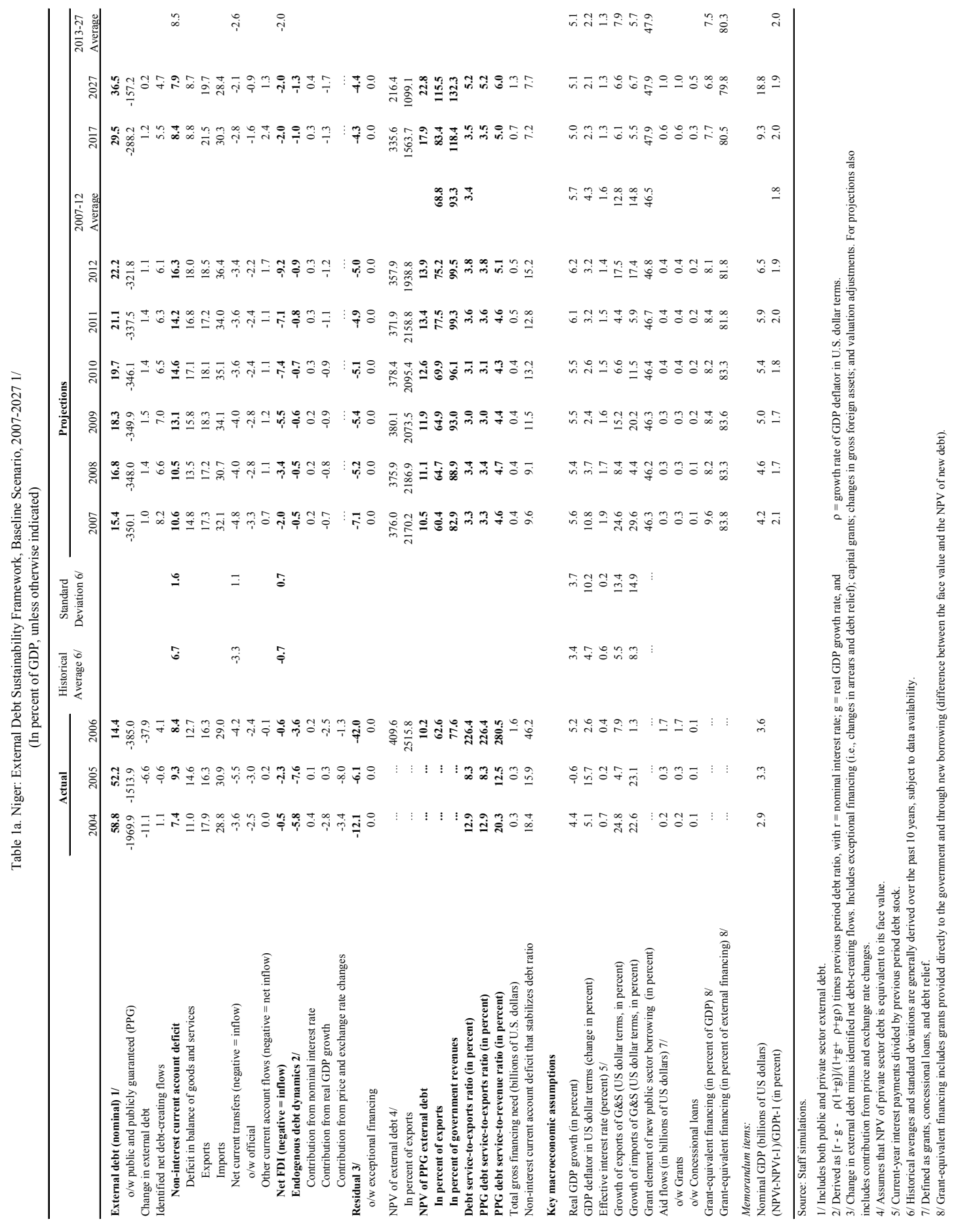


Table 1b. Niger: Sensitivity Analyses for Key Indicators of Public and Publicly Guaranteed External Debt, 2007-27 (In percent)

\begin{tabular}{|c|c|c|c|c|c|c|c|c|}
\hline \multirow[b]{4}{*}{ Baseline } & \multicolumn{8}{|c|}{ Projections } \\
\hline & 2007 & 2008 & 2009 & 2010 & 2011 & 2012 & 2017 & 2027 \\
\hline & \multicolumn{8}{|c|}{ NPV of debt-to-GDP ratio } \\
\hline & 10 & 11 & 12 & 13 & 13 & 14 & 18 & 23 \\
\hline \multicolumn{9}{|l|}{ A. Alternative Scenarios } \\
\hline A1. Key variables at their historical averages in $2008-271 /$ & 10 & 11 & 10 & 11 & 11 & 11 & 12 & 18 \\
\hline A2. New public sector loans on less favorable terms in $2008-272 /$ & 10 & 12 & 13 & 15 & 16 & 17 & 25 & 35 \\
\hline A3. GDP growth at historical average in $2008-27$ & 10 & 11 & 12 & 13 & 15 & 16 & 22 & 32 \\
\hline A4. New public sector loans with $35 \%$ grant element in $2008-27$ & 10 & 12 & 13 & 14 & 15 & 16 & 23 & 32 \\
\hline \multicolumn{9}{|l|}{ B. Bound Tests } \\
\hline B1. Real GDP growth at historical average minus one standard deviation in 2008-09 & 10 & 12 & 13 & 14 & 15 & 16 & 20 & 25 \\
\hline B2. Export value growth at historical average minus one standard deviation in 2008-09 3/ & 10 & 12 & 16 & 17 & 17 & 18 & 21 & 24 \\
\hline B3. US dollar GDP deflator at historical average minus one standard deviation in 2008-09 & 10 & 12 & 14 & 15 & 16 & 17 & 21 & 27 \\
\hline B4. Net non-debt creating flows at historical average minus one standard deviation in 2008-09 4/ & 10 & 14 & 18 & 19 & 19 & 20 & 23 & 25 \\
\hline B5. Combination of B1-B4 using one-half standard deviation shocks & 10 & 14 & 19 & 20 & 20 & 20 & 24 & 28 \\
\hline \multirow[t]{2}{*}{ B6. One-time 30 percent nominal depreciation relative to the baseline in 2008 5/ } & 10 & 16 & 17 & 18 & 19 & 20 & 25 & 32 \\
\hline & \multicolumn{8}{|c|}{ NPV of debt-to-exports ratio } \\
\hline Baseline & 60 & 65 & 65 & 70 & 77 & 75 & 83 & 116 \\
\hline \multicolumn{9}{|l|}{ A. Alternative Scenarios } \\
\hline A1. Key variables at their historical averages in $2007-261 /$ & 60 & 62 & 57 & 59 & 63 & 60 & 57 & 90 \\
\hline A2. New public sector loans on less favorable terms in $2007-262 /$ & 60 & 69 & 73 & 82 & 94 & 95 & 118 & 180 \\
\hline A3. GDP growth at historical average in $2008-27$ & 60 & 65 & 65 & 70 & 77 & 75 & 83 & 116 \\
\hline A4. New public sector loans with $35 \%$ grant element in $2008-27$ & 60 & 67 & 70 & 78 & 89 & 88 & 108 & 164 \\
\hline \multicolumn{9}{|l|}{ B. Bound Tests } \\
\hline B1. Real GDP growth at historical average minus one standard deviation in 2008-09 & 60 & 65 & 65 & 70 & 77 & 75 & 83 & 116 \\
\hline B2. Export value growth at historical average minus one standard deviation in 2008-09 3/ & 60 & 85 & 131 & 138 & 149 & 141 & 145 & 179 \\
\hline B3. US dollar GDP deflator at historical average minus one standard deviation in 2008-09 & 60 & 65 & 65 & 70 & 77 & 75 & 83 & 116 \\
\hline B4. Net non-debt creating flows at historical average minus one standard deviation in 2008-09 4/ & 60 & 81 & 100 & 105 & 112 & 106 & 105 & 125 \\
\hline B5. Combination of B1-B4 using one-half standard deviation shocks & 60 & 81 & 114 & 120 & 129 & 123 & 126 & 156 \\
\hline \multirow[t]{2}{*}{ B6. One-time 30 percent nominal depreciation relative to the baseline in 20085 / } & 60 & 65 & 65 & 70 & 77 & 75 & $\mathbf{8 3}$ & 116 \\
\hline & \multicolumn{8}{|c|}{ Debt service-to-exports ratio } \\
\hline Baseline & 3.3 & 3.4 & 3.0 & 3.1 & 3.6 & 3.8 & 3.5 & 5.2 \\
\hline \multicolumn{9}{|l|}{ A. Alternative Scenarios } \\
\hline A1. Key variables at their historical averages in $2008-271 /$ & 3.3 & 3.4 & 3.0 & 2.9 & 3.4 & 3.6 & 2.9 & 3.6 \\
\hline A2. New public sector loans on less favorable terms in 2008-27 2/ & 3.3 & 3.4 & 3.2 & 3.5 & 4.4 & 4.6 & 5.1 & 9.3 \\
\hline A3. GDP growth at historical average in $2008-27$ & 3.3 & 3.4 & 3.0 & 3.1 & 3.6 & 3.8 & 3.5 & 5.2 \\
\hline A4. New public sector loans with $35 \%$ grant element in $2008-27$ & 3.3 & 3.4 & 3.1 & 3.3 & 4.0 & 4.2 & 4.3 & 7.9 \\
\hline \multicolumn{9}{|l|}{ B. Bound Tests } \\
\hline B1. Real GDP growth at historical average minus one standard deviation in 2008-09 & 3.3 & 3.4 & 3.0 & 3.1 & 3.6 & 3.8 & 3.5 & 5.2 \\
\hline B2. Export value growth at historical average minus one standard deviation in 2008-09 3/ & 3.3 & 4.0 & 4.7 & 5.3 & 6.1 & 6.3 & 6.0 & 8.6 \\
\hline B3. US dollar GDP deflator at historical average minus one standard deviation in 2008-09 & 3.3 & 3.4 & 3.0 & 3.1 & 3.6 & 3.8 & 3.5 & 5.2 \\
\hline B4. Net non-debt creating flows at historical average minus one standard deviation in 2008-09 4/ & 3.3 & 3.4 & 3.4 & 3.9 & 4.4 & 4.5 & 4.4 & 6.1 \\
\hline B5. Combination of B1-B4 using one-half standard deviation shocks & 3.3 & 3.7 & 4.1 & 4.6 & 5.3 & 5.5 & 5.2 & 7.5 \\
\hline B6. One-time 30 percent nominal depreciation relative to the baseline in 20085 / & 3.3 & 3.4 & 3.0 & 3.1 & 3.6 & 3.8 & 3.5 & 5.2 \\
\hline \multicolumn{9}{|l|}{ Memorandum item: } \\
\hline Grant element assumed on residual financing (i.e., financing required above baseline) 6/ & 46.6 & 46.6 & 46.6 & 46.6 & 46.6 & 46.6 & 46.6 & 46.6 \\
\hline
\end{tabular}

Source: Staff projections and simulations.

1/ Variables include real GDP growth, growth of GDP deflator (in U.S. dollar terms), non-interest current account in percent of GDP, and non-debt creating flows.

2/ Assumes that the interest rate on new borrowing is by 2 percentage points higher than in the baseline., while grace and maturity periods are the same as in the baseline.

3/ Exports values are assumed to remain permanently at the lower level, but the current account as a share of GDP is assumed to return to its baseline level after the shock (implicitly assuming an offsetting adjustment in import levels).

4/ Includes official and private transfers and FDI.

5/ Depreciation is defined as percentage decline in dollar/local currency rate, such that it never exceeds 100 percent.

6/ Applies to all stress scenarios except for A2 (less favorable financing) in which the terms on all new financing are as specified in footnote 2. 


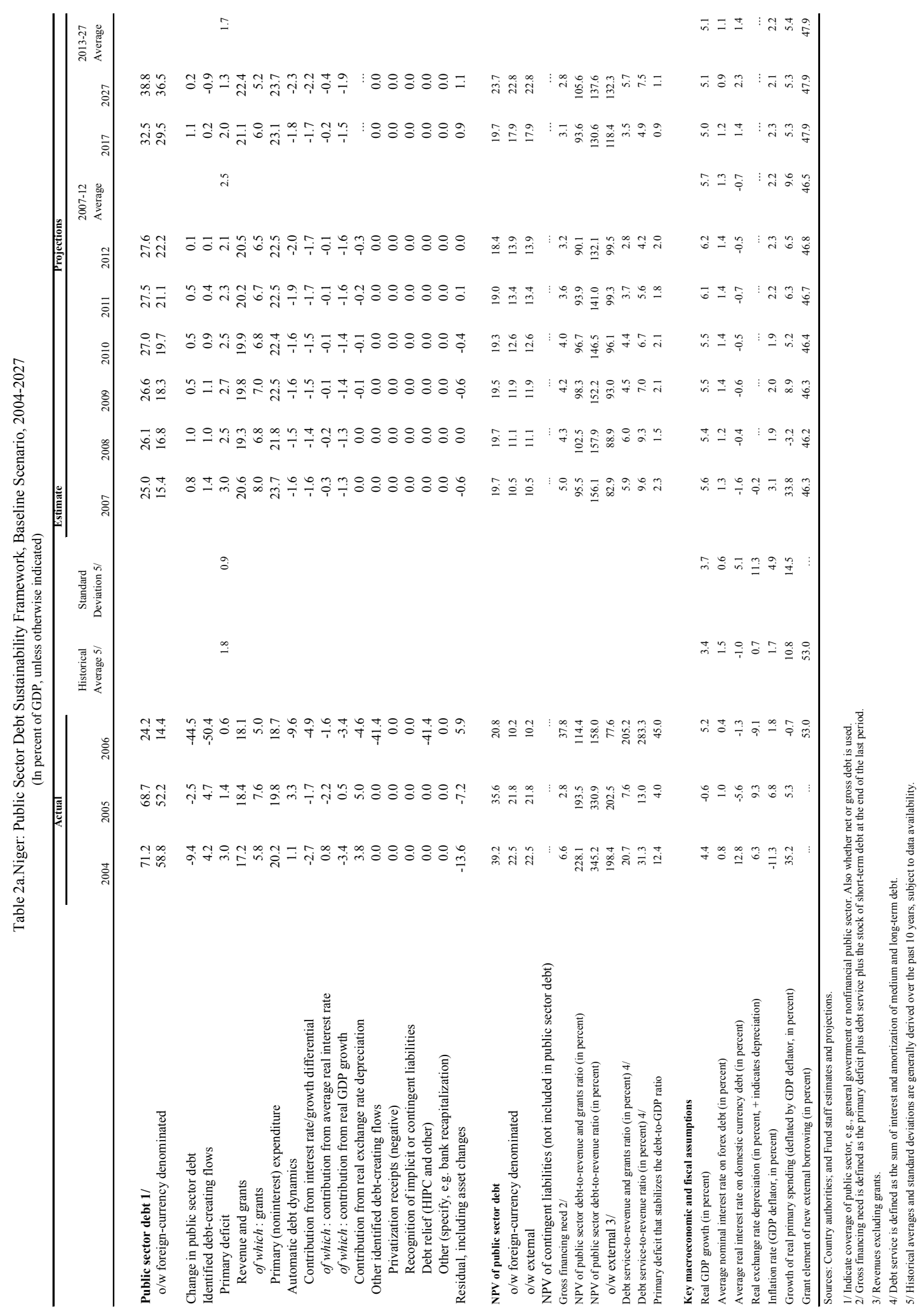


Table 2b.Niger: Sensitivity Analysis for Key Indicators of Public Debt 2007-2027

\begin{tabular}{|c|c|c|c|c|c|c|c|c|}
\hline & \multicolumn{8}{|c|}{ Projections } \\
\hline & 2007 & 2008 & 2009 & 2010 & 2011 & 2012 & 2017 & 2027 \\
\hline & \multicolumn{8}{|c|}{ NPV of Debt-to-GDP Ratio } \\
\hline Baseline & 20 & 20 & 19 & 19 & 19 & 18 & 20 & 24 \\
\hline \multicolumn{9}{|l|}{ A. Alternative scenarios } \\
\hline A1. Real GDP growth and primary balance are at historical averages & 20 & 20 & 19 & 19 & 19 & 18 & 20 & 29 \\
\hline A2. Primary balance is unchanged from 2007 & 20 & 20 & 20 & 20 & 20 & 19 & 22 & 31 \\
\hline A3. Permanently lower GDP growth $1 /$ & 20 & 20 & 20 & 20 & 20 & 20 & 25 & 41 \\
\hline \multicolumn{9}{|l|}{ B. Bound tests } \\
\hline B1. Real GDP growth is at historical average minus one standard deviations in 2008-2009 & 20 & 21 & 23 & 24 & 24 & 24 & 30 & 40 \\
\hline B2. Primary balance is at historical average minus one standard deviations in 2008-2009 & 20 & 20 & 19 & 19 & 19 & 18 & 20 & 24 \\
\hline B3. Combination of B1-B2 using one half standard deviation shocks & 20 & 20 & 20 & 20 & 19 & 18 & 18 & 21 \\
\hline B4. One-time 30 percent real depreciation in 2008 & 20 & 23 & 22 & 21 & 20 & 19 & 18 & 20 \\
\hline \multirow[t]{2}{*}{ B5. 10 percent of GDP increase in other debt-creating flows in 2008} & 20 & 26 & 25 & 24 & 24 & 23 & 23 & 26 \\
\hline & \multicolumn{8}{|c|}{ NPV of Debt-to-Revenue Ratio 2/ } \\
\hline Baseline & 95 & 102 & 98 & 97 & 94 & 90 & 94 & 106 \\
\hline \multicolumn{9}{|l|}{ A. Alternative scenarios } \\
\hline A1. Real GDP growth and primary balance are at historical averages & 95 & 101 & 95 & 93 & 90 & 87 & 91 & 119 \\
\hline A2. Primary balance is unchanged from 2007 & 95 & 103 & 99 & 98 & 97 & 95 & 107 & 140 \\
\hline A3. Permanently lower GDP growth $1 /$ & 95 & 103 & 100 & 100 & 99 & 97 & 114 & 175 \\
\hline \multicolumn{9}{|l|}{ B. Bound tests } \\
\hline B1. Real GDP growth is at historical average minus one standard deviations in 2008-2009 & 95 & 108 & 112 & 114 & 115 & 114 & 136 & 176 \\
\hline B2. Primary balance is at historical average minus one standard deviations in 2008-2009 & 95 & 102 & 98 & 97 & 94 & 90 & 94 & 106 \\
\hline B3. Combination of B1-B2 using one half standard deviation shocks & 95 & 103 & 100 & 96 & 92 & 87 & 85 & 92 \\
\hline B4. One-time 30 percent real depreciation in 2008 & 95 & 121 & 113 & 108 & 101 & 94 & 85 & 88 \\
\hline \multirow[t]{2}{*}{ B5. 10 percent of GDP increase in other debt-creating flows in 2008} & 95 & 134 & 125 & 122 & 117 & 112 & 111 & 115 \\
\hline & \multicolumn{8}{|c|}{ Debt Service-to-Revenue Ratio 2/ } \\
\hline Baseline & 5.9 & 6.0 & 4.5 & 4.4 & 3.7 & 2.8 & 3.5 & 5.7 \\
\hline \multicolumn{9}{|l|}{ A. Alternative scenarios } \\
\hline A1. Real GDP growth and primary balance are at historical averages & 5.9 & 6.1 & 4.5 & 4.5 & 3.7 & 2.8 & 3.6 & 6.5 \\
\hline A2. Primary balance is unchanged from 2007 & 5.9 & 6.0 & 4.5 & 4.5 & 3.8 & 2.9 & 3.8 & 6.9 \\
\hline A3. Permanently lower GDP growth $1 /$ & 5.9 & 6.0 & 4.6 & 4.5 & 3.8 & 3.0 & 4.0 & 8.2 \\
\hline \multicolumn{9}{|l|}{ B. Bound tests } \\
\hline B1. Real GDP growth is at historical average minus one standard deviations in 2008-2009 & 5.9 & 6.2 & 4.9 & 5.0 & 4.3 & 3.4 & 4.6 & 8.6 \\
\hline B2. Primary balance is at historical average minus one standard deviations in 2008-2009 & 5.9 & 6.0 & 4.5 & 4.4 & 3.7 & 2.8 & 3.5 & 5.7 \\
\hline B3. Combination of B1-B2 using one half standard deviation shocks & 5.9 & 6.2 & 4.7 & 4.6 & 3.8 & 2.8 & 3.4 & 5.2 \\
\hline B4. One-time 30 percent real depreciation in 2008 & 5.9 & 6.2 & 5.0 & 5.0 & 4.3 & 3.4 & 4.2 & 6.5 \\
\hline B5. 10 percent of GDP increase in other debt-creating flows in 2008 & 5.9 & 6.0 & 5.5 & 5.0 & 4.2 & 3.3 & 4.6 & 6.4 \\
\hline
\end{tabular}

Sources: Country authorities; and Fund staff estimates and projections.

1/ Assumes that real GDP growth is at baseline minus one standard deviation divided by the square root of 20 (i.e., the length of the projection period).

2/ Revenues are defined inclusive of grants. 
Figure 1. Niger: Indicators of Public- and Publicly-Guaranteed External Debt Under Alternative Scenarios, 2007-2027
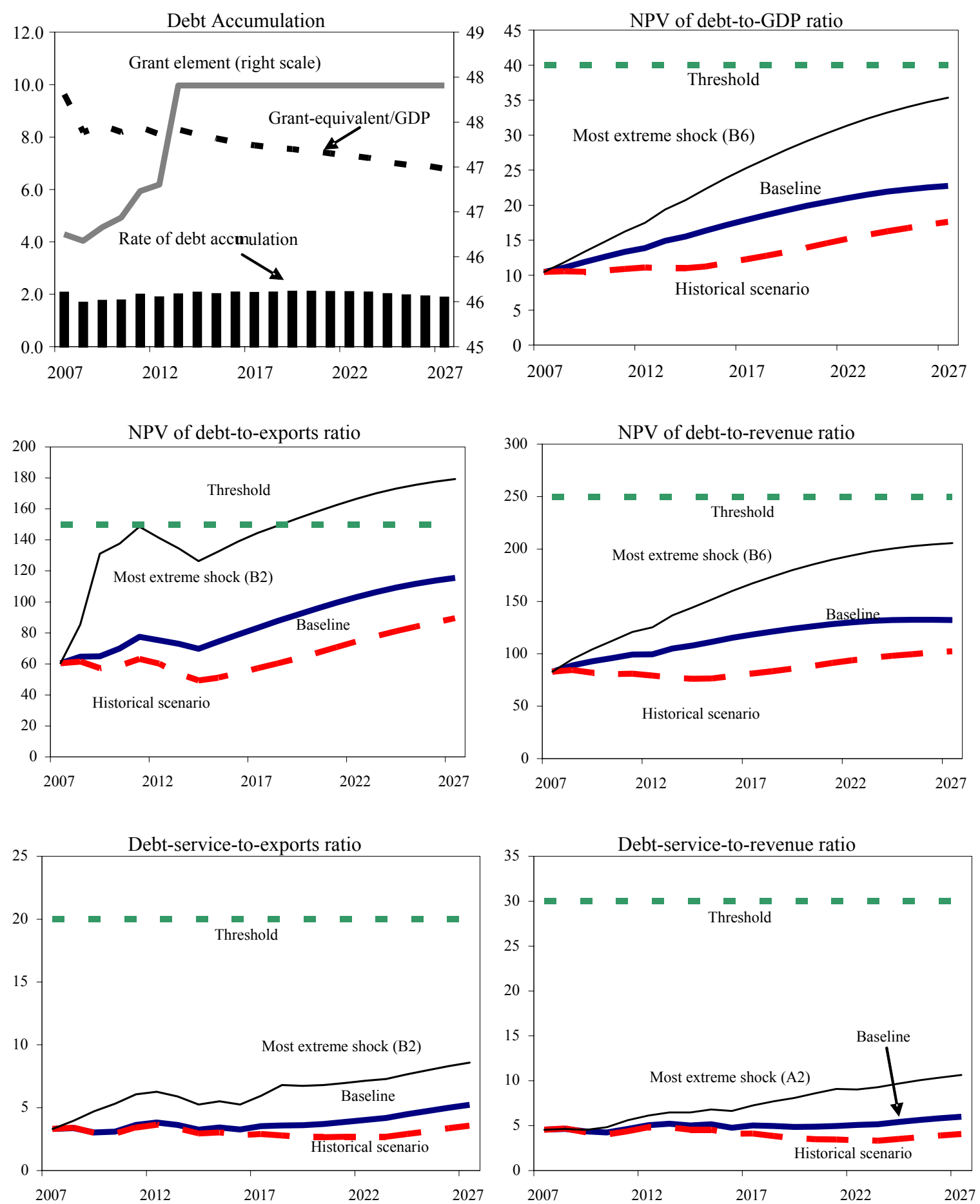

Source: Staff projections and simulations. 
Figure 2. Niger: Indicators of Public Debt Under Alternative Scenarios, 2007-2027 1/
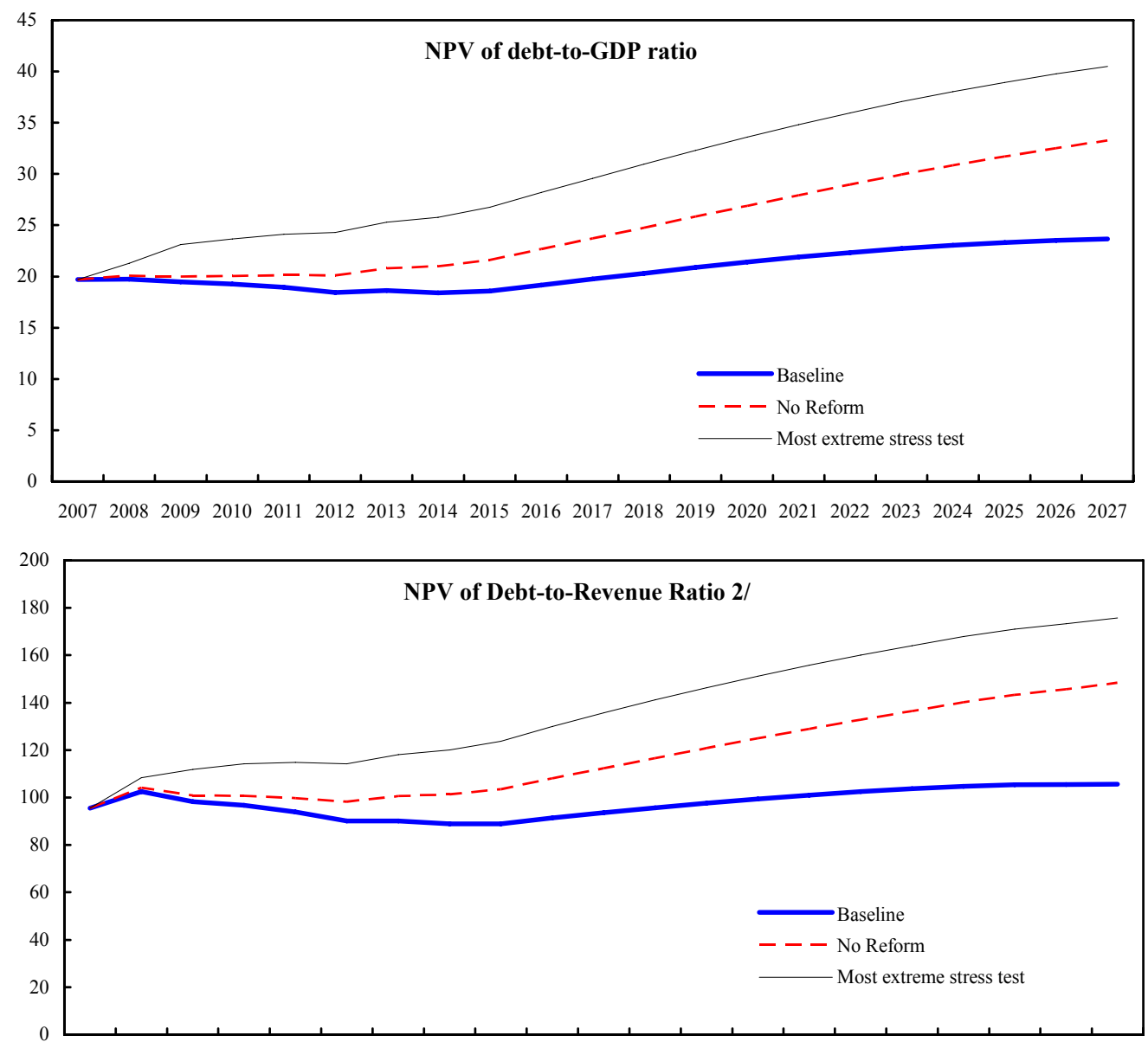

200720082009201020112012201320142015201620172018201920202021202220232024202520262027

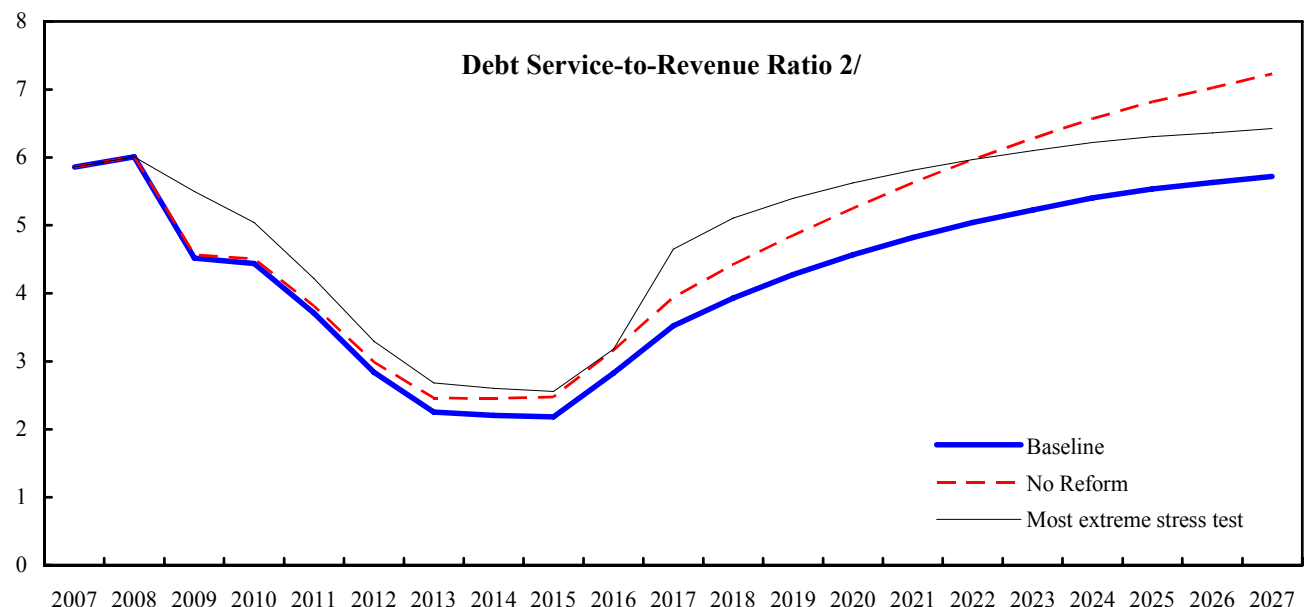

Source: Staff projections and simulations.

1/ Most extreme stress test is test that yields highest ratio in 2017 (B1 in all three graphs).

2 / Revenue including grants. 
Press Release No. 07/273

International Monetary Fund

FOR IMMEDIATE RELEASE

Washington, D.C. 20431 USA

November 21, 2007

\section{IMF Completes Fifth Review Under the Poverty Reduction and Growth Facility with Niger and Approves US\$1.5 Million Disbursement}

The Executive Board of the International Monetary Fund (IMF) today completed the fifth review of Niger's economic performance under a three-year Poverty Reduction and Growth Facility (PRGF) arrangement. The completion of the review enables the release of an amount equivalent to SDR 940,000 (about US\$1.5 million), bringing total disbursements under the arrangement to SDR 25.38 million (about US\$40.4 million).

In completing the review, the Executive Board approved Niger's request for a waiver for the nonobservance of a continuous structural performance criterion on the application of the flexible pricing mechanism for petroleum products. The Board also approved Niger's requests for the modification of the quantitative performance criterion for end-December on domestic financing of the government, the modification of the structural performance criterion on the application of a flexible mechanism for petroleum pricing, and the elimination of the structural performance criterion for end-December on the adoption of a decree defining the modalities for reimbursing the frozen postal savings accounts of the former National Postal Savings Office over a two-year period.

The Executive Board also extended Niger's PRGF arrangement by four months to May 31, 2008.

Niger's PRGF arrangement was originally approved on January 31, 2005 in an amount equivalent to SDR 6.58 million (see Press Release No. 05/20) and augmented to SDR 26.32 million (about US\$41.9 million) on November 14, 2005 (see Press Release No. 05/251).

The PRGF is the IMF's concessional facility for low-income countries. PRGF-supported programs are based on country-owned poverty reduction strategies that are adopted in a participatory process involving civil society and development partners and articulated in the country's Poverty Reduction Strategy Paper. This is intended to ensure that PRGF-supported programs are consistent with a comprehensive framework for macroeconomic, structural, and 
social policies to foster growth and reduce poverty. PRGF loans carry an annual interest rate of 0.5 percent and are repayable over 10 years with a 51/2-year grace period on principal payments.

Following the IMF Executive Board discussion on Niger, Mr. Murilo Portugal, Deputy Managing Director and Acting Chair, stated:

"The Nigerien authorities are to be commended for the overall satisfactory performance under the PRGF-supported program. Economic growth in 2007 is being sustained for the third year in a row, inflation is close to zero, reflecting a good harvest, and the national cereal security stocks have been replenished. Fiscal performance to September has been stronger than programmed, due both to higher revenue and lower expenditure than projected.

"The fiscal program through end-December 2007 has been modestly revised to take into account lower external budget support than previously expected, but also higher projected revenue, boosted by exceptional revenue from mining, and somewhat higher expenditure. On the basis of these revised projections, the basic fiscal deficit target has been reduced. The fiscal program for 2007 and the proposed budget and projected expenditures for 2008 are consistent with the medium-term expenditure frameworks for increased investment in key sectors that underpin Niger's new Poverty Reduction Strategy for 2008-2012.

"The program continues to emphasize improvements in tax and customs administration through simpler procedures, as well as a widening of the tax base. Reforms in public expenditure management are ongoing, including measures to strengthen procurement, financial control, and budgetary execution. Steadfast implementation of these reforms will be essential for enhancing the effectiveness of pro-growth and pro-poor programs, advancing toward the Millennium Development Goals, and mobilizing additional resources form external donors.

"Given that Niger's external debt position remains vulnerable to adverse shocks, it will be important that the authorities sustain their efforts to preserve debt sustainability by seeking financial assistance mainly in the form of grants and on highly concessional terms.

"Continued efforts to enhance further the business and investment climate will be key to achieving a higher rate of economic growth. It will also be important that the authorities continue with the steadfast implementation of their action plan for the settlement of domestic arrears. Steps taken to restructure ailing microfinance institutions and privatize a financial institution should promote access to credit and deepen financial intermediation," Mr. Portugal said. 


\section{Statement by Laurean W. Rutayisire, Executive Director for Niger}

\section{November 21, 2007}

1. I would like to convey to the Executive Board and Management my authorities' appreciation of their support to Fund's continued involvement in Niger. I also wish to thank staff for the constructive and fruitful policy dialogue it has had with my authorities in the context of the fifth review of the three-year arrangement under the PRGF. My Nigerien authorities value the critical assistance that Fund staff has provided in the preparation of their new Accelerated Development and Poverty Reduction Strategy (DPRS) for 2008-12, notably in the formulation of a budgetary framework consistent with this strategy as well as with the medium-term fiscal framework. In support of the DPRS, the Donors Conference, held last month in Brussels pledged assistance amounting to 3.5 billion US dollars. My authorities are hopeful that they can count on the Fund's catalytic role, along with other bilateral and multilateral initiatives, to translate the donors' promises into effective, full and timely disbursements in favor of Niger.

2. The staff report provides an array of important achievements mainly reflected in the part devoted to the recent economic developments and performance under the PRGF program. This document also highlights medium-term outlook and macroeconomic objectives for 2007-08, revealing thereby the type of policies envisaged for the coming years. As in previous staff reports under the current arrangement, my authorities expressed their consent to the publication of the report on the fifth review.

\section{RECENT ECONOMIC DEVELOPMENTS AND PERFORMANCE UNDER THE PRGF PROGRAM}

3. My Nigerien authorities are determined to pursue strong growth path (above 5 percent) in order to accelerate poverty reduction. In 2007, real GDP growth should reach about 5.6 percent, owing to broad-based activities notably in the agriculture (benefiting from goods rains), mining, telecommunications, and construction sectors. Inflation remains very low, under 1 percent over the last two years. Private investment is increasing, reflecting growing external investors' interest in Niger's mining sector. The volume of investments is expected to reach 20 percent over the coming three years. My Nigerien authorities are committed to press ahead with their efforts to reduce the cost of doing business and enhance the investment climate. 
4. The basic fiscal balance at June and September 2007 improved significantly, posting an important surplus instead of projected deficit. This favorable development reflects not only the efforts made by the authorities in strengthening revenue collection but also the measures to restrain spending in order to offset possible shortfalls in external assistance.

5. As the country is exposed to frequent adverse climate conditions, my authorities continue to pay close attention to the food security situation, which has been improved significantly. Indeed, the national stock attained 65,000 tons last August. Replenishment actions aimed to reach the programmed level of 80,000 tons have been taken. Likewise, grain banks have been created. Further efforts are underway to scale up the food security reserve to 110,000 tons, deemed as being the more appropriate national security stock level.

6. The situation of the banking system is sound. The banking credit increased steadily, reflecting the positive development in the investments projects from private sectors. New banks have also contributed to the steady expansion of credit. My authorities are exploring measures to address the issue of nonperforming loans, including the lifting of the level of provisions.

7. Regarding structural reforms, my authorities continue to make important strides in the implementation of the required measures. These include current efforts to strengthening public finance management, at both the revenue (tax and customs administrations, overhauled tax code) and expenditure ends; progress made in implementing the Public Expenditure and Fiscal Management (PEMFAR); the adoption of a new mining code, as well as that of the petroleum code. As regards the business climate, progress in simplifying the procedures and reducing the costs related to the establishment of new businesses has been accomplished. In the extractive industry sector, my authorities are also cognizant of the benefits of transparency and are committed to the principles of the Extractive Industry Transparency Initiative (EITI). They have obtained in September 2007 the acceptance of Niger as an EITI candidate country.

8. Reflecting the positive achievements on the policy implementation and structural fronts, performance under the PRGF-supported program has been highly satisfactory since the previous review. Indeed, all quantitative performance criteria and all indicative criteria were met. However, one structural benchmark and one continuous performance criterion were missed. Regarding the latter criterion, the nonobservance is related to a tax deferment introduced in April 2007 in the petroleum 
pricing mechanism when it appeared quite impossible to apply the full pass-through without incurring the risk of violent social unrests, similar to those experienced in March 2005. Nevertheless, the deferred tax amount has been reduced in July and the authorities have eliminated the remaining amount on November 1, 2007. This point illustrates well the issue I raised a few weeks at the Board, pertaining to the real difficulties experienced by a number of countries in my constituency (and beyond) in the application of oil pricing full pass-through mechanism. It is important that the Fund examines more profoundly the approach to this problem taking into consideration the capacity and political economy constraints facing the individual countries.

9. While the risks of debt distress remain low, the Joint Fund-Bank Debt Sustainability Analysis underscores Niger's daunting need for external financing, which if fulfilled on concessional basis, could preserve its debt sustainability over a long run.

\section{Macroeconomic ObJectives And Policies For 2007 AND 2008}

\section{Fiscal Policy for the rest of 2007}

10. Determined to increase transparency in fiscal management and to strengthen the quality of fiscal data, my authorities have revised the 2007 budget program with the view to take into account exceptional resources amounting to1.5 percent of GDP stemming from mining permit receipts. The revised budget program also reflects the projected shortfall of 0.7 percent of GDP in external assistance. For the whole year 2007 , it is expected that the combined effects of restraining spending and increasing revenue collection, notably in the area of VAT mobilization, lead to a lower basic deficit than initially programmed.

11. Regarding the exceptional resources from mining sectors, my authorities have since May 2007 put in place a Priority Investments Fund (PIF), a budgetary framework defining clearly the modalities for the use of these resources. Expenditures related to security, rural development, infrastructure, and development support have been retained as priority areas designated to benefit from this Fund. Facing the surge of security problems in the northern part of the country, which poses serious threats to a well-functioning of democratic institutions built and consolidated in recent years, my authorities intend to use the bulk of these resources in the area of security. Recent developments indicate a real improvement in the way of bringing peace back in this region, thanks to negotiations efforts undertaken with the involvement of regional stakeholders. 
12. On the domestic arrears side, while sustained efforts led to reduce by almost half the stock between 1999 and 2006, many other actions towards the complete clearance of these arrears are underway. These include settlement of debt arrears with private sector suppliers; settlement with public utility companies which will start soon; and the unfreezing of deposits of the former National Saving Bank, which is scheduled for mid-2008.

\section{Fiscal Policy for 2008}

13. The 2008 fiscal policy will put more emphasis on the financing of the priority sectors of education, health, and rural development. While pursuing the implementation of this priority spending, my authorities intend to pay close attention to the preservation of debt sustainability.

14. On the revenue side, the ongoing measures aimed to curb tax and customs exemptions and combat evasion will be implemented steadfastly. In this vein, priority will be given to achieving electronic interconnection between the main border offices and regional customs offices, with the view to allowing more rigorous monitoring of merchandise undergoing customs clearance. On-site customs controls will be better targeted. As regard taxes, many specific actions are being adopted at the tax administration directorate, including the simplification of VAT payment procedures, the enhancement of tax supervision, the implementation of an effective system of refunding VAT credits, the establishment of an information base for real estate and taxation, and the adoption of a new software program which will be more effective for tax collection registration.

15. In this context, my Nigerien authorities expect that the basic fiscal deficit will decline from 3.6 percent of GDP in 2007 to 2.8 percent in 2008.

\section{Structural Reforms}

16. My Nigerien authorities are fully aware of the critical role that structural reforms will play in the attainment of their main macroeconomic objectives; in particular those related to the achievement of a growth rate of at least 7 percent consistent with the aim of improving social indicators and meeting the MDGs.

17. In the area of public management, my authorities' resolve is focused on further strengthening domestic revenue collection, through a set of tax and customs 
administration measures which will be implemented steadfastly. Moreover, ongoing efforts to strengthen financial controls and supervision will be continued, notably by expanding and streamlining the general directorate for the control of government procurement.

18. As regards the financial sector, the authorities have launched the call for tenders for the privatization ofCrédit du Niger. Steps undertaken in the restructuring of the financial branch of post office and microfinance institutions will be pursued in 2008. Due to the need to ensure the soundness of the new institution that will take over the financial activities of the post office, which requires injection of fresh public funds, the start of operations for this structure is expected for mid-2008. This is the reason why my authorities are requesting to remove the performance criterion related to the payment of frozen deposits by end-December 2007.

19. As evidenced by the new position of Niger in the World Bank's Doing Business 2007 report, which ranked it 160 out of 175 countries against 170 in 2005 , important efforts were made and continue to be accomplished in the way to improving the business climate. The most visible efforts include the simplification of procedures within the two employment agencies and the reduction and deferment of costs of registration or starting business.

\section{Medium-Term ProspeCts AND The PRSP}

20. Based on Niger's favorable achievements and bright economic prospects, reflecting the increasing investment opportunities in the mining sector, my authorities undertook and finalized the revision of their poverty reduction strategy which is now more focused on growth acceleration and the attainment of MDGs. The new strategy for 2008-2012 was built on four pillars, namely preserving macroeconomic stability, boosting public investment in human capital and physical infrastructure, strengthening economic governance, and developing the private sector. Drawing lessons from the unpredictability of aid as experienced in recent years, my Nigerien authorities have adopted a prudent and flexible approach, based on the elaboration of three scenarios of growth with linkages to different levels of expenditures which in turn depend on the degree of resources mobilization. In this approach, the first scenario called "baseline scenario" underpins the staff medium-term current framework. The second scenario envisages an increase of expenditures of about 20 percent compared to the first one. The third and last scenario ("MDG scenario"), which is the most optimistic of all, envisions an increase of expenditure amounting to 86 percent with respect to that set out in scenario one. It is expected that this last scenario leads to an average growth rate of not less than 7 percent over the period 
2008-2012 against a growth rate of about 6 percent in the second (intermediate) scenario.

21. In terms of the resources needed to finance all the specific programs comprised in the revised strategy, the amount of 3.5 billions US dollars pledged by donors during their round-table held on October 25-26, 2007 appears to be more consistent with the intermediate scenario described above. It is, therefore, far from what is needed to incline the trend of social indicators in a way to attain the MDGs. My authorities intend to intensify their efforts to mobilize internal resources while seeking a more appropriate way to elicit other development partners' interests, namely those who have not yet announced their financial intention to support Niger's new growth and poverty reduction strategy. Strong bilateral actions are needed to close the resource gap, and my authorities have strongly engaged in reaching a positive outcome.

22. In view of the current trend and unpredictability in aid flows, the assumption made by some analysts that very few African countries could attain the MDGs by 2015 is likely to come true if concerted efforts towards fulfilling the promises made under the Monterrey Consensus are not undertaken. In this regard, we strongly urge the Fund to keep take up its part of responsibilities, especially by putting more emphasis on its catalytic role in favor of countries like Niger which have made impressive efforts towards macroeconomic stabilization and reform implementation but still faces stringent constraints to finance their development and poverty reduction efforts.

\section{CONCLUSION}

23. My Nigerien authorities have shown firm commitment to sound macroeconomic policies and reforms, as evidenced by the satisfactory implementation of the current PRGF-supported program, as well as the important accomplishments made so far in the finalization of the new PRSP and the achievement of an average annual growth rate beyond 5 percent since 2005. My authorities believe that an adequate response to boost growth requires the firm implementation of the new PRSP, which supposes maintaining macroeconomic stability, strengthening domestic revenue collection, pursuing efforts to diversify production, executing priority programs, and enhancing the business environment.

24. Maintaining a sustainable debt position while seeking additional financing needed to carry out their PRSP and make progress towards the MDGs remains a 
serious challenge for my Nigerien authorities. More predictable and timely donor support is required to meeting the country's economic and developmental goals without endangering its debt sustainability. In this regard, the authorities rely on the continuous support of the Fund, in particular through its catalytic role in mobilizing development partners' assistance. On their part, my authorities remain committed to pursuing a prudent external debt strategy in the post-MDRI era. They will continue to aim at contracting debt only with a grant element of at least 50 percent in 2007 and beyond. As for the management of existing debt, they continue to aim at prudent strategy, consisting of building capacity to develop a medium-term debt strategy and to analyze debt sustainability, while still striving to maintain dialogue with remaining non-Paris Club creditors, with the view to benefiting from debt relief on terms comparable to those already obtained.

25. Based on their demonstrated track record of policy and reform implementation, including in undertaking corrective actions when necessary, I would like to ask Directors' support for my authorities' request for waiver and modification of performance criteria and the completion of the fifth review under the PRGF arrangement. I also call on the Board to grant Niger an extension of the current arrangement to May 31, 2008 instead of January31, 2008, to allow for the completion of the sixth and final review on the basis of the December 2007 test date. 